\title{
SER MÃE: NARRATIVAS DE HOJE
}

\section{Kimy Otsuka Stasevskas}

Dissertação de Mestrado apresentada à Faculdade de Saúde Pública, Universidade de São Paulo - USP Área de Concentração: Saúde Materno-Infantil Orientadora: Prof ${ }^{a}$ Associada Néia Schor

São Paulo 
À minha mãe, Ayame, que me fez compreender que poderíamos decidir e encaminhar nosso relacionamento sem o imperativo consangüíneo, simplesmente pelo fato de sermos duas pessoas. À minha filha, Rita, que desejo sinceramente, pela pessoa que é, compartilhar sempre de sua amizade. 


\section{AGRADECIMENTOS}

Gostaria de agradecer à minha professora e orientadora, Néia Schor, não só pelo acompanhamento e auxílio dado ao trabalho, como também por sua generosidade e estímulo na minha formação como pesquisadora.

Agradeço à professora Keiko Ogura Buralli pela bibliografia, pelas valiosas indicações e também pela ajuda e incentivo que deu para o meu ingresso no mestrado.

À Professora Márcia Nozawa, pelas observações e sugestões que muito contribuíram para a melhoria do trabalho.

Aos professores do Departamento, Prof. Cornélio Pedroso Rosemburg, Prof ${ }^{\mathrm{a}}$. Ana Cristina d'Andretta Tanaka, Prof ${ }^{\mathrm{a}}$. Augusta Thereza de Alvarenga, Prof. Alberto Advíncula Reis e Prof ${ }^{a}$. Fumika Peres, a quem sempre que houve necessidade recorri e fui extremamente bem atendida.

Aos funcionários do departamento, Elba, Nilson, Yara, Leandro, Marizilda, Soninha e Sônia pelas reais colaborações e paciência.

Agradeço também à minha família, Yanina, Marilena, Alexandre, Lélia e meus sobrinhos, Laura, Artur, Talita, Tamires, Zenon e lara pelo carinho e afeição que têm por mim, sem o qual não sou capaz de nada.

Tenho um especial agradecimento ao Kuja, meu companheiro, por todo apoio logístico e pela inabalável confiança que possui em minhas capacidades intelectuais o que, muitas vezes, serviu-me de revigoramento.

À memória de meu pai, prof. Zenonas Stasevskas, que me transmitiu o desejo de conhecer. 
À memória de minha mãe, Ayame, e à minha filha Rita, por me fazerem filha e mãe, dedico-lhes meu trabalho.

Também sou grata aos meus amigos Dedé, Kátia, Paulinha e especialmente à Lucila e Patrícia, por serem amigos e cúmplices e pelas colaborações efetivas com o trabalho.

Sou grata também à Neide cujo trabalho e carinho me deu suporte e tranquilidade para tocar a pesquisa.

Agradeço também às funcionárias da creche Mãe do Salvador, em especial à Silvia e Julie, pela abertura e receptividade e por todo auxílio que prestaram.

Sou grata às mulheres que me concederam as entrevistas, sem a qual este trabalho não se realizaria.

Por fim, agradeço à CAPES e ao CNPq, pela bolsa de estudos que viabilizou financeiramente a execução deste trabalho. 
ÍNDICE

AGRADECIMENTOS

RESUMO

ABSTRACT iii

INTRODUÇÃO 1

CAPÍTULO I: PEGADAS HISTÓRICAS 11

MULHERES NA EUROPA 11

BRASIL: A CASA, OS FILHOS E O SUSTENTO 22

CAPÍTULO II: PEGADAS TEÓRICAS 40

CONVERSANDO COM ALGUNS AUTORES 40

IDENTIDADE E PSICOLOGIA 52

CAPÍTULO III: METODOLOGIA 61 PRESSUPOSTOS TEÓRICOS 61 PROCEDIMENTOS 71

SITUANDO OS SUJEITOS

CAPÍTULO IV: RESULTADOS E DISCUSSÃO: NA TRILHA DO SER $M \tilde{A} E$.

O PLENO 85

MÃE BOA, MÃE MÁ 95

MÃE SIM, ESPOSA, NÃO 104

EDUCAÇÃO 112

RESPONSABILIDADE E TRABALHO 118

UM MAU MOMENTO 126

UM BOM MOMENTO 135

TRANSFORMAÇÃO OU MANUTENÇÃO? 141

CAPÍTULO V: UMA SÍNTESE, UMA REFLEXÃO. 149 UMA SÍNTESE, UMA REFLEXÃO 149 REFERÊNCIAS BIBLIOGRÁFICAS 159 ANEXO 1 ANEXO 2 
No decorrer da história, os diversos grupos sociais sofrem valorizações, desvalorizações e transformações em seu papéis sociais. No jogo político, econômico e social, à mulher também foram designados padrões de comportamento e a maternidade é considerada, para várias culturas e por longos períodos, o principal desígnio feminino. No Brasil, interesses do Estado, da Igreja e da Ciência contribuem, desde a organização Colonial até possivelmente nossos dias, com alguns importantes fundamentos no que se entende por ser mãe. Mais recentemente, a sociedade sofreu mudanças que derivaram em uma nova inserção social para a mulher provocando um jogo de corroborações e transformações na maneira de ser mãe.

Este trabalho pretende buscar um entendimento do que se pensa sobre ser mãe, no grupo entrevistado. Uma reflexão sobre o conjunto de idéias trazido com relação à maternidade, dos elementos que o constituem, suas articulações, levando-se em consideração as influências históricosociais.

O método utilizado situa-se no âmbito da pesquisa qualitativa. Foram entrevistadas 15 jovens mães, em duas etapas de entrevista, a partir de um roteiro de perguntas abertas que buscava incentivar suas vivências enquanto mães, o sentido a isto atribuído. As narrativas indicaram os temas de reflexão deste trabalho, a saber: a eternização de ações e sentimentos, a responsabilidade na educação, as dificuldades advindas das tarefas com o 
filho e o trabalho, a família, a projeção daquilo que é visto como nocivo à relação mãe/ filho. Enfim, a meada ideológica da maternidade, interpenetrando o ser e o fazer no cotidiano desta mãe.

Podemos dizer que, tanto o desejo de ser mãe como a maneira de sêlo sofre influências muito antigas e ainda muito atuantes, o que, neste momento de transição dos papéis sociais, faz com que se crie um descompasso entre a antiga e a atual condição da mulher também no seu modo de ser mãe. 
Different social groups have been increasing and decreasing their value as well as presenting changes in their social roles, through history. In the political, economic and social game, patterns of behaviour were designated to women and the motherhood has been considered, for many cultures and for a long period, the most important feminine attribute. Since the colonial Brazilian period, State, Church and Science's interests have been providing some important ideas related to being mother. Recently, society suffered changes that for the woman mean new social status what contributes to reassuring and transforming the way of being mother.

Qualitative methods were chosen to analyse the data from this study. Fifteen young mothers were interviewed following a opened questionnaire, trying to get the women's experiences as mothers. The discourses indicate the reflection themes presented in this work: actions and feelings that were presented as eternal, the responsibility in education, the difficulties in conciliating work and child's care, family, projection of bad aspects related to mother/child relationship. Lastly, the motherhood's ideological net's influences in being and building the mother's every day life, and vice-versa.

Therefore, regarding the social roles in this transitional moment, there are old and still active ideas affecting the present woman's status as a mother in her being mother's wish and in her way of being it. 
O tema maternidade surgiu, inicialmente, quando recém - formada em psicologia pela PUC-SP, fui trabalhar na extinta Secretaria de Estado do Menor de São Paulo, como educadora de rua. Parte deste projeto envolvia visitas à família, que, na maioria das vezes, consistia em mãe e irmãos. Objetivava-se nesses casos, levantar as possibilidades de retorno do menino(a) à família, ou o restabelecimento do contato entre eles, muitas vezes perdido. Freqüentemente, por inúmeras razões, isto não era possível, ou simplesmente não procedia. A maior parte dessa população morava em favelas e uma outra parte habitava as ruas. O relacionamento destas mulheres com seus filhos (as), muitas vezes, despertou surpresa e curiosidade em mim. Nossa equipe preocupava-se em aproximar-se de uma compreensão maior sobre as famílias que eram nossa responsabilidade, e para isto discutíamos e rediscutíamos sobre o seu modo de vida. Constantemente, eu incluía nestas reuniões o assunto da maternidade, o que estas mulheres faziam para seus filhos e como o faziam. Nos víamos às voltas com considerações de todo tipo: falávamos sobre a generosidade e solidariedade que tantas e tantas vezes encontramos, de atitudes que pareciam monstruosas, outras comezinhas, mas, sobretudo, falávamos da rudeza de suas vidas. Era uma população bastante pobre, que não vivia um cotidiano ordinário em todos os aspectos, desde o que se refere a coisas muito concretas, como se alimentar e dormir, até as mais complexas como a relação e a concepção de família. 
INTRODUCÃO

Fui compreendendo que os estereótipos, os modelos, a conduta padrão das pessoas em geral, não eram facilmente adaptáveis ás condições em que estas pessoas, alvo de nosso trabalho, viviam, por vezes, em um estado quase primitivo de luta pela sobrevivência. Isso certamente forçou uma revisão constante dos meus tão assentados pontos de vista com relação a tantas coisas, como por exemplo, a possibilidade de maneiras muito diferentes de cuidar.

Mais tarde, engravidei e tive uma filha. Experimentar a maternidade trouxe muitas descobertas, parecia ter mudado a maneira como todos me viam, era como se me tivesse introduzido em uma nova confraria (bem mais tarde, quando alguma amiga tinha seu primeiro filho, eu costumava brincar dizendo à recém mãe: nasceu? Ora, bem vinda à tribo!) Ir descobrindo como me relacionar com minha filha era também ir redescobrindo como me relacionar com as pessoas de meu círculo mais íntimo como meu marido, meus irmãos, minha própria mãe, meus amigos... Mas também como me relacionar com a sociedade em geral, as pessoas no trabalho, na escola ou na escola da filha, a partir de uma posição um pouco distinta da posição anterior, ou talvez muito distinta da posição anterior: sendo mãe. Muitos ganhos e muitas perdas, como qualquer transição significativa. $O$ que me intrigava então, era o fato de não existir, muitas vezes, espaço ou tempo, para uma reflexão e um redimensionamento das tarefas ou das prioridades de minha vida. Freqüentemente, e principalmente no início, no primeiro ano 
de vida de minha filha, urgia a necessidade de cuidados, você sabe, disto depende a vida do bebê. Não há como mudar toda uma rotina do dia a dia de forma hábil e rápida, para, por exemplo rediscutir quem vai dar esta mamadeira (fora as outras mamadeiras e a infinidade de tarefas que consiste o cuidar de um bebê), vai-se pensando nisto enquanto faz. Mas, aí surgia a pergunta, porque eu tenho que pensar nisto e tenho que pensar enquanto faço? Porque não é a avó, ou o tio, ou a vizinha que pensa nisso enquanto faz? Ou seja, que sou eu quem devo fazer parece dado, que é a mãe quem cuida, é o óbvio.

Fato é que ao mesmo tempo que me sentia profundamente inserida na condição de mãe, curiosamente observava esta condição, isto gerava conflitos, uma vez que nem sempre simplesmente aceitava algo que derivado da condição de mãe. Me perguntava porque é que a conduta padrão era simplesmente aceitar.

Com o passar do tempo e, folgo em dizer, neste caso ele conta ao nosso favor, a maternidade não mais parecia um furacão que vinha tirar da minha vida meu próprio lugar e algo que aprendi com minha mãe, no papel de filha, começava a ter novo sentido para mim, agora que também era mãe. Primeiro esta palavra: também, eu também era mãe, e não apenas, ou mesmo, principalmente, mãe. Isto pode parecer simplista e ingênuo, mas ajudou a tranformar a maneira de encarar a minha maternidade, menos presa às exigências (e são muitas) que giram em torno do ser e do fazer de 
uma mãe e aproveitando mais a relação. Muitas vezes sendo muito mais simplesmente pessoa e muito menos uma mãe.

Esta vivência reascendeu inquietudes e dúvidas que, sob novos contrastes, somaram-se às antigas reflexões, aos antigos questionamentos e que dão origem a este trabalho: existem maneiras diferentes de ser mãe? Existe uma mudança na maneira de ser mãe? Se há, que tipo de transformação está ocorrendo no modo de ser mãe? As mudanças e permanências na ordem existente, interferem na maneira de ser mãe? Qual é a dimensão de ser mãe nos dias de hoje, considerando toda uma conjuntura social? Há ambivalências e/ou conflitos que a modernidade provoca na construção do modo de ser mãe? Em que isso muda ou interfere na construção de uma identidade feminina?

Há pouco tempo atrás, digamos nos anos 50-60, o Brasil vivia um contexto de grande transição. As mulheres têm interrogados, interferidos e mudados os seus papéis, a sua condição mesma enquanto mulher e a representação que dela se faz. Ao mesmo tempo, essas mudanças são acompanhadas por uma pressão normativa que tende a impor os antigos modelos de pensamento e comportamento. Os elementos histórico-sociais, para dar apenas um dos enfoques, se relacionam entre si e, evidentemente, a influência das mudanças que ocorrem em um dado momento, numa dada sociedade, atinge a todos os indivíduos desta sociedade. É importante dizer que não é propósito deste trabalho dissecar e desfiar a história da mulher, 
seu trabalho, sua posição na família, e principalmente seu papel de mãe, para desfilar, militantemente, as discriminações, sofrimentos ou preconceitos. É verdade, a mulher em sua história viveu e reviveu estas circunstâncias, entretanto, não é consideração aqui sabê-las maiores ou menores que para outros grupos sociais, tais como os homens, os portadores de deficiências ou as crianças. Entendemos que todos estão envolvidos pelo jogo histórico, social e econômico que impõe valorizações e desvalorizações e que, sobretudo, designa lugares, funções e papéis.

Mas, é fato, que a imagem da mulher, historicamente, nunca sofreu tantas mutações como nas três últimas décadas, e nesta tensão social, psicológica e histórica, acontece também um jogo de construção e desconstrução da maternidade, que é do que tentará tratar este trabalho. Não há portanto, meio de se pensar a maternidade sem pensar o lugar da mulher nesta sociedade, em que se inseriu e foi inserida, em um contexto que outrora dizia respeito essencialmente ao universo masculino, no que tange à educação, participação econômica, direito de voto, contracepção etc. Muito embora, segundo VERUCCI (1986), o incremento da participação da mulher na sociedade e sua economia, intensificado desde o fim da segunda grande guerra, é bastante localizado nas chamadas bases da pirâmide, seja esta de poder político, poder de decisão, financeira ou escolar, entre outros. 
Simultaneamente a essa inserção da mulher, mais socialmente participante, todos esperam da mãe, as responsabilidades e cuidados com o(s) filho(s), com a dedicação e disponibilidade de épocas anteriores.

Se, por um lado, possivelmente já não se espera como fato comum e corriqueiro que uma jovem tenha como perspectiva unicamente casar, ou simplesmente ter filhos e deles cuidar, por outro lado, as considerações a propósito das funções da mulher como geradora e mantenedora do lar e filhos são, como sabemos, extremamente antigas e passam não apenas de mães para filhas, como reverberam de forma geral na nossa sociedade.

Sob bases biológicas como a concepção, gravidez, gestação, parto e amamentação, a maternidade foi considerada por diversas culturas e por longos períodos, como sendo a prova natural e cabal de que à mulher cabe a principal responsabilidade pelo cuidado de crianças dentro e fora das famílias, que é exatamente isto que desejam, que nisso está depositado seu maior prazer, e que é aí que obterão seus êxitos.

Existe, muitas vezes, uma sutil confusão: "(....) ao associar os encargos maternos aos processos biológicos inerentes ao fenômeno da reprodução (....)" (NOVELINO 1988, p. 26).

Junto à essa idéia de que o destino maior para uma mulher é ser mãe, soma-se a idéia de que a mulher só será verdadeiramente feliz, plenamente realizada, sendo uma boa mãe. E, ademais, para ser uma boa mãe basta deixar fluir seu imenso amor, isento de todas emoções negativas: 
“(....) a mãe deve ser alegre, feliz, tranqüila, serena, ajustada, sem hostilidades, angústias ou conflitos - conscientes e inconscientes -, atenta às mínimas inquietações que a afligem, para saná-las imediatamente. Só assim terá condições de compreender e adequar-se às diversas etapas do desenvolvimento físico e psicológico do filho." (NOVELINO 1988, p. 28).

O papel da atividade materna adquire então, significação ideológica e psicológica, de acordo com o momento histórico e social, e estas significações, no Brasil, tiveram a contribuição da ciência e da religião, que lançavam e reforçavam pressupostos subjacentes a interesses sociais, econômicos, religiosos e políticos.

Muitos discursos sobre o padrão ideal de comportamento eram importados, por este motivo o capítulo inicial trata da Europa, mais especificamente da Revolução Francesa, e, de como a partir da redefinição entre o público e o privado, relegou-se às mulheres o espaço privado, ou seja, o lugar da esposa, mãe e dona de casa. Postula-se a existência de uma natureza feminina cujo lugar social era exclusivamente o mundo privado.

No Brasil, durante o período Colonial, criou-se um panorama próprio, característico: a população brasileira, bastante heterogênea, traz heranças, práticas culturais e representações simbólicas, e nem sempre cedeu às investidas de uma elite normalizadora, que estava seriamente preocupada 
em definir fronteiras, papéis, espaços e controlar o poder civilizador da maternidade.

No capítulo Pegadas Históricas, tentaremos apresentar um breve panorama social, econômico e cultural, e a dimensão destas transformações no plano da vida cotidiana, principalmente das mulheres. A seguir, o capítulo Pegadas Teóricas, traz o importante diálogo com pesquisadores das áreas de Ciências Sociais, Filosofia, Psicologia e História, na tentativa de um maior entendimento dessa movimentação histórica, além da busca do fio da meada ideológica da maternidade. No capítulo Identidade e Psicologia, tratamos do aspecto psíquico da formação do ser mãe. Para a compreensão dos sujeitos deste trabalho, no seu entendimento da maternidade, adotamos o conceito de identidade formulado por ERIKSON (1976), que o pensa sob uma perspectiva histórica, levando em conta o contexto sócio-cultural.

Um dos processos por onde se dá a constituição da personalidade, incluindo aí a construção do ser mãe, é a identificação, entendida na concepção psicanalítica, segundo LAPLANCHE \& PONTALIS (1967), como o processo pelo qual um indivíduo assimila um aspecto, uma propriedade, um atributo do outro e se transforma, total ou parcialmente, segundo o modelo dessa pessoa.

Podemos dizer que a construção da identidade possui, em princípio, um apoio na relação mãe/filho e, no caso das mulheres, há a identificação 
com a mãe, enquanto mãe, fornecendo suporte para um sentido da maternidade.

Por outro lado, "(....) a construção da identidade e da individualidade constitui-se como um processo elaborado ao longo da trajetória de vida, em suas práticas cotidianas a partir do modo como os indivíduos lidam com oportunidades e limites historicamente configurados“ (VAITSMAN, 1994 p.122).

Entendemos que há forte vinculação entre o significado de ser mulher e de ser mãe, e que isto faz parte do senso comum em nossa sociedade. $A$ maior expectativa dirigida à mulher ainda é a de que seja mãe, e, em contrapartida, a mulher parece precisar ser mãe para poder se sentir "mais" mulher. Muitas vezes, essas idéias são manifestadas em tom de tanta obviedade que interpõem-se a qualquer reflexão à respeito. Consideramos que pensar na difusão destas idéias é uma tentativa de desvelamento de aspectos ideológicos de uma realidade social.

A construção da identidade feminina e a maternidade se unem de tal forma que possivelmente a primeira tem fundamental apoio na segunda, o que leva a pensar que se, sob certos aspectos, a maternidade hoje pode ser opcional, deixa dúvidas sobre a forma e a qualidade desta opção, pelo fato de se constituir um dos componentes centrais na formação da identidade feminina. Abrir mão da maternidade pode significar abrir mão de parte importante, se não crucial, da própria identidade. 
Desta forma, este estudo tenta compreender, a visão da maternidade no grupo de mães entrevistado. Qual é o entendimento sobre ser mãe destas mulheres, levando-se em conta que a sociedade é marcada pelos diferentes tempos históricos e estes, por sua vez, influenciam os significados da maternidade. 


\section{MULHERES NA EUROPA}

Para compreendermos parte do ideário que posteriormente também contribuirá para indicar comportamentos e desejos da mulher brasileira, retrocederemos um pouco na história.

A Revolução Francesa, é sabido, tinha como principal eixo a definição, ou as redefinições, das fronteiras entre o público o privado. Ocorre uma invasão da autoridade pública até âmbitos mais particulares, como a família, acarretando uma politização da vida cotidiana e conseqüente ampliação do espaço público. A exigência de maior transparência nas atitudes e nos sentimentos, tendo como norte nobres princípios morais e políticos denota a ativa participação da coisa pública na vida privada. Questões pessoais eram consideradas irrelevantes senão mesmo uma afronta e pensava-se que o indivíduo deveria realizar uma revolução pessoal, reflexo daquela que se realizava no Estado. "Os revolucionários se empenharam em traçar a distinção entre o público e o privado. Nada que fosse particular (e todos os interesses eram particulares por definição) deveria prejudicar a vontade geral da nova nação.“(HUNT 1991, p. 21)

São estas definições e redefinições da vida privada, sob o foco do público e que, de certa forma, vai aos poucos: “(....) preparando o movimento romântico do fechamento do indivíduo sobre si mesmo e da dedicação à 
família, num espaço doméstico determinado com uma maior precisão". (HUNT 1991, p.21).

Esta politização da vida privada, pressupondo uma revolução individual que ecoa da estatal, pode ser observada pela maneira como foram usados símbolos pertencentes à vida familiar e doméstica com o objetivo de exercer um efeito político e, portanto, público como por exemplo, a deusa romana da liberdade, transformada em Marianne, como eram chamadas as representações do emblema da República que, não raras vezes, assumia o aspecto de uma jovem donzela ou de uma jovem mãe. "A mulher e a mãe tão desprovidas de qualquer direito político, foram capazes, apesar disso (ou justamente por isso?), de se converter nos emblemas da nova República" (HUNT 1991, p.31).

Todos esses reflexos da revolução na vida privada coloca para a Igreja católica a incômoda questão da fragilização de seus domínios e uma resistência em abrir mão do controle da esfera privada para o Estado. Surge uma nova estrutura de prática religiosa apoiada principalmente em fazeres femininos, quando as mulheres viriam a ser os pilares da Igreja e os homens se tornariam, na melhor das hipóteses, praticantes esporádicos.

A Igreja católica, bastante conservadora, pregou e prega, entre outras coisas, a inflexibilidade em assuntos que se referem a todo o tipo de contracepção. 
Todos estes aspectos criaram uma tendência no final do século XVIII de situar a mulher, devido à sua natureza, no espaço privado e esta tendência, vale dizer, se mantém como referência em tempos posteriores. A fraqueza física, intelectual e o componente emocional eram apontados como elementos genuinamente femininos, perfeitos para a criação dos filhos.

Também na Inglaterra do início do século XIX, os evangélicos acreditavam e pregavam que cabia à mulher, por imposição da natureza e portanto divina, as tarefas esponsais e maternais, ou seja, o mundo privado. Apesar da estrita submissão ao marido, havia o reconhecimento de certos dons que Ihes eram exclusivos. "Elas tinham o poder de influenciar os homens de maneira que eles as escutavam, levavam seus conselhos em consideração, ponderavam seus comentários" (HALL 1991,p.60).

Com esta mentalidade marcada pelas religiões, costumes e relações sociais, ainda na Inglaterra do começo do século XIX, os homens da burguesia experimentavam um franco progresso em seus negócios. Proliferando no comércio, as pequenas lojas continham lares em suas extensões, abrigando a família do comerciante, sendo que apenas os mais ricos dispunham de uma residência separada da empresa. Apesar de não possuírem nenhum aprendizado que as capacitasse em tarefas fora da casa, muitas esposas partilhavam com seus maridos as responsabilidades nos negócios. No comércio, somente os burgueses ricos podiam se dar ao luxo de terem esposas que não trabalhavam. Para além destas 
responsabilidades, cabia-lhes administrar a casa e educar os filhos, particularmente as filhas, uma vez que os meninos, seguindo os passos paternos, assumiam status de aprendizes, muitas vezes em outras cidades.

Contudo, esta participação na vida comercial não incluía nenhum poder jurídico, exceto nos casos de algumas solteiras e viúvas.

As mudanças nas atividades comerciais trazem um contínuo incremento da indústria e do comércio, e às mulheres não era dado possuir o conhecimento necessário para o acompanhamento e participação destas novas práticas de negócios. As escolas se dirigiam apenas aos rapazes, e às moças eram destinadas a educação em casa, isso mantinha para as mulheres cada vez mais difícil o acesso ao mundo público.

Com tal desenvolvimento comercial, os lares começam a não mais fazerem parte das lojas. O surgimento de bancos, das bolsas de valores, das grandes lojas, começam a demarcar as chamadas zonas comerciais, lugar de supremacia masculina, separando-as das eclodentes zonas residenciais, este último sim, lugar reservado para as mulheres de bem. "Essa divisão entre mundo masculino e mundo feminino apresentava uma conotação religiosa: a esfera do público era tida como perigosa e amoral" (HALL 1991, p.70). É então que surge, através do recenseamento, a categoria "mulheres do lar", de acordo com os ideais burgueses de meados do século XIX.

Sob a influência destes ideais, para uma família burguesa, a esposa e mãe era a "senhora do lar", já para os proletários a importância maior 
situava-se na praticidade e destreza na administração da economia doméstica, além da total responsabilidade com os filhos: "Enfim, o filho, sua saúde são invocados como fundamento dos deveres e poderes das mulheres" (PERROT 1991, p.142) .

Para os operários, as suas mulheres não deveriam ser iguais em tudo às mulheres burguesas: “(....) esposas e mães da classe operária deviam ser, acima de tudo, boas donas de casa de qualidades práticas". (HALL 1991, p.76).

Mas, em meio as tarefas domésticas, essas mulheres assumiam trabalhos que, sem valorização social e escassamente remunerado, em épocas de crise, muito contribuía com o orçamento familiar: “(....) recebe o elogio constante dos operários... transformando em qualidades 'naturais' um trabalho de perfil profissional, cúmplices inconscientes do movimento que disfarça as tarefas domésticas, apresentando-as como trabalho improdutivo" (PERROT 1991, p.111).

Diferente da "senhora do lar", a "dona de casa", bem mais pobre, não possuía necessariamente uma residência e sim um alojamento que se prestava a ser um local de encontro e lá, inúmeras eram as suas funções, entre tantas, dar a luz e cuidar das crianças, que eram em grande quantidade devido ao componente econômico que os filhos viriam a representar. Também amamentar, coisa que as burguesas delegavam à ama de leite, era para a mulher pobre uma tarefa pessoal. Enfim, tinha que 
atender a família com os "serviços de casa" que consistia em árdua sucessão de tarefas, "(....) procurar o melhor preço dos alimentos, por compra, troca ou até 'coleta'(....) preparar refeições, inclusive a 'marmita'(....) buscar água, acender fogo, cuidar da casa e principalmente das roupas de uso pessoal e de cama, mesa e banho, lavadas, reformadas, consertadas e remendadas (....) Tudo isso implica um gasto de tempo considerável, com idas e vindas" (PERROT 1991, p.144).

$\mathrm{E}$, além de tudo isto, quando possível ou necessário, prestava serviços para fora de casa que se traduziam em pequenos pagamentos.

Aos homens era dado o papel de provedor familiar, defendia-se a idéia do "salário familiar", na qual um homem poderia, supostamente, sustentar sua família condignamente. As mulheres poderiam ter um ofício, desde que este fosse extensão de sua feminilidade e sobretudo, que seu ambiente de trabalho jamais fosse misto, o que a degradaria perante os olhos da sociedade e suas religiões.

O que vemos no que tange a Europa deste período, se trata de um tremendo esforço em organizar o público e o privado, com tantos e diversos movimentos. Estas tentativas acabam focalizando os interesses sobre a família: "Mas o indivíduo está subordinado à família, que, com as corporações é um dos círculos essenciais da sociedade civil. Sem ela, o Estado só se relacionaria com coletividades inorgânicas, com multidões propícias ao despotismo, demonstrando uma evidente marca hegeliana que 
difundia a idéia de família como a garantia da moralidade natural" (PERROT 1991, p.94).

O interesse em organizar tanto a coisa pública como a privada, faz com que o foco de atenção recaia justamente sobre as crianças, os filhos de famílias.

Se por um lado, o filho é alvo do investimento afetivo, econômico, educacional, existencial da família; o filho representa para esta o futuro concreto e abstrato, o sonho de amanhã e a herança de tudo que uma família reuniu em bens e em princípios. Por outro lado, é também: “ (....) ० futuro da nação e da raça, produtor, reprodutor, cidadão e soldado do amanhã" (PERROT 1991, p.146) .

Veremos em capítulo posterior, que o filho, ou a criança, nem sempre foi rodeada de atenções, assim como o é até nossos dias, mas que esta forma de vê-la, de tratá-la, tem a ver com uma mentalidade vinculada ao senso de família e que, apesar de ter surgido muito antes, é no século XVIII que encontra a sua grande consolidação.

Se, com a primeira grande guerra a chefia da família, o trabalho profissional e até a participação na guerra propriamente dita, descortina um novo universo na vida das mulheres, o caráter provisório destas mudanças apenas corroborou-Ihes a fronteira do mundo privado, cristalizando seu papel central de mãe e dona de casa: "1914 teria podido ser o ano das 
mulheres, mas foi o ano da guerra, que veio repor cada sexo em seu lugar" (THÉBAUD 1991, p.35).

Antes da guerra vinham ocorrendo manifestações femininas, de bastante realce, onde eram discutidas questões ligadas às mulheres que almejavam conquistas políticas, como o direito ao voto. Com a eclosão do conflito, todo este movimento é suspenso e a prontidão para cooperar com seu país substitui as mobilizações que se desenhavam. Os Estados envolvidos no conflito subsidiavam de maneira morosa e parca o sustento das famílias através de suas mulheres, em função do número de filhos. Exceto pelas mulheres que assumiam os negócios de seus maridos, ou por aquelas que se alistavam, o desemprego se alastrava, mas ao contrário do previsível, a assunção das colocações vagas não se fez galopante e a fatia feminina de empregos existentes ao invés de aumentar, caiu: (....) "em Agosto de 1914, os empregos femininos no comércio e na indústria representam em França cerca de $40 \%$ dos que existiam antes da guerra, e em julho de 1915 não atingem ainda os 80\%" (THÉBAUD 1991, p.38).

Com o passar do tempo, as reservas industriais vão se escasseando e vai se fazendo cada vez mais imprescindível a demanda pelo trabalho feminino em setores tradicionalmente masculinos, mesmo assim, a mobilização das francesas continua a ser limitada, e o mundo do trabalho não é tomado pelas mulheres. 
A família, neste período, é considerada célula fundamental e a queda da natalidade estimula uma cultura em prol da mãe e da criança, não obstante a proliferação da prostituição.

Nos anos vinte, o que foi tido até então como a verdadeira vocação feminina, ser dona de casa e mãe, não parece arrefecer diante da imagem da mulher moderna, que tem uma representação na silhueta da garçonne. $\mathrm{O}$ discurso médico, que se extende sobre a educação e os cuidados infantis, assim como os aportes psicológicos, reforçam o pendor feminino estrito aos domínios do lar:

A convergência entre o ensino secular da Igreja, a valorização da feminilidade a partir do século $\mathrm{XIX}$ e os deveres que incumbem às mulheres numa sociedade em vias de medicalização conduziu, entre as duas guerras, ao triunfo do discurso sobre a mulher mãe, esposa e 'sem profissão'. Alienada pelas tarefas domésticas, confinada à casa, esta mulher é a antítese da garçonne, que, a partir dos anos 30 , cai no esquecimento. Mas entre o modelo, proposto essencialmente por homens, e a sua apropriação pelas mulheres subsiste um vasto espaço de liberdade de que estas puderam usufruir (SOHN 1991, p.119). 
De fato, as mulheres trabalham dentro e fora de casa sejam nas cidades ou nos campos, como empregadas, abrindo pequenos negócios ou prestando serviços.

Na década de sessenta ocorre o aperfeiçoamento e comercialização dos contraceptivos hormonais e dos dispositivos intra-uterinos, cotribuindo para uma mudança dos costumes e possibilitando às mulheres limitar, antecipadamente, a maternidade. "Ainda que os métodos contraceptivos 'modernos' não sejam exactamente essa 'arma absoluta' que se exaltava quando apareceram, eles não deixam de estar na origem da revolução das relações entre os sexos no que respeita à iniciativa e ao controle da concepção e, talvez, ao conjunto da vida sexual” (LEFAUCHEUR 1991, p. 489).

Pela primeira vez, o desejo de paternidade tem a necessidade de vir atrelado ao desejo de maternidade, já que as mulheres podem decidir se querem ou não um filho de determinada relação sexual, e, consequentemente, sobre o número de gravidezes que desejam.

Nos anos sessenta e setenta que se inicia o questionamento e a reflexão sobre a influência da primeira grande guerra, não só no que se refere às modificações ocorridas na sociedade como um todo, como também as influências ocorridas para a vida da mulher, considerando toda a subversão da ordem social e familiar. 
No mundo ocidental, ao final da década de 60 , inúmeras são as contestações e críticas à ordem estabelecida e aos valores burgueses e também é crescente a participação das mulheres nas várias esferas do mundo público, tudo isto vai redefinindo o sistema de relações na vida privada. Surgem diversos movimentos sociais que trazem discussões e reflexões sobre as relações na família e no trabalho, e surgem novas proposições que defendem a igualdade entre os sexos, tanto em fóruns culturais como em jurídicos. Entre tantas contestações e mudanças, também é questionada a dicotomia entre os papéis públicos e privados, atribuídos segundo gênero.

Para VAITSMAN (1994, p.36), no mundo industrializado, as mulheres: "Desafiaram a dicotomia entre público e privado, conquistaram direitos como cidadãs, constituíram-se como indivíduos. O individualismo patriarcal foi abalado e a igualdade entre homens e mulheres colocou-se como possibilidade social. Com isto explodiu o conflito entre $\mathrm{O}$ individual e $\mathrm{O}$ coletivo no casamento e na família." Estes conflitos surgem revelando movimentos, ainda sutis, de transformação social em questões relativas também à maternidade. 


\section{BRASIL: A CASA, OS FILHOSE O SUSTENTO}

Além das heranças culturais, de diversas etnias, o papel feminino é, no início da colonização brasileira, construído pelo caráter exploratório da empresa portuguesa e a tradição androcêntrica da cultura ibérica.

No Brasil Colônia, Estado, Igreja e Ciência, particularmente a medicina, ou talvez, melhor dizer, Estado e seus colaboradores, definiam os papéis sociais com objetivo de estabelecer uma ordem na sociedade colonial.

A Igreja, pregava a supremacia do homem perante a mulher e o pecado original, pretendendo assim controlar a sexualidade feminina: "O adestramento da sexualidade, como parece claro, pressupunha o desvio dos sentidos pelo respeito ao pai, depois ao marido, além de uma educação dirigida exclusivamente para os afazeres domésticos" (ARAÚJO 1997, p.49).

O pai, de meninas de 12 anos ou pouco mais, era quem decidia com quem casariam e a mãe, por sua vez, dirigia sua educação de modo a prepará-la para tal, exceto as que tinham no convento a sua vocação (o que era muitas vezes decisão do pai); às outras; cabia o ensino das primeiras letras, a lida doméstica e uma certa habilidade subjetiva que compreendia a capacitação para promover alegria e harmonia no lar. A Igreja controlava de perto, através de seus instrumentos, toda esta catequese. A menina, então, casava-se e tornava-se mãe, sendo a maternidade encarada como o ápice 
PEGADAS HISTÓRICAS

de sua vida como mulher. Fazendo associações entre as mães mundanas e a mãe de Deus, e, incentivando o culto às Nossas Senhoras, a Igreja estimulava a maternidade tão logo a donzela se casasse, maternidade esta que redimiria a prática sexual, promoveria o crescimento da família e, consequentemente, favoreceria a povoação. A mulher deveria ao casar-se, engravidar o quanto antes, para purificar seu corpo da devassidão carnal, que muitas vezes não passava de um ato sexual praticado de forma mecânica: "Doravante, ela se afastava de Eva e aproximava-se de Maria, a mulher que pariu virgem o salvador do mundo”. (ARAÚJO 1997, p.52).

A medicina endossava esta concepção que via na maternidade o desígnio natural da mulher. Formadores de conceitos, os médicos elaboravam teorias que não se restringiam ao domínio da ciência, misturavam-nas à religião e à política: "Ao estatuto biológico da mulher, estava sempre associado outro, moral e metafísico". ( DEL PRIORE 1997, p.79).

Na Europa, ocorriam progressos na forma do pensar médico quanto ao corpo feminino e, em Portugal, devido a Inquisição, estes avanços eram impedidos e patrulhados como sendo sacrílegos, o que refletia diretamente no Brasil Colônia. "Nos séculos XVI e XVII, os jesuítas, o Tribunal do Santo Ofício e a Coroa uniram-se contra qualquer nova iniciativa científica ou cultural, considerando-as todas pura heresia" (DEL PRIORE 1997, p.80). 


\section{PEGADAS HISTÓRICAS}

$\mathrm{Na}$ visão da medicina, a gestação e a maternidade eram caminho natural e único para a mulher, protegendo-a de desvios, de doenças físicas e da alma, como a melancolia e a loucura, e, ainda, resguardando-a do subjugo do Demônio que, aparentemente, possuía trânsito fácil no corpo e mente femininos.

Para entender melhor como se constituíam as famílias neste período, tomaremos de início, como referência, uma importante capitania da Província. As mulheres pobres de Minas Gerais, as negras, mestiças, forras ou escravas trabalhavam principalmente no comércio ambulante, circulando vilas e arraiais com seus tabuleiros de quitutes e, na maioria das vezes, acompanhadas de seus filhos. Este pequeno comércio que encobria, eventualmente, atividades de fuga escrava, contrabando de minério e prostituição, vai progredindo; pequenas vendas vão surgindo e, proporcionalmente, aumenta a tentativa de controle por parte das autoridades: “(....) se por um lado as autoridades temiam os encontros sociais (....) pautando-se tanto em justificativas morais quanto econômicas (....), por outro, esse mercado representava uma garantia de abastecimento estável para as populações mineiras, além de gerar recursos para as despesas administrativas na região com a cobrança de tributos" (FIGUEIREDO 1997, p.146).

Em fins do século XVIII, às mulheres pobres e forras, que, quando escravas, davam dinheiro de suas atividades a seus senhores, era cobrado 
impostos pela capitania, o que estimulou a prática da prostituição para se dar conta dos tributos que a Fazenda real exigia. Isso fez acirrar ainda mais a pobreza e o meretrício penetrou na vida familiar, muitas mães e pais promoviam a prostituição de suas filhas e muitas mulheres praticavam o comércio sexual em suas próprias casas, onde moravam com outros parentes, ou até mesmo cafetinadas por estes e por seus maridos.

A maior parte das famílias era constituída de uniões consensuais, sem a oficialização da Igreja, apesar de seus esforços para combater esta forma de relacionamento: "A família em Minas foi marcada por um conflito permanente entre os poderes da Igreja, unidos ao do Estado, versus a cultura popular" (FIGUEIREDO 1997, p.165).

Era intenção primeira do Estado e da Igreja a formação da família legítima, oficializada, contudo era comum a união de portugueses com índias e, mais tarde, frente a escassez de mulheres portuguesas, a união com mulheres de origem africana, tudo à parte de formalidades matrimoniais. Ainda assim, com vistas em normalizar os grupos sociais, ficou patente para - Estado a necessidade de formalização destas uniões, já que a Colônia considerava os mestiços representantes de uma população indisciplinada. Ficou a cargo da Igreja o ataque às formas ilegítimas de casamento e a administração da legitimidade conjugal.

Quase toda família, consensual ou não, possuía filhos, em um momento que era comum o abandono, o aborto e o falecimento. $\mathrm{O}$ batizado 
das crianças era bastante difundido, mais do que a oficialização do casamento, e para as famílias não era obstáculo nenhum batizar seu filho, ainda que seus pais fossem unidos sem a bênção da Igreja. Desta forma, o reconhecimento da filiação e o compadrio confrontavam a institucionalização e promovia uma composição familiar bastante diversa.

Na casa, à semelhança das mulheres européias, além de ser função feminina a sua administração e a criação dos filhos, havia também a participação na economia através de, entre outras coisas, o comércio e pequenos serviços.

No nordeste brasileiro, as mulheres ricas eram igualmente educadas para cuidarem do lar, serem mães e educarem seus filhos. As menos abastadas vendiam produtos artesanais ou alimentícios de sua própria manufatura para sustentar e educar os seus muitos filhos, sendo esta atividade entretanto condenada socialmente, não havia bons olhos nem para o homem, nem para a mulher, esta última ganhar dinheiro. Ocorre que, para mulheres pobres e para escravas não havia outra saída que o duro trabalho.

No sertão nordestino, pela rigidez de costumes, as moças de elite eram desde muito cedo preparadas para casarem, e se casavam muito novas, através de acordos entre famílias. A mulher pobre, ao contrário, não tinha seu casamento acertado de antemão, pois não possuía patrimônio, ou dote, mas apesar disto era comum a oficialização da união. Raramente, mas ocorria, a mulher escrava se unia a um parceiro estável ou temporário. 
PEGADAS HISTÓRICAS

"Como mulher-esposa, seu valor diante da sociedade estava diretamente ligado à 'honestidade' expressa pelo seu recato, pelo exercício de suas funções dentro do lar e pelos inúmeros filhos que daria ao marido" (FALCl 1997, p.269).

Ambas, a mulher branca e a mulher escrava, não eram consideradas co-responsáveis de uma gestação e sim, meras guardiãs da semente masculina.

No sul, eram mais numerosas as mulheres brancas e o modo de vida era bastante vinculado à pequena propriedade. O papel familiar idealizado para a mulher desta região era bastante semelhante ao existente na comunidade européia no século XVIII e início do XIX. Já em fins do século $\mathrm{XIX}$ e início do século $\mathrm{XX}$, os jornais, ao contrário do que se possa imaginar, não criavam e sim reafirmavam a melhor forma de ser mulher naqueles tempos: (....) "não criaram os modelos ideais de mulher como boas mães, virtuosas esposas e dedicadas filhas. Esses modelos já faziam parte do imaginário ocidental, podiam ser encontrados na literatura, no sermão das missas, nos textos escolares, nas tradições locais" (PEDRO 1997, p. 281).

A importância dada às mulheres se devia ao fato das mães serem consideradas e divulgadas como as criadoras e educadoras dos futuros cidadãos, portanto responsáveis pelo progresso e civilização da nação.

De uma maneira geral, as idéias predominantes na então República pertenciam a correntes liberais, entretanto, no sul, prevalecia a corrente 
positivista, que pensava ainda a mulher como um ser de natureza complementar ao homem, divergindo apenas em um ponto, a educação.

Consideravam importante a educação destas que seriam responsáveis pelo futuro homem, constituidor da nação: (....)“ser mãe era o papel mais sublime que uma mulher poderia desejar. Assim, os papéis familiares de filha, mãe e esposa eram uma espécie de preparação para a função de mãe (...) a autoridade masculina e a submissão feminina eram compreendidos no binômio ‘obediência e amor' (....) as mulheres obedeciam, porque eram delicadas e meigas" (PEDRO, 1997, p. 291).

Os cortiços já existiam desde fins do século XIX e passaram a proliferar em quase todos os centros urbanos do país. Novamente as mulheres, principalmente as mais pobres, procuravam trabalho fora de casa para compensar o pouco dinheiro que seus maridos recebiam. Este trabalho consistia em tarefas domésticas para outra dona de casa um pouco mais abastada e nestes casos, ficavam menos expostas à censura pública no que dizia respeito a sua reputação. Esta proteção não recaía para aquelas que possuíam emprego em fábricas, mas em contrapartida, as domésticas também eram taxadas de mães relapsas.

A norma oficial ditava que a mulher devia ser resguardada em casa, se ocupando dos afazeres domésticos, enquanto os homens asseguravam o sustento da família trabalhando no espaço da rua. Longe de retratar a realidade, tratava-se de 
PEGADAS HISTÓRICAS

um estereótipo calcado nos valores da elite colonial, e muitas vezes espelhado nos relatos de viajantes europeus, que servia como instrumento ideológico para marcar a distinção entre as burguesas e as pobres. ( FONSECA 1997, p. 517).

Na virada de 1800 para 1900, grandes eram as preocupações com a civilidade, com a organização da família, com leis, costumes, regras e convenções. O regime capitalista se instaurava no lugar do escravismo e a tentativa era de imprimir no Brasil o modelo burguês como modelo ideal de família, para isto dependia da mulher o comportamento familiar desejado, o que demandava um árduo trabalho por parte destas mulheres para que o núcleo familiar funcionasse a contento das expectativas de toda a sociedade: (....) "o custo de reprodução do trabalho era calculado considerando como certa a contribuição invisível, não remunerada, do trabalho doméstico das mulheres" (SOIHET 1997, p. 362).

Mais uma vez a biologia e a medicina apoiavam as intenções para uma reorganização social. Para o homem a força, a autoridade, a racionalidade; para a mulher a fragilidade, a submissão, o sentimentalismo e, claro, a vocação-mor para a maternidade.

As mães mais pobres deviam permanecer vigilantes com suas filhas, resguardando a moralidade da família, evitando o espaço da rua para si mesma e para elas. Coisa muitíssimo difícil de se fazer, pois esta mulher procurava possibilidades de sobrevivência, muitas eram, como vimos, 
mantenedoras de suas famílias e a liberdade de circulação era imprescindível para tal. Desta forma, ficava bastante complicado para esta mulher adaptar-se aos moldes de comportamento esperado, muito embora aspirassem, à semelhança das outras mulheres, ao casamento formal, aspiração esta advinda da fantasia que deste casamento derivaria a felicidade, a vida vivida corretamente, a boa reputação e consequentemente, o respeito da sociedade. Apesar deste trânsito no mundo público, dos seus trabalhos, de suas aquisições em dinheiro, que as influenciavam nas suas atitudes, na linguagem, na lida com o duro cotidiano, mesmo assim, permaneciam acreditando serem as tarefas domésticas de sua total responsabilidade.

Provavelmente devido a isto, era prática comum entre as mães pobres do início do século o acionamento de estratégias para a criação das suas crianças que, evidentemente, recebia os cuidados da mulher, porém essa mulher não precisava ser necessariamente a mãe biológica, podiam ser avós, criadeiras ou mães de criação, o que é bastante revelador quando pensamos em família. A unidade doméstica para estas famílias não se expressou, como vimos, formatada perfeitamente dentro do modelo burguês; as famílias eram menos isoladas e não se constituíam apenas de parentes consangüíneos. A precariedade da família conjugal e as óbvias necessidades econômicas entre os populares demandou uma compartilhação da criação dos filhos. Até no aspecto arquitetônico era 
denunciada esta abertura, várias casas possuindo o mesmo quintal dava às crianças a possibilidade de se infiltrarem no dia a dia de outras famílias que interagiam em sua criação. $O$ destino das crianças não era de decisão apenas do casal ou da mãe, também os avós, parentes e vizinhos compartilhavam estas decisões. Os batizados ocorriam em profusão e a mesma criança podia ser batizada diversas vezes (em casa, na Igreja, no terreiro) gerando um sistema de compadrio que também coletivizava a responsabilidade com o rebento. Se recorria também à Instituições filantrópicas ou estaduais em busca de ajuda. "A maioria das crianças em circulação vivia, entretanto, com outra família quase tão pobre quanto a de onde tinham saído" (FONSECA 1997, p.538).

Havia mães que contratavam criadeiras e as pagavam. Quando a criança completava oito ou nove anos, voltava para sua família biológica, onde ela mesma pagava o resto do seu sustento, através dos serviços que prestava na própria casa, ou através de pequenas quantias que obtinha com outros serviços feitos fora de casa.

Muitas vezes, devido ao falecimento de um filho, ou dos pais de determinada criança, ou até mesmo pela alegria que uma criança representava, havia o desejo de ter uma criança para criar. Para os pais biológicos, abrir mão da guarda dos filhos não significava desamor ou irresponsabilidade pela criança, ao contrário, esta atitude justificava-se de várias maneiras: pobreza, enfermidade da mãe, estado civil da mãe, 
falecimento de filho do casal adotivo, entre outras. Quando a mãe biológica ou o casal resolvia resgatar o pátrio poder, mesmo quando a ausência destes perdurava por anos, o fato não era visto pela sociedade como um abandono e a justiça interpretava como ação de responsabilidade deixar os filhos serem criados por outros, em melhores condições naquele momento. Entendia-se que a intenção dos pais era, afinal, deixar os filhos em boas mãos. Freqüentemente, a justiça escutava argumentos contraditórios, mas comuns dentre a população: para os pais adotivos a mãe era aquela que criava e para os pais biológicos "mãe só havia uma", ao final, a justiça quase sempre dava ganho de causa aos pais consangüíneos.

Este caráter quase imutável da identidade familiar, sem dúvida repercutia no comportamento materno e explica em parte a tendência para colocar filhos com criadeiras, avós, madrinhas e pais de criação. Sugerimos que era essencial uma mulher ter filhos para consolidar sua rede social de apoio. As crianças que, quando pequenas, dependiam dessas redes para sobreviver, eram as mesmas pessoas que, alguns anos mais tarde, assumiriam a responsabilidade pelo sustento dos mais velhos ou mais fracos da rede (FONSECA 1997, p.540).

No entanto, isto não significa dizer que a relação se desse apoiada simplesmente na exploração do trabalho infantil: "Num contexto onde não 
PEGADAS HISTÓRICAS

existia pensão de velhice, invalidez ou aposentadoria (....) Havia uma complementaridade sistêmica entre as diferentes etapas de vida" (FONSECA 1997, p.540). Não era contradição ou mesmo hipocrisia, apelar para a noção de "amor materno" por parte das mães biológicas ou a ênfase na boa educação moral, argumento utilizado pelo pai consanguíneo, quando estes intencionavam reaver a guarda dos filhos: "Sua responsabilidade era zelar pelo bem do seu filho, não necessariamente de conviver com ele. A identidade familiar, centrada nos laços de sangue, era garantia suficiente para saber que, a longo prazo, o vínculo não seria rompido". (FONSECA 1997, p.541).

Ainda neste período, ou seja, quase na entrada deste século, grande parte do proletariado, principalmente nas fábricas de fiação e tecelagem que ainda não mecanizadas, era composto de mulheres e crianças.

A crescente incorporação da mulher no mercado de trabalho e na esfera pública em geral suscitou ampla discussão na sociedade. Muitos, ao lado de teóricos, médicos, economistas etc, consideravam isto extremamente nocivo para a família, pois: (....) "as crianças cresceriam mais soltas, sem a constante vigilância das mães" (RAGO, 1997, p.585).

A industrialização vai absorvendo e desvalorizando muitas tarefas que, anteriormente, exercidas pelas mulheres no interior de suas casas (tecidos, pão, doces, fósforos etc) e fortalecendo a idéia da maternidade como a grande missão feminina. Sabemos, intentava-se a divisão entre o 
público e o privado, e então, a Igreja, os industriais, os positivistas, os liberais, os socialistas e os anarquistas exaltam a mãe como aquela que preparará o futuro cidadão, contribuindo para o engrandecimento da nação. É importante dizer também que havia médicos, como também pessoas do movimento operário e, evidentemente, muitas mulheres, que protestavam contra a exploração do trabalho feminino e infantil, e defendiam o direito ao trabalho digno, à educação, o acesso a todos os campos da cultura e o direito ao voto para as mulheres.

A década de sessenta chega ainda com a crença que a mulher era feita essencialmente para a maternidade e o casamento: "Só muito recentemente a figura da 'mulher pública' foi dissociada da imagem de prostituta e pensada sob os mesmos parâmetros pelos quais se pensa 0 ‘homem público" (RAGO 1997, p. 604).

A modernização da sociedade brasileira faz eclodir muitos conflitos que advêm, principalmente, das relações de trabalho. Os diversos grupos sociais se organizavam para exercerem suas reivindicações e as mulheres também se fazem porta-vozes de seus direitos.

As primeiras pautas reivindicatórias, que datam o início do século, se limitam exclusivamente ao trabalho dos homens, sem a menor referência ao trabalho fora das fábricas e muito menos às especificidades do trabalho das mulheres, estas nem são reconhecidas como parte da população economicamente ativa. 
Desde a década de 30, o Estado passou a interferir nas relações de trabalho e a legislação trabalhista é promulgada como corpo jurídico válido nacionalmente.

"Até o golpe militar de 1964, a noção de cidadania permanece vinculada ao emprego estável, assalariado e urbano (....) " (GIULIANI 1997, p. 641)

Ocorre que, até esse momento, a maioria da população brasileira mora no campo, seu meio de vida é a produção familiar ou a produção informal e instável, e, para estes, não há o reconhecimento social.

Nos anos 60 , as questões salariais são o alvo principal das reivindicações e as questões relativas às condições de vida são primordialmente mediadas por estas. Os programas sociais ou de assistência mantém a mesma filosofia de governos anteriores, ou seja, o público-alvo é a família institucionalmente constituída em torno do chefe de família, representante único das necessidades e exigências de todos os familiares.

Dez anos antes, a classe média no Brasil vive um período de ascensão, há um evidente crescimento urbano e industrial. A mulher no mercado de trabalho era fato cada vez mais comum, embora o homem fosse visto como chefe da casa e o trabalho feminino subsidiário ao trabalho deste. As campanhas estrangeiras, com o fim da segunda guerra, pregavam a volta da mulher ao lar, e às mulheres eram renovadas idéias antigas que falavam 
da importância da dona de casa, mãe e esposa no panorama de suas vidas. As revistas femininas surgiam corroborando o modelo burguês de família, sendo o pivô a mulher e sua essência feminina. O patrulhamento moral da sociedade em geral, subdividia as jovens em moças de família e moças levianas, sendo que as boas moças sempre seriam as que se preparavam e se resguardavam para o casamento. Guardadas as diferenças, isto não está muito longíquo do que vivemos hoje em dia, perto do terceiro milênio.

Serviços de consumo coletivo dava a oportunidade de emprego na enfermagem, magistério, medicina, funcionalismo público, assistência social, etc, concomitantemente, apareciam oportunidades de formação profissional e mudança de status social da mulher. Ainda assim, existia conflito entre a idéia de matrimônio e vida profissional, pois: "A mulher casada deveria ter o marido e os filhos como centro de suas preocupações". (BASSANEZI 1997, p. 627).

Não obstante o surgimento de práticas de controle de natalidade, nenhuma revista feminina da época mencionava o assunto. Era claro que os casais deveriam ter filhos, no plural, e, as publicações femininas pregavam que ser mãe, mais que um direito, uma alegria, era um dever social. Isto era eminentemente para a mulher formalmente casada, já que mães unidas, solteiras ou com filhos ilegítimos, eram fortemente estigmatizadas. 
"A modernização da sociedade brasileira tem atingido de maneira diferente os diversos grupos sociais e produzido várias formas e níveis de conflito" (GIULANI 1997, p. 640).

A maior parte das reivindicações e dos conflitos eram derivações do mundo do trabalho, no entanto apareciam também conflitos provindos de outras áreas do convívio social, como a vida familiar. Metade da população brasileira, como dissemos, era rural, com vínculo empregatício instável ou produção familiar. O Estado começa a assimilar as associações profissionais como interlocutoras, reconhecendo como oficiais os sindicatos, mas permanece definindo os direitos e deveres das práticas produtivas. A questão salarial é, até a década de 60 , principal eixo de discussão entre sindicatos e Estado. Contudo, isto vai se modificando, principalmente nos centros urbanos. Discussões sobre condições de vida são inseridas e criados outros fóruns de debates, como associações e movimentos populares. Na década de 80 também os bóia-frias se organizam e mobilizam a sociedade para suas necessidades. A população trabalhadora, de ambos os sexos, fala de suas respectivas responsabilidades no seio familiar. Para as mulheres rurais a fronteira entre os limites do lar e do trabalho é tênue, e é o pai ou o marido a autoridade familiar. Nos grupos comunitários formados pela Igreja, há a preocupação com a injustiça social e é ressaltado o papel da mulher como mãe, esposa e dona de casa, resgatando-se a identidade feminina intimamente ligada aos laços afetivos e ao lar. Começa a surgir um 
PEGADAS HISTÓRICAS

movimento que se preocupa com as condições de vida da mulher, seu duplo esforço, na administração simultânea de assuntos relacionados tanto à esfera pública quanto à esfera privada.

"Os clubes de Mães e os grupos de Mulheres Trabalhadoras nascem como uma espécie de instrumento de denúncia da ausência ou da precariedade dos serviços coletivos municipais (....) ensino e saúde estão no centro dos debates (....) uma articulação de dimensões da vida social e individual antes impensável: mulheres-saúde-cidadania" (GIULANI, 1997 p.647).

É em 1970 que mulheres de segmentos urbanos participam do Movimento de Luta por creches. Desde 60 são avaliados e revisados os papéis sociais das mulheres como mães, esposas e donas de casa deixando, por vezes, a discussão sobre as dificuldades no mercado de trabalho, de lado. Estes grupos de mulheres, através de suas reivindicações, fizeram possíveis as promulgações de leis mais coerentes com a efetiva atuação econômica e familiar das mulheres, demandando serviços públicos de apoio à mãe trabalhadora. Surgem, cada vez mais, questionamentos quanto às atribuições domésticas e extra-domésticas típicas de homens e de mulheres: "Tais questionamentos mostram que para renovar o conceito de feminilidade, é indispensável renovar também outro conceito, o de masculinidade" (GIULANII 1997 p. 651). 


\section{PEGADAS HISTÓRICAS}

Finalmente, é preciso reforçar que as diferenças entre as mulheres de todo o país são muitas, portanto, são diferentes suas trajetórias. Falamos principalmente, mas não apenas, das mulheres trabalhadoras por serem estas que impulsionam através de seu modo de vida e do seu cotidiano uma contribuição para a consolidação das relações democráticas. Contudo, cada vez mais as mulheres ocupam o espaço público e isto certamente afeta e revisiona a imagem social da feminilidade. 


\section{CONVERSANDO COM ALGUNS AUTORES}

A partir de extenso e minucioso estudo, ARIÈS (1978), nos desfia paulatinamente a evolução, através dos séculos, de temas relacionados a infância. Localiza a descoberta desta infância no século XIII e, vai acompanhando-a na história da arte e na iconografia, através dos séculos $\mathrm{XV}$ e XVI, mostrando o crescimento da atenção voltada para este assunto. Os sinais desta maior atenção que observou, tornam-se particularmente numerosos e significativos no fim do século XVI e no decorrer do século XVII.

Para ARIÈS (1978), o sentido de infância não significa necessariamente o mesmo que afeição pelas crianças, trata-se mais da consciência de uma particularidade infantil, distinguindo-a da vida adulta ou mesmo do jovem.

Contudo, é por volta de 1760-70 que consolida-se verdadeiramente a celebração da criança e, simultaneamente, um aumento progressivo de publicações que estimulam os pais, principalmente a mãe, a novos sentimentos ante seus filhos. ROUSSEAU, citado por ARIÈS (1978), em sua obra Émile, escrita em 1762, cristaliza tais idéias, esboçando a família moderna apoiada no amor materno, um de seus principais pilares. 
Segundo BADINTER (1985), a associação extremamente comum da palavra amor e a palavra materno intenta promover a mulher-mãe e o amor em uma junção constante e perene. Esta promoção traz embutida um valor ao mesmo tempo natural e social, que a autora considera que é facilmente adotado devido ao subtexto de se constituir algo favorável à espécie e à sociedade. Ou seja, de maneira geral todos acham que o amor materno é inato à natureza feminina: primeiro a mulher há que ser mãe, e depois há que amar infinitamente a seu filho, e isto é um dos propulsores da natureza para a preservação da espécie e do bom encaminhamento da sociedade.

Ademais, maternidade e gravidez são termos usados nos mais diversos e distintos loci do convívio humano.

Muitas vezes, também se nos apresenta o entendimento indissociado destas duas idéias: a grávida é (ou será) mãe e a mãe é (ou foi) grávida.

Certamente, é inegável a relação que há entre a qualidade ou condição de mãe e o estado da mulher durante a gestação.

As duas condições sofrem influências sociais e psicológicas, mas apenas o processo gravídico possui uma parte, especificamente seus aspectos biológicos, que são passíveis de descrição mais objetiva. Contudo, se considerarmos a gravidez apenas como parte possível (ou passível) do processo de maternidade e vice-versa, uma necessariamente não dependerá da outra para se desenvolver. 
SANTOS (1998), coloca sob foco o tema da adoção e traz para isto a discussão apresentada inicialmente por CHODOROW (1990), sobre as diferenças entre maternidade e maternagem, afirmando que vivenciar a primeira não implica o desejo de exercer a segunda: “(....) pois 0 desejo/necessidade de gerar um filho pode ser resultante - ainda que não conscientemente - da pressão social que impõe às mulheres a assunção do papel de mãe, conforme modelo ideal traçado desde Rousseau e que subentende a identificação absoluta entre o ser mulher e o ser mãe. Nesse sentido, um só pode se realizar no outro" (SANTOS 1998, p.103).

É de se considerar também a existência de obstáculos sociais, de dificuldades cotidianas e até mesmo de questões menos concretas e mais subjetivas que impedem ou dificultam a realização do exercício da maternagem, como condições sócio-econômicas e circunstâncias psicológicas.

BADINTER (1985), afirma que muitos acreditam existir algo próximo a um dispositivo interno na mulher, que acionado pela gravidez, se exerceria na emergência de todas as respostas quanto a condição de mãe. O sentido naturalista e fisiológico que corresponde a gravidez, um fenômeno momentâneo, é estendido para a maternidade, que é uma ação a longo prazo.

A associação direta entre parir, amamentar e cuidar posteriormente da criança e, possivelmente, a associação também entre mulheres e fêmeas 
em geral, têm apontado por muito tempo para estudos de áreas diversas, a conclusão de que é da mulher a responsabilidade do prolongado cuidado da infância.

Ainda segundo BADINTER (1985), afirma também que muitos defendem a idéia de instinto materno baseados em uma filosofia dualística; crêem que sendo a aparência diferente da essência, não é importante as condutas (aparência) distintas entre as mães se, no fundo (essência) todas possuem genuíno amor materno. Coloca-nos que a palavra instinto, conceito bastante discutido e problematizado, foi perdendo sua força e sendo substituído pela palavra amor, e que havia nisso a intenção de ressaltar a diferença entre homens e animais, mas que a idéia do amor materno ainda está fortemente associado, conceitualmente, à antiga idéia de instinto materno. "Mesmo reconhecendo que as atitudes maternas não pertencem ao domínio do instinto, continua-se a pensar que o amor da mãe pelo filho é tão forte e quase geral que provavelmente deve alguma coisinha à natureza. Mudou-se o vocabulário mas conservaram-se as ilusões". ( BADINTER 1985, p.21)

A autora, em contrapartida, defende que o amor é apoiado no desejo e que, assim como todos os sentimentos humanos, é incerto, imperfeito, e que, ao contrário de ser inato, é adquirido, e que este desejo sofre grande influência social: "Os valores de uma sociedade são por vezes tão 
imperiosos que tem um peso incalculável sobre os nossos desejos" (BADINTER 1985, p.16).

Sobre esta influência, contribui DEL PRIORE (1993), colocando-nos a par da força do Estado e da Igreja no Brasil pré- colonial. Demonstra que a partir de um discurso normalizador, promovia-se uma imposição social no comportamento feminino que: (....) "consistia na domesticação da mulher, no sentido de torná- la responsável pela casa, família, casamento e procriação (....)" (DEL PRIORE 1993, p.26).

Segundo a autora, o Estado incentivava o casamento com vistas no processo civilizatório. A Igreja, por sua vez, regida por seus dogmas, restringia a mulher aos cuidados da casa e família e possuía como aliada de suas posições, o discurso médico, que assegurava a procriação como caminho natural para toda mulher normal.

Cerceava-se intensamente as práticas femininas utilizando-se como um eixo central a maternidade, que funcionaria como controlador social: "Fora do manso território da maternidade, alastrava-se a melancolia, vicejava a luxúria e por tudo isto a mulher estava condenada a exclusão" (DEL PRIORE 1993, p.27).

O uso dos corpos no casamento tinha na procriação a redenção dos pecados e o caminho ressurreicional. $O$ desregramento libidinal era considerado um rebaixamento dos homens à condição animal, urgia impedir que a mulher se tornasse para o homem a oportunidade de queda e 
perversão. Para isto, fazia-se necessário ao casar, a imediata concepção, pois: "Apenas como mãe, a mulher revelaria um corpo e uma alma saudáveis, sendo sua missão atender ao projeto fisiológico-moral dos médicos e à perspectiva sacramental da Igreja" (DEL PRIORE 1993, p.31).

Em tempos longínquos, o mito das deusas, que se alimentava do profundo mistério que representava a concepção, é destituído quando se descobre a fundamental participação masculina neste processo. Relata DEL PRIORE (1993), que na Europa, com as descobertas de Leeuwenhoek (1623-1723) e De Graaf (1641-1673), demonstrava-se que a mulher não era apenas a guardiã do feto, mas que contribuía ativamente na concepção. Mesmo assim, muito devido à repressão da Inquisição, Portugal resistia a estas novidades, mantendo arcaica a sua visão médica.

Com o concílio tridentino, a Igreja estabelece novas diretrizes que objetivava alcançar mais de perto as populações. No Brasil, as devoções pessoais e o surto mariológico, ou a devoção à Nossa Senhora, foram elementos de grande auxílio nesta aproximação. Este modelo feminino, apoiado na devoção à Santa, fez-se bastante útil aos interesses da Igreja e do Estado, deixando para a mulher o espaço doméstico, o papel de virgem ou de "santa mãezinha", fornecedora do trabalho de base com relação à criação dos filhos e o trabalho doméstico, para o encaminhamento do projeto colonizador. (....) "Mas pensar a história das mães significa, sobretudo, perceber que o fenômeno biológico da maternidade, sua função social e 
psicoafetiva, vai transformar-se, ao longo deste período, num projeto de Estado moderno e principalmente da Igreja para disciplinar as mulheres da colônia, fazendo-as partícipes da cristianização das Índias" (DEL PRIORE 1993, p.45).

À revelia da Igreja, contudo, grande parte das mulheres viviam em uniões consensuais, a instituição religiosa, por sua vez, possuía um certo grau de tolerância quanto a isto, e trabalhava para que, ao menos, houvesse uma projeção futura de um casamento sacramentado. Muitas vezes, os casais formalizavam suas uniões após o nascimento dos filhos. A Igreja persuadia mostrando vantagens no casamento como a sua indissolubilidade, que daria à mulher mais segurança e proteção, afora a dignidade preservada. Afinal, os abandonos, bastante comuns, representavam para a mulher com filhos, esforços extras para sustentá-los. Muito embora existisse esta grande gama de formas de convivência sexual, estas freqüentemente se assemelhavam aos casamentos formais de mulheres pertencentes a elite. Esta semelhança se devia à mobilidade espacial dos maridos e companheiros que se inseriam no projeto de organização e instalação do sistema colonial. Com a ausência do marido ou companheiro, às vezes provisória quando buscava-se riquezas, às vezes permanente, quando do abandono, cabia às mulheres a chefia da família, o que reforçava uma matrifocalidade e o poder informal da maternidade. 
A maternidade se traduzia em inúmeras formas que não somente a biológica. Avós criavam netos como filhos, mulheres adotavam crianças, esposas ou concubinas criavam filhos de seus maridos com outras mulheres e, muitas vezes, criavam-se filhos ilegítimos junto aos legítimos. Tanto homens como mulheres admitiam, no interior de suas famílias, filhos bastardos.

Ao mesmo tempo que isto ocorria devido a uma maior sensibilidade dirigida à criança e à infância, havia também como influência, o imperativo papel feminino, que era o de zelar, cuidar e educar a prole diversa, independente de sua origem.

Assim, era na maternidade onde se encontrava com muita freqüência, quando não apenas nela, a solidariedade feminina. Quando urgia a necessidade preemente de auxílio mútuo, para a sustentação da vida e dos filhos.

Neste cenário, Igreja e Estado lutam para combater as ligações ilícitas, fazia-se importante não confundir filhos legítimos com bastardia e, principalmente a igreja, começa a desenhar o padrão de comportamento da boa mãe. A fabricação da santa mãe se dá com a percepção da forte influência da mulher-mãe na família e, conseqüentemente, na sociedade. A boa mãe servia como exemplo e também como instrumento para o adestramento das mulheres, como estímulo para a tarefa de passar para a sua descendência normas e valores de interesse destas instituições. Este 
estereótipo paulatinamente construído, de mãe ideal, intentava também fortalecer a quase sempre malfadada empresa de normalizar as uniões, além de mascarar a realidade de desigualdades sociais, raciais e econômicas.

Os critérios de reprodução, hábitos contraceptivos, esterilizantes ou procriativos eram exercitados não obstante as imposições da Igreja: "Uma grande família seria sempre sinônimo de solidariedade e perpetuação". (DEL PRIORE 1993, p.155).

Os filhos sobreviventes, pois a mortalidade infantil dizimava muitos, seriam futuramente responsáveis pelo sustento de suas mães solitárias ou abandonadas. A procriação era reflexo da mentalidade binária, assim como a mentalidade católica cristã e a lógica equilibravam-se em opostos, a mulher devassa não concebia e a mulher ideal tornava-se mãe.

A mesma autora coloca-nos, também, como contraponto, que é esta mesma maternidade o recurso que as mulheres desta época lançavam mão para se furtarem deste enorme controle: "Servia para se defenderem da exploração doméstica e sexual, do abandono e da solidão nas duras condições materiais de vida dos tempos coloniais" (DEL PRIORE 1993 p.156).

Atualmente, estas ideologias parecem estar presente nas várias instituições de nossa sociedade e, muito provavelmente, ecoam também em lugares mais privados. 
KITZINGER (1978), faz uma crítica a uma fatia da produção literária especializada que fornece métodos e fórmulas de criar filhos. Como ter um bebê, como criar e educar os filhos, como ser uma boa mãe, principalmente a mãe de primeiro filho, são os assuntos diletos destes trabalhos e também das pessoas em geral, próximas a esta mãe. Considera que grande parte desta artilharia, movida muitas vezes por modismos, é voltada para a maternidade devido ao ensejo de se produzir uma sociedade superior em qualidade, o que reforça o ponto de vista que tem a mãe como principal retransmissora dos valores fundamentais da sociedade.

A autora inclui a paternidade também como alvo, mas é à mãe (principal responsável pela saúde dos filhos e saúde em sentido amplo), que se direcionam a maioria destas informações que, vindas de toda parte, acabam por se constituírem foco de tensões e culpas para esta mãe. "Há tão pouca compreensão social do que realmente implica a tarefa fatigante de ser mãe, que em geral as mulheres são levadas a explicar a sua experiência pós parto inteiramente em termos de estados internos, hormônios, de psiquismo e de desadaptação às novas tarefas ocupacionais e emocionais da maternidade..." (KITZINGER 1978, p. 40).

Cotejando com DEL PRIORE (1993): "A maternidade portanto, extrapola dados simplesmente biológicos; ela possui um intenso conteúdo sociológico, antropológico e uma visível presença na mentalidade histórica" (DEL PRIORE, 1993, p.18). E também, acrescentaria, conteúdos psíquicos 
que com certeza, são profundamente comungados às dimensões mencionadas, contribuindo para a reflexão e a compreensão sobre os significados da maternidade.

Nas sociedades contemporâneas, a importância que é atribuída à gravidez na adolescência diversifica-se desde considerações a propósito da dinâmica populacional até questões decorrentes das diferentes pautas culturais (REIS, 1993).

Com as transformações ocorridas nas últimas décadas, era esperado uma redução da maternidade e gravidez entre as mulheres jovens, dado que estas, mais inseridas no mercado de trabalho, não teriam como opção única e essencial, o papel de mãe e dona de casa. Contudo, os registros apontam para um aumento da taxa de fecundidade entre as adolescentes, muito embora as taxas referentes à fecundidade da mulher de um modo geral, venham diminuindo nos últimos anos. (DE PAULA, 1992).

Esta maneira de ver a mulher, depositando a maior importância em sua função reprodutiva, tem suas reverberações em nossa cultura, nas relações sociais, de trabalho, nas relações entre homem e mulher e na família.

Por outro lado, afirma MACIEL (1994), gerar, parir e criar têm seu valor também bastante banalizado e o poder permanece pertencendo aos detentores da semente necessária à concepção, os homens. 
O que se passou (....) foi que estas características femininas desceram na escala de valores junto com os seus sujeitos (....) e as condições de gestação, parto e puerpério foram instaladas na nova lista de prioridades sociais, no item que dizia respeito a manutenção da espécie, que mais tarde quando da revolução industrial, explodiu na manutenção da força de trabalho (MACIEL 1994, p. 23).

A supervalorização de realizações no âmbito intelectual e econômico é diametralmente proporcional à desvalorização das funções maternas e domésticas. O mito outrora colado à imagem da mulher dá lugar ao mito vinculado ao homem, ao masculino. Concomitantemente, a veiculação da idéia, que o valor está no que se tem, no que se possui, cria estereótipos, distorce a figura humana esvaziando-a justamente de humanidade. 


\section{IDENTIDADE E PSICOLOGIA}

No âmbito da psicologia, a compreensão e conceitualização de identidade se dá a partir do enfoque nos processos de identificação e as contribuições destes para o desenvolvimento da personalidade, sendo portanto a identidade posterior a estes processos.

O interesse nos processos de identificação é assumido então como algo poderoso na formação de caráter. No século passado, teóricos da psicologia propõem os conceitos de imitação e de sugestão para compreender o comportamento social. Surge a idéia de que os papéis sociais apreendidos pelos indivíduos, através da representação de papéis, são copiados de modelos. Na virada do século, desenvolvimento de estudos na área de psicologia infantil, denotavam a presença da cópia de modelos no processo de desenvolvimento da criança.

Hoje, o conceito de identidade aborda "a influência dos modelos parentais, a importância do social nas origens do auto conhecimento, a tentativa de explicação desses processos através de imitação, mostrando ainda a confusão de conceitos, sobretudo entre imitação e identificação" (MACEDO 1983, p. 27).

Para MACEDO (1983), o conceito de identificação tem valor fundamental na obra de Freud, mais do que um mecanismo psicológico, a identificação é considerada a operação pela qual o indivíduo se constitui. De 
início, Freud relacionou identificação aos sintomas histéricos, observando a partir daí, a existência de um elemento comum e inconsciente pertencente às pessoas em geral. Freud mostra o papel da identificação na melancolia, no processo narcísico, sua grande influência no processo edípico e, mais tarde, a importância crescente da noção de identificação nas reformulações introduzidas em sua obra.

Em 1936, ANA FREUD, em seu estudos, percebe processos de identificação nos mecanismos de defesa do indivíduo, associando-os a mecanismos de projeção e introjeção.

Em 1950, ERIKSON introduz na psicanálise o estudo sistemático da identidade. A identificação, é em seu trabalho, relacionada ao processo de desenvolvimento da criança e a identidade é referida como resultado das múltiplas identificações que o indivíduo experimenta no decorrer de sua vida, principalmente na adolescência. Não considera, no entanto, identidade apenas como a mera somatória de identificações infantis ou o conjunto adicional de identificações que se processam posteriormente. Apenas isto, afirma, "não resulta em uma personalidade operante" , e prossegue:

(....) no final da infância, o indivíduo defronta-se com uma hierarquia compreensível de papéis, desde os irmãos mais novos aos avós e quem mais pertencer ao círculo familiar mais vasto $(. .$.$) isto proporciona um conjunto de expectativas sobre o$ que ele será quando mais velho, e as crianças muito pequenas 
identificam-se com muitas pessoas, num certo número de aspectos, e estabelecem uma espécie de hierarquia de expectativas que, depois, procura 'verificação' mais tarde na vida (ERIKSON 1976, p.159).

Portanto, o autor sugere uma interação, cada vez mais madura, entre introjeção, identificação e formação de identidade. Além de apontar a importância da hierarquia de expectativas e da posterior verificação destas, aponta a suma relevância da cultura para a formação de identidade. O indivíduo possui a necessidade da contrapartida cultural, assim como é preciso que a sociedade, em sua cultura, forneça oportunidades para desenvolvimento de um senso de identidade. Desta forma, mudanças históricas e culturais podem interferir na estruturação daquelas expectativas infantis.

A cultura e a formação de identidade é portanto, via de duplo vetor, o sujeito reconhece a comunidade em que está inserido e a comunidade, sentindo-se reconhecida pelo sujeito, também o reconhece. É sempre um processo que ocorre simultaneamente no âmbito do indivíduo e de sua cultura.

A noção de singularidade e unidade frente às mudanças que ocorrem na vida do indivíduo é fundamental ao conceito de identidade. Segundo ERIKSON (1976): (....) "a identidade seria um sentido consciente da singularidade individual junto a um esforço inconsciente para manter a 
singularidade da experiência e uma solidariedade para com os dois ideais de um grupo" (ERIKSON 1976, p. 21) .

A formação de identidade portanto, não se dá de forma linear, seu desenvolvimento implica a existência sucessiva de crises. Para ERIKSON (1976), as crises são imprescindíveis e constituem-se na necessidade de opção por uma ou outra direção; mobiliza recursos de crescimento, recuperação e novamente, diferenciação. Entendida sob uma perspectiva psicossocial, o processo de identidade tem início nos primórdios do relacionamento mãe- bebê, na crescente diferenciação, na consciência de si e de outros, desde a pessoa materna até a humanidade. A variação de modelos socialmente significativos e suas possíveis combinações são impostos ou limitados pelo momento histórico: "tais modelos serão úteis na medida em que preencherem as necessidades das fases de amadurecimento do organismo, ao estilo de síntese do ego, e às exigências da cultura" (MACEDO 1983, p. 33).

Ainda para ERIKSON (1976), a identidade tem crise normativa na adolescência, momento que permite ao indivíduo encontrar uma forma (em termos de identidade ) que determinará sua vida ulterior.

Desta forma, as fases decisivas para esta formação são, segundo ele, as seguintes: 
1. O bebê e a mutualidade do reconhecimento: esta fase funda, na relação mãe/bebê, o desenvolvimento de uma confiança básica e uma atitude genérica ante o próprio eu e o mundo.

2. O começo da infância e a vontade de afirmação do eu: nesta etapa, há um aumento de aptidões bem como de inaptidões conferindo à criança inúmeras oportunidades de testar sua vontade e batalhar sua autonomia.

3. Infância e a previsão de papéis: com o desenvolvimento da locomoção, da linguagem e da capacidade de representação, ampliando seu relacionamento com o mundo.

4. Idade escolar e identificação da tarefa: tem-se o aprendizado ágil e rápido, capacidade de compartilhação das tarefas, sentimento de competência, não só a capacidade de aprender, mas de ensinar e trabalhar.

5. Adolescência: para o autor esta fase é a mais importante para a formação de identidade, quando ocorre a necessidade de se buscar um novo sentido identitário continente a todas as transformações fisiológicas, psicológicas e sociais que o jovem passa. Inicia-se outro estabelecimento de identificações com papéis e ideais, que constituirão o cerne de uma identidade básica. Isso em meio à difícil tarefa de incorporar os papéis e aptidões cultivados anteriormente, na infância, com as exigências mais atuais e amplas do dia-a-dia e da sociedade em geral. Na nossa sociedade é estendido cada vez mais o período entre o início da vida escolar e o acesso final do jovem ao trabalho especializado, ERIKSON (1976), considera 
necessária uma moratória social e mental, deixando para o jovem tempo e espaço para tornar-se adulto produtivo e integrado. $\mathrm{O}$ autor afirma que a ideologia é a instituição social guardiã da identidade, na medida em que é através dela que os sistemas sociais penetram nas gerações subsequentes.

6. Para além da identidade: ERIKSON (1976) se refere aqui tanto àquilo que existe no ser humano além da identidade psico-social, que é o seu "eu", centro da consciência e da vontade que pode transcender esta última, como às fases do ciclo vital, além da adolescência.

$\mathrm{Na}$ maioria dos estudos sobre a família, as teorias encaram a maternidade como um dos seus eixos centrais, mas apesar da importância que Ihe é conferida como produtora e reprodutora social, não há uma explicação sobre como e porque esta se dá. CHODOROW (1990), afirma que esta omissão se apóia em vários pressupostos, sendo o mais comum o ponto de vista biológico e o ponto de vista bioevolucionista. O interessante da colocação de CHODOROW (1990), é justamente mostrar que tais pressupostos não servem para elucidar a questão e sim para colocar um ponto final nela, ou seja, para a biologia a estrutura do oferecimento dos cuidados maternos e paternos é explicativa por si mesma, e, assim como do ponto de vista bioevolucionista, as mulheres são a principal parte na atividade de procriar e cuidar da prole hoje, porque sempre o foram e, assim foi funcionando. 
CHODOROW (1990), procurou investigar, com base na psicanálise, sobre como as mulheres são produzidas também por si mesmas, como produzem determinada posição de pertencimento; se há uma explicação biológica no fato de cuidarem de crianças ou se são elas que devem, por algum desígnio, desempenhar toda e qualquer exigência do cuidado infantil.

A autora percebe que a reprodução da maternação, com tudo que isto implica, tem início na primeira relação mãe/bebê e destaca três aspectos fundamentais para isto ocorrer: primeiro a situação psicológica básica para o cuidado infantil; segundo, a saída desta situação com a lembrança de uma intimidade peculiar que se quer recriar e, por fim, a base para as futuras expectativas de mulheres como mães. Voltaremos a estes aspectos mais adiante.

A teoria psicanalítica, é sabido, delega grande importância à relação inicial mãe/bebê na constituição do sujeito. A participação da mãe neste binário, por sua vez, está alicerçada em seu relacionamento mesmo, inicial, com a própria mãe.

Este relacionamento inicial, gera, cria, para todas as pessoas, a capacidade de cuidar, além de um desejo de recriar este relacionamento mesmo.

Para CHODOROW (1990), na sociedade industrial ocidental, este relacionamento mãe- filho revela as atitudes e expectativas, conscientes ou não, que as pessoas possuem em relação às suas mães, em particular, e às 
mulheres, em geral. Ou seja, tais expectativas integram a questão da reprodução da maternação.

Estudando exemplos clínicos e culturais, a autora conclui haver uma distinção entre as experiências pré-edípicas de meninos e de meninas e que tais diferenças são produto da organização assimétrica do cuidado com os filhos, infra -estrutura de nossa cultura familiar.

Voltando aos aspectos fundamentais da reprodução da maternação, utilizando-se de conceitos e ferramentas da teoria psicanalítica, CHODOROW (1990), observa que as mães tendem a não perceber os filhos bebês como separados delas e, no caso das mães de bebês meninas, esse senso é mais forte e dura mais tempo. Suas apropriações e divergências quanto a inúmeros conceitos tais como narcisismo, simbiose, castração, bem como a constructos teóricos, como o complexo edípico, têm como finalidade desfiar, sob o ponto de vista psicanalítico, como chegou-se a tal conclusão e quais implicações quanto aos processos de desenvolvimento do sujeito.

"A identificação primária e a simbiose com filhos tendem a ser mais fortes e as catéxis de filhas tem mais probabilidade de reter e acentuar elementos narcísicos, isto é, basearam-se na vivência de uma filha como uma extensão ou sósia da própria mãe, com catéxis da filha como um outro sexual , em geral permanecendo um tema mais fraco e menos significativo" (CHODOROW 1990, p.141). 
Continua a autora, citando o livro de Signe Hammer, de nome Filhas e Mães: Mães e Filhas que trata de entrevistas com mais de setenta e cinco mães, filhas e avós que relatam questões de identificação primária, unicidade e separação, que perseguem os pares mãe/filha desde a mais remota infância da filha até quando ela vem a ser mãe, ou mesmo avó.

Portanto, meninas e meninos desenvolvem diferentes capacidades relacionais e diferentes sensos do eu, como resultado do fato de crescerem numa família na qual a mulher materna.

Isto que é maternação para CHODOROW (1990), perpetua-se através de mecanismos psicológicos e sociais estruturalmente induzidos. Ou seja, não é produto imediato da fisiologia. A autora considera que estes mecanismos geram tensões, dependendo do desenvolvimento interno do sistema sexo/gênero e das condições históricas e sócio-culturais externas. Finalmente, aponta que a organização social do cuidado com os filhos produz desigualdade entre os sexos, e não apenas diferenciação de papéis. 


\section{PRESSUPOSTOS TEÓRICOS}

Este estudo analisa, através de método qualitativo, os discursos produzidos por mães jovens, atendo-se aos relatos que aí ocorrem sobre a maternidade. Para a interpretação dos dados foram utilizados pressupostos concernentes à perspectiva do sistema indiciário, da "grounded theory" e do conceito das representações sociais.

Falaremos a seguir de cada uma.

SISTEMA INDICIÁRIO

Este conceito é descrito ou recriado por CARLO GINZBURG (1989), que por meio de seus ensaios, promove uma profunda reflexão sobre as raízes de um paradigma epistemológico assentado na observação do detalhe.

Em seu livro "Mitos, emblemas, sinais", mais especificamente no capitulo que trata dos sinais, que aqui adotaremos para a compreensão deste conceito, GINZBURG (1989), faz uma análise minuciosa deste paradigma, apontando como este ainda não fora teorizado explicitamente.

Faz uma análise comparativa entre o método "morelliano", a técnica interpretativa de Freud e as técnicas utilizadas pelo escritor Arthur Conan Doyle, por meio de seu conhecido personagem literário, Sherlock Holmes.

GINZBURG (1989), vai mostrando como, desde o século XIX, emergiu um modelo epistemológico que persevera no âmbito das ciências 
humanas e que permanece operante desde então até nossos dias. Relata que escritos de um homem de nome Ivan Lermolieff, eram na verdade de autoria de Dr. Morelli, médico e crítico de arte. Entre 1874/76, Dr. Morelli usou seu pseudônimo para assinar ensaios e alguns anos mais tarde, o autor assume seu verdadeiro nome e seu método passa a ser conhecido por método morelliano, que consistia em diferenciar obras de arte falsas das reais através de características imperceptíveis para a maioria das pessoas. Este médico que usava pseudônimo alemão, dizia que era preciso examinar pormenores negligenciáveis pela maioria das pessoas, considerava os pormenores menos sofríveis da influência das características da escola que o pintor pertencia, sendo portanto, mais reveladores da personalidade do autor. Chamava a atenção em seus ensaios, à lóbulos, unhas, formas de dedos etc, para a identificação da autoria da obra. Segundo GINZBURG (1989), outro autor de nome Castelnuovo havia comparado este método ao método utilizado por Doyle, em sua literatura policial, que de forma muito semelhante, atento a pormenores, construía uma malha de pistas que levavam o leitor a ir esboçando, paulatinamente, o mosaico da trama até o desenlace final.

O autor nos mostra que no ensaio sobre o Moisés de Michelângelo, escrito por Freud, há uma passagem onde este menciona a influência que o Dr. Morelli exerceu sobre sua pessoa muito antes da descoberta da psicanálise. Posteriormente Freud, em seu método de interpretação, mostra 
a extrema relevância dos resíduos, daqueles dados que ao contrário de saltarem à vista, são marginais.

As pistas, sintomas para Freud, indícios para Doyle e signos pictóricos no caso de Morelli, possuem similares em épocas muito antigas como em textos de jurisprudência mesopotâmicos. Mas essa atitude, orientada para a análise através da reconstrução de indícios, remonta épocas anteriores à documentação escrita.

O fator comum entre as técnicas utilizadas pelos autores citados, se fundamenta, como nos demonstra GINZSBURG (1989), em um paradigma indiciário: "No final no século XIX - mais precisamente, na década de 187080 começou a se afirmar nas ciências humanas um paradigma indiciário baseado justamente na semiótica. Mas as suas raízes eram muito antigas" (GINZBURG 1989, p. 151).

Para o autor, esta forma de saber, ou de desvelamento, varia segundo seus contextos e momentos históricos, assemelha-se a uma densa trama que, de acordo com a circunstância, imprime teor venatório, divinatório, indiciário ou semiótico a este paradigma: "Trata-se, como é claro, de adjetivos não sinônimos, que no entanto remetem a um modelo epistemológico comum, articulado em disciplinas diferentes, muitas vezes ligadas entre si, pelo empréstimo de métodos ou termos-chave" (GINZBURG 1989, p. 170) 


\section{"GROUNDED THEORY"}

A idéia da "grounded theory" emergiu na década de sessenta, a partir de discussões provindas das ciências humanas que giravam sobre os méritos relativos à forma quantitativa e qualitativa de pesquisa. Dois autores, BARNEY GLASER e ANSELM STRAUSS foram quem primeiro descreveram esta metodologia em 1967, observaram que a prática sociológica era quase exclusivamente apoiada em métodos quantitativos e estes possuíam mais prestígio que os métodos qualitativos. (HENWOOD 1996; PIDGEON 1996). Ambos escolheram o termo "grounded theory" para expressar "...a idéia de uma teoria que é gerada por (ou fundada em) um interativo processo envolvendo a análise do conteúdo de dados qualitativos obtidos da (contínua) amostragem, advindos de situações concretas, tais como dados não estruturados obtidos através de entrevistas, observação participante ou pesquisas de arquivos." (PIDGEON 1996, p. 76 )

"Grounded theory" é descrita por diferentes autores interessados em desenvolver métodos para a pesquisa qualitativa. (RENNIE, PHILIPS \& QUARTARO,1988; DENZIN \& LINCOLN,1994;)

Em livro intitulado The Discovery of Grounded Theory, Glaser e Strauss, precursores desta metodologia, apresentaram três propostas na constituição desta teoria: a primeira era oferecer os fundamentos da teoria gerada e desenvolvida através da interação dos dados coletados. Glaser e Strauss argumentaram que este tipo de teoria: (....) "contribuiria para 
preencher a embaraçosa lacuna entre teoria e pesquisa empírica" (DENZIN \& LINCOLN, 1994 p.274).

Vale lembrar, que a teoria "grounded" e suas possibilidades, eram propostas que iriam contra o funcionalismo dominante $\mathrm{e}$ as teorias estruturais (STRAUSS \& CORBIN, 1994).

A segunda proposta do livro sugeriu a lógica e as especificidades da teoria. E, o terceiro objetivo, legitimou cuidadosamente a pesquisa qualitativa, já que não a acreditavam capaz de adequada verificação.

O objetivo da "grounded theory" é: (....) "buscar similaridades e diversidades, reunindo uma gama de indicadores que apontem para as múltiplas facetas qualitativas que possuam a potencialidade de gerar um conceito significativo" (PIDGEON \& HENNWOOD 1996, p. 93).

$\mathrm{Na}$ "grounded theory", o procedimento inclui o desenvolvimento de um sistema de codificação aberto e a geração de níveis de categorização para descrever características e conceitos relevantes. Deste modo, uma lista de categorias emerge a partir de uma sistemática inspeção dos dados que implica em uma constante tarefa de comparação.

As operações utilizadas pelo pesquisador para construir este conjunto de categorias são: saturação teórica de categorias, (codificação de exemplos até o ponto em que não mais novos exemplos de codificação sejam encontrados), escrever a descrição das categorias que tenham atingido a saturação, registrar todas as observações feitas pelo pesquisador no curso 
da análise, ligando categorias, e procurando mais dados para elucidar aspectos dos conceitos emergentes (PIDGEON \& HENNWOOD, 1996).

A importância da análise deste tipo de material, escrito e verbal, está na possibilidade da promoção de um maior entendimento de uma experiência subjetiva, uma vez que é construída por meio da linguagem (CARVALHO, 1996).

\section{REPRESENTAÇÕES SOCIAIS}

São muitas as contribuições no campo de estudos das representações sociais: teorias do conhecimento, teorias do funcionamento da mente, teorias sobre práticas sociais, lingüística, entre outros.

O conceito de representação social foi cunhado pelo psicólogo social Serge Moscovici, em 1961 (SÁ, 1996). Na caracterização dos processos formadores das representações, este autor "mostra como a elaboração da representação social implica, necessariamente, um intercâmbio entre intersubjetividades e o coletivo na construção de um saber que não se dá apenas como um processo cognitivo (Piaget), mas que contém aspectos inconscientes (Freud), emocionais e afetivos tanto na produção como na reprodução das Representações Sociais" (LANE, 1993, p. 60).

Representações sociais são produções, individuais ou grupais, do senso comum, saberes cotidianos. Estas produções que SPINK (1994) 
chama "produções de sentido" têm como função a organização do mundo em que se vive e a comunicação.

Sendo a representação, versão da realidade, sua interpretação é a versão da versão, não se busca uma leitura do real, tal como ele é, que pode ser medido e analisado de forma "independente", objetivamente ou ainda, buscando "nexos de causalidade" (BIRMAN,1991; IBAÑEZ, 1993).

No entanto, segundo BIRMAN (1991), estar cuidadoso de que a interpretação é, além de: (....) "instrumento fundamental para a produção de conhecimento", um recorte feito por um "olhar" na realidade, é talvez o primeiro passo em direção a uma perspectiva diferente daquela que a "objetividade" nos coloca como "verdade" (BIRMAN,1991).

Para apoiar as análises interpretativas faz-se necessário a compreensão dos fatores situacionais e do cenário vivido pelas pessoas de onde provêm os discursos. Estes, pautados pela intersubjetividade, estão presos a contextos sociais específicos, segundo SPINK (1994), o contexto é "a justaposição de dois textos: o texto sócio histórico que remete às construções sociais que alimentam nossa subjetividade; e o texto - discurso, versões funcionais constituintes de nossas relações sociais" (SPINK 1994 p.122). Esta articulação pressupõe o tempo presente, onde acontece o contexto necessário à compreensão da atividade de construção das narrativas. 
Desta forma, na adoção do conceito de representação social pressupõe-se a compreensão da interligação e mútua influência entre o pensamento individual, grupal e social.

Os três pressupostos metodológicos apontam que, para se pensar nesta articulação, que se dá em todos os momentos do processo da pesquisa, faz-se necessário o suporte teórico e contextual, para que, entre outras coisas, o pesquisador não submerja e se perca em sua própria subjetividade. Na breve reconstituição histórica, há a tentativa de inserir um macro-contexto que, por vezes, será explicitamente remetido na análise e que muito contribuiu para a compreensão dos discursos, no que se refere às antigas pistas na formação do pensar a maternidade, como também do fazer cotidiano como, por exemplo, a inserção da mulher no trabalho e a conjunção disto às funções maternas. Ou seja, na análise veremos que muitos dos múltiplos aspectos da maternidade têm, se não a sua origem, certamente sua consolidação, em idéias provindas de distintos momentos históricos, de distintos contextos sociais, culturais e políticos, como vimos na Revolução francesa e depois no Brasil Colônia.

Uma vez que a criação das categorias analíticas são fruto da interação entre subjetividades, do ponto de vista do coletivo e do ponto de vista individual, as várias partes do processo de pesquisa se entremeiam e a organização dos discursos, são em si mesmo constituintes do processo de análise, considerando inclusive o recorte interpretativo do pesquisador. 
Ater-se a nuances das entrevistas, lê-las exaustivamente, buscando as diferenças e as recorrências, faz com que na construção e na desconstrução, na união e na separação de categorias, a interpretação já se fizesse fortemente presente. É na organização dos dados que se inicia a análise.

Para a "grounded theory" as categorias são equivalentes a conceitos que se criam. Muito mais do que ser mera questão de nomenclatura, de fato, posicionar-se sob esta perspectiva, muitas vezes indicava os rumos de determinados recortes de discurso: categorias sumiram, ou se fundiram, ou se fortaleceram, dependendo das possibilidades de sustentação do conceito que emergia.

Reconhecer minuciosamente os discursos, compará-los e classificálos exaustivamente são operações envolvidas nos três pressupostos metodológicos. Também ater-se aos tons de voz, aos gestos e outras sutilezas, indicou rumos que protagonizaram "insights" no processo de análise de discurso.

A epistemologia concernente aos três pressupostos teóricos tem sua base nas ciências humanas, até mesmo por serem métodos que intencionam um recorte qualitativo de análise em um momento que, principalmente para a "grounded theory" e representações sociais, havia a necessidade de fortalecimento deste tipo de olhar, contrapondo-se aos métodos mais positivistas. 
Desta forma, o apoio em conceitos da psicologia e da antropologia contribuem para melhor entendimento do fenômeno estudado, ou seja, os discursos e seus significados no mundo em que se apresentam, além de integrar a própria metodologia.

Para os três pressupostos metodológicos é patente a grande importância dada ao contexto da pesquisa. Na perspectiva da representação social este contexto pode incluir aspectos históricos - sociais que, neste trabalho, muito contribuíram para a compreensão dos discursos sobre a maternidade ou a maneira de ser mãe.

A proposta de um método interpretativo que se interessa por detalhes, por dados marginais e resíduos considerados reveladores, tanto pertence ao sistema indiciário como à psicanálise, como demonstra Ginzburg (1991) em seu livro "Mitos, emblemas e sinais". Para a psicanálise, através dos detalhes é possível encontrar elementos que se furtam ao controle da censura e revelam conteúdos de uma atividade inconsciente, são por vezes os detalhes que nos levam a uma fantasia e esta pode indicar algo subjacente ao que está sendo dito.

A seguir veremos como estes aportes foram aplicados ao material empírico. 


\section{PROCEDIMENTOS}

De início houve uma fase piloto, onde várias pessoas foram entrevistadas a propósito do mesmo tema que sempre girava em torno de questões vinculadas à maternidade. Estas pessoas possuíam características diversas como também foram diversas as técnicas de abordagem utilizadas.

Aproveitando uma outra pesquisa que envolvia visitas à domicílio nas favelas do Município do Taboão da Serra, foram feitas algumas perguntas ao grupo de mulheres que estava, então, sendo alvo da outra pesquisa. Elas eram em sua maioria mães, com poucas exceções, mas, todas haviam passado pela experiência da gravidez. Era objetivo, ainda que no começo isso não fosse tão claro, uma sondagem sobre o tema da presente pesquisa e a experimentação do entrevistador enquanto tal. Infelizmente, o registro em áudio deste material se perdeu completamente ficando apenas algumas anotações feitas quando as fitas foram escutadas pela primeira vez. Foram entrevistadas em torno de quarenta mulheres com poucas e breves perguntas, na maior parte das vezes em pé, na porta dos barracos ou em meio à rua/viela. A partir deste ensaio, muitos caminhos de abordagem foram eliminados, outros adotados, as questões foram sendo pensadas, simplificadas, a maneira de falar ficando mais à vontade, sendo utilizada uma linguagem mais direta. Neste momento, foi importante perguntar da 
maneira mais livre possível, de forma que, muito se descobria sobre o que funcionava e o que não, na entrevista. Com esta possibilidade de treino foram proporcionados alguns facilitadores também em termos da maneira de perguntar.

O que estamos chamando de fase piloto correspondeu também, depois desta fase acima relatada, a um convite feito à 12 pessoas para que respondessem por escrito a uma questão. Entre as pessoas haviam mulheres que tinham tido filhos e mulheres que não, além de um homem sem filhos. Eram duas questões: uma indagava sobre o que se pensava sobre gravidez, outra o que se pensava sobre maternidade. Cada uma delas foi dada à metade do grupo, aleatoriamente, ou seja, cada pessoa respondeu a apenas uma questão. Este ensaio contribuiu para fomentar a reflexão entre gravidez e maternidade, além de fornecer a experimentação deste instrumental específico.

Por fim, houve ainda cinco entrevistas em profundidade, com duração entre 40 minutos, a mais breve, e em torno de 1hora e meia a mais demorada, gravadas mediante consentimento do entrevistado. Havia um roteiro temático a ser seguido, mas de forma flexível, muitas vezes outras perguntas se incorporavam e deixou-se o entrevistado desenvolver suas narrativas sem cortes ou redirecionamentos. Este trabalho contribuiu para pensar-se sobre semelhanças e diferenças entre mulheres mais 
intelectualizadas e mulheres menos intelectualizadas, além de, como os outros, avaliar instrumental quanto à pesquisa e pesquisador.

A intenção de todos esses esforços era o de aparar ao máximo as arestas do roteiro de perguntas para chegar à versão definitiva, bem como uma gradativa aproximação do universo a ser pesquisado, possibilitando pistas para posterior procedimento e encaminhamento das entrevistas. Dentro deste procedimento inicial, tínhamos como norteadores pressupostos pertencentes ao sistema indiciário, quando era intuito reunir o máximo de informações do universo a ser pesquisado, aumentando a quantidade de indícios que contribuiriam posteriormente para melhor desvelamento do fenômeno, pressupostos pertencentes a "grounded theory" no que se refere a busca de dados em contínuas amostragens advindas de situações concretas e também pressupostos pertencentes ao conceito de representação social, no que diz respeito as sucessivas aproximações de fatores situacionais e do cenário vivido pelas pessoas de onde provêm o discurso.

Para o grupo estudado no presente trabalho, foram entrevistadas quinze mulheres, na creche "Mãe do Salvador", da seguinte forma: em um primeiro momento, entrevista composta de 5 questões abertas (anexo1), que foram gravadas mediante consentimento. Após um pequeno intervalo de tempo, de aproximadamente um mês, retornou-se a estas mesmas mulheres com novo tipo de entrevista, agora propondo o relato de duas experiências 
específicas, uma que se tratasse de um momento BOM, ou seja, alegre, de contentamento e outro momento RUIM, ou seja, um momento difícil, ruim, ambos vividos junto ao filho (anexo2). Ambas entrevistas encontram-se anexadas, em sua versão integral, ao final deste trabalho.

O propósito desta segunda fase de entrevista era o de estimular respostas que contivessem relatos de experiências concretas, das mães junto aos filhos, e também possibilitar a emergência de vivências mais censuradas, entendidas pelas mães como um momento ruim, relatos que normalmente não apareciam espontaneamente, ou surgiam sutis e recheados de culpa, como observamos na fase piloto e na primeira fase de entrevistas.

As entrevistas foram realizadas em sala cedida pela creche "Mãe do Salvador", com duração de aproximadamente 10 minutos para cada fase, normalmente efetuada pouco antes dos horários de saída ou logo após o horário de entrada das crianças. As condições de privacidade se deram a contento. Em dois casos, a segunda fase da entrevista foi realizada em outro local, uma na própria casa da entrevistada e outra dentro do carro, em frente ao local de seu serviço. Também em dois casos, não foi possível a realização da segunda etapa de entrevista uma vez que estas mães se desligaram da creche, no intervalo de tempo entre uma fase e outra, não deixando paradeiro disponível. 
O tratamento dado às entrevistas, contemplando os três aportes teóricos adotados na metodologia, seguiu os seguintes passos:

1.Transcrição

2.Leituras com atenção flutuante (até a incorporação dos conteúdos)

3. Elaboração de sínteses de cada entrevista com anotações

4. Elaboração horizontal de temas

5. Primeira formulação de categorias

Até o passo três temos indicações, no que tange a um intenso relacionamento do pesquisador com os dados, concernentes aos três pressupostos teóricos adotados pela metodologia deste trabalho.

A elaboração horizontal de temas consistiu em analisar a existência ou não, de menção em todas as entrevistas, de uma variedade de temas percebidos na transcrição, nas leituras, na sintetização e, evidentemente, nas anotações, encaminhando progressivamente, desta forma, a criação das categorias.

A partir deste momento, retomou-se as entrevistas em sua forma integral, uma a uma, para uma análise vertical, sublinhando as categorias encontradas e recorrendo à síntese quando era necessária uma visão geral daquele discurso. Quando novas categorias surgiam, voltava-se às entrevistas lidas, verificando sua existência ou ausência. A organização de dados com forma horizontal e vertical de leitura, assim com a formulação de 
sínteses, são recursos técnicos recorridos por pesquisas inseridas na área das representações sociais (BOCK, 1993), como também de pesquisas na área da "grounded theory" (PIDGEON \& HENWOOD, 1996).

Para tal, dentro de procedimento incluído na "grounded theory", foi feita uma saturação destas categorias, com codificação de exemplos pertencentes a estas, de forma que nenhum exemplo restasse fora de sua categoria, a transferência ou a concomitância de narrativas de uma categoria para outra. Estas categorias foram nomeadas e agrupadas a partir de comparações entre as falas que tratavam de dar conta de um mesmo assunto (PIDGEON \& HENWOOD, 1996).

A seguir, foi feita uma subdivisão dentro de cada um destes agrupamentos, através também da observação das semelhanças e diferenças, no conteúdo das falas pertencentes a uma determinada categoria. Esta técnica é empregada tanto em estudos das representações sociais (SPINK, 1994), como em estudos desenvolvidos sob a ótica da "grounded theory" (PIDGEON \& HENWOOD, 1996).

Posteriormente, foram escritas as definições de cada categoria, ou seja, que aspectos envolvem e contêm determinada categoria.

As anotações do pesquisador foram balizadas com as categorias criadas, como também as possibilidades de ligações das categorias entre si, muitas vezes envolvendo a criação de novas categorias e a transformação de outras (PIDGEON \& HENWOOD, 1996). 
Chegamos, após todo o percurso descrito, ao número de oito categorias, com a seguinte nomeação:

O PLENO

MÃE BOA, MÃE MÁ

MÃE SIM, ESPOSA NÃO

EDUCAÇÃO

RESPONSABILIDADE E TRABALHO

UM MAU MOMENTO

UM BOM MOMENTO

TRANSFORMAÇÃO OU MANUTENÇÃO?

Nas análises dos resultados de cada categoria falaremos no que consiste e de onde vem cada nomeação.

Durante todo o processo, buscou-se mais dados, à medida que isso se fez necessário, como por exemplo, o tipo de trabalho e o conseqüente salário das entrevistadas. Tantas vezes quanto necessárias, voltou-se às entrevistas, em sua forma integral ou sintetizada, ou ainda nos agrupamentos horizontais onde continha todas as menções sobre determinado tema, por todas as entrevistadas.

A idéia chave contida nos passos anteriores é a de uma constante análise comparativa dos dados entre si, e dos dados e anotações do pesquisador (PIDGEON \&HENWOOD, 1996). 
Por fim, a elaboração de comentários analíticos, onde dá-se a reflexão propriamente dita do trabalho, e a necessária busca de aportes teóricos que auxiliassem a sustentação destes comentários, as interpretações, bem como a compreensão do fenômeno estudado.

\section{SITUANDO OS SUJEITOS}

Através da Superintendência Regional do Bem Estar, (SURBES) Butantã/Pinheiros, foi obtida a listagem de equipamentos, creches, da região de Pinheiros.

Esta região foi escolhida para a pesquisa de campo pelo fato de estar próxima ao Centro de Saúde Escola "Geraldo de Paula Souza", que é vinculado à Faculdade de Saúde Pública, facilitando, no futuro, uma contribuição efetiva dos resultados para com o serviço. Além do que, a proximidade facilitaria as freqüentes idas à creche, compatibilizando os horários da instituição e das entrevistadas, contemplando ambas conveniências.

A listagem que continha os programas de assistência à criança dividese da seguinte forma: creche indireta, creche conveniada, centro da juventude indireto e centro da juventude conveniado. A diferença entre unidade indireta e unidade conveniada é que na primeira, o prédio pertence à Prefeitura e na segunda, o prédio pertence a uma entidade filantrópica, contudo, os contratos de ambas são feitos pelas entidades, o pagamento 
mínimo e instalações pela Prefeitura e gastos complementares subsidiados pelas entidades e doações.

A creche visitada foi uma creche indireta chamada "Mãe do Salvador". A diretora da creche prontificou-se a auxiliar nosso trabalho, permitindo a ajuda da orientadora pedagógica para a identificação dos grupos que possuíam crianças que eram filhos únicos. A partir daí, foi feito o levantamento das fichas de cada criança que possuísse uma mãe interessante à este trabalho. Vale dizer, que a receptividade por parte da direção e dos funcionários da creche, foi extremamente boa, disponibilizando os recursos materiais e humanos para o necessário. Tudo acertado para o encaminhamento da pesquisa, a orientadora pedagógica começou a ajudar, nos intervalos de tempo que the eram convenientes, a levantar as fichas mencionadas. Este processo de seleção durou alguns dias o que tornou possível algum convívio inserido no cotidiano da creche, promovendo uma compreensão de seu ritmo como também, o conhecimento de sua clientela e o relacionamento desta com a equipe pedagógica. De modo que foi possível observar que as mães possuíam, de fato, uma referência na orientadora pedagógica, buscando-a freqüentemente para tirar dúvidas, solicitar orientações, promover eventos em conjunto, entre outras coisas. Percebiase que tinham certa liberdade e confiança na orientadora.

Para a triagem das fichas, as mães deveriam então se enquadrarem dentro das características previamente estabelecidas, a saber: mães com 
menos de 24 anos, com apenas um filho (a), este não apresentando qualquer elemento fora do padrão de "normalidade". As mães deveriam ser primíparas, que utilizavam serviços públicos e não se encontrassem grávidas, no momento da entrevista.

Mães de até 24 anos por dois motivos: primeiro pelo fato de ser a idade de limite máximo estabelecida pela Organização Mundial de Saúde, para designar a juventude, que compreende a adolescência que se insere nas idades entre 10 e 20 anos e o jovem, que se insere na idade entre 14 a 24 anos. E, segundo, pelo fato de que mães mais velhas não eram mais mães de um só filho, como constatamos nas fichas levantadas. É importante dizer que foi pesquisada a totalidade das mulheres que possuíam as características arroladas e que pertenciam ao universo escolhido.

A escolha por mães de filhos únicos foi apoiada na consideração, vista na fase piloto e discutida em orientação, de que mães de vários filhos possuíam uma lida mais funcional na criação destes e, muitas vezes, achavam comuns e/ou corriqueiras muitas situações que se apresentavam mais complicadas para a mãe de um só filho, pelo fato desta estar em processo de acomodação dos diversos aspectos que englobam a maternidade. A opção por não entrevistar mães de filhos com doenças graves ou portadores de deficiência foi devido consideração que seria muito possível que estas hiperbolizassem alguns aspectos, como o de cuidados à saúde. O fato de as mulheres serem mães e não estarem no momento 
grávidas adveio da intenção de buscar respostas que teriam como base a experiência concreta da maternidade, evitando também conjecturas, por exemplo econômicas, estimuladas e relacionadas eminentemente pela vinda de um futuro bebê.

A orientadora pedagógica da creche contribuiu também no sentido de conversar previamente com as mães escolhidas, explicar-lhes de maneira simples o estudo que seria feito e como, para isto, seria necessário que respondessem algumas perguntas que seriam feitas pela pesquisadora. $\mathrm{A}$ esta mesma orientadora coube o agendamento dos horários das entrevistas, que seriam realizadas na própria creche, gravadas sob consentimento livre e esclarecido, em sala para este fim cedida, e respeitando-se a conveniência de horários das mães. Vale ressaltar, que esta ajuda por parte da diretora e da orientadora da creche fez-se de grande valia não apenas no aspecto logístico e funcional, mas também no aspecto afetivo, uma vez que minha inserção foi através de vínculo já estabelecido, de confiança, promovendo desta forma facilidades na relação entrevistadora/entrevistanda.

Das quinze mulheres entrevistadas, seis estavam com vinte e dois anos, quatro com vinte e quatro anos, três com vinte e três anos, uma com dezoito e uma com dezessete anos no momento da entrevista. Oito delas eram empregadas domésticas, e duas eram auxiliares de desenvolvimento infantil, um cargo existente em creches públicas. As cinco restantes tinham ocupações variadas: uma era vendedora, uma recepcionista, uma babá, 
uma que trabalhava com o marido em pequeno comércio, e uma que não estava trabalhando no momento da entrevista. O salário destas mulheres tinha como média o valor de dois salários mínimos aproximadamente, sendo que cinco delas ganhavam $\operatorname{Cr} \$ 200$ reais, duas nada recebiam, apenas uma tinha $\mathrm{Cr} \$ 650$ reais de ganho e o restante recebia em torno de $\mathrm{R} \$ 300$ reais.

Algumas jovens (4), todas domésticas, moravam com o filho, no mesmo local em que trabalhavam, com exceção de uma (a babá) que tinha seu filho morando com sua mãe. Isto explica os endereços em bairros nobres na cidade. As restantes, em sua maioria, moravam em localidades bastante distantes da creche. Com relação a esta última informação, pensou-se que isto poderia ser devido ao seu serviço (ou de seu companheiro) ser perto da creche, ou também pelo fato destas mães considerarem a creche em questão mais apropriada do que as creches existentes próximas ao seu local de moradia.

A situação conjugal é bastante variada, nove delas viviam com o companheiro no momento da entrevista, e entre estas havia as que tinham e que não tinham sua união formalizada. Quatro não tinham companheiro, uma era viúva e morava com sua sogra, que a ajudava financeiramente. Apenas cinco mães eram mães de meninas e dez eram mães de meninos.

Para a preservação da identidade dos sujeitos entrevistados, todos os nomes são fictícios. 
QUADRO 1. PERFIL DAS ENTREVISTADAS QUE TÊM SEUS FILHOS NA CRECHE

"MÃE DO SALVADOR"

\begin{tabular}{|c|c|c|c|c|c|c|}
\hline Nome & Idade & Bairro & $\begin{array}{l}\text { Sexo/ } \\
\text { idade } \\
\text { filho(a) }\end{array}$ & Sit. conjugal & Ocupação & $\begin{array}{l}\text { Salário } \\
\text { reais }\end{array}$ \\
\hline $\begin{array}{l}\text { Maria das } \\
\text { Graças }\end{array}$ & 22 & $\begin{array}{l}\text { A. de Pinheiros } \\
\text { (serviço) }\end{array}$ & $\begin{array}{l}\text { Masc. } \\
03\end{array}$ & s/companheiro & Babá & $\$ 300$ \\
\hline Maria José & 23 & V. Madalena. & $\begin{array}{l}\text { Fem. } \\
2,11\end{array}$ & c/ companheiro & Recepcionista & $\$ 250$ \\
\hline $\begin{array}{l}\text { Maria do } \\
\text { Amparo }\end{array}$ & 24 & $\begin{array}{l}\text { Pinheiros } \\
\text { (serviço) }\end{array}$ & $\begin{array}{l}\text { Masc. } \\
2,6\end{array}$ & s/companheiro & Doméstica & $\$ 200$ \\
\hline $\begin{array}{l}\text { Maria do } \\
\text { Socorro }\end{array}$ & 24 & \begin{tabular}{|lll} 
Jdm. & Novo & Campo \\
Limpo & & \\
\end{tabular} & $\begin{array}{l}\text { Masc. } \\
3,4\end{array}$ & c/companheiro & Doméstica & $\$ 250$ \\
\hline $\begin{array}{l}\text { Maria de } \\
\text { Fátima }\end{array}$ & 22 & Taboão da Serra & $\begin{array}{l}\text { Masc. } \\
03\end{array}$ & $\begin{array}{l}\text { s/companheiro } \\
\text { (viúva) }\end{array}$ & Doméstica & $\$ 200$ \\
\hline $\begin{array}{l}\text { Maria } \\
\text { Teresa }\end{array}$ & 24 & Vila Beatriz & $\begin{array}{l}\text { Masc. } \\
03\end{array}$ & c/ companheiro & $\mathrm{ADI}^{*}$ & $\$ 380$ \\
\hline $\begin{array}{l}\text { Maria } \\
\text { Anastácia }\end{array}$ & 22 & $\begin{array}{l}\text { A. de Pinheiros } \\
\text { (serviço) }\end{array}$ & $\begin{array}{l}\text { Masc. } \\
8 \mathrm{~m}\end{array}$ & c/companheiro & Doméstica & $\$ 200$ \\
\hline $\begin{array}{l}\text { Maria do } \\
\text { Carmo }\end{array}$ & 22 & & $\begin{array}{l}\text { Masc. } \\
01\end{array}$ & c/ companheiro & Doméstica & $\$ 200$ \\
\hline $\begin{array}{l}\text { Maria de } \\
\text { Lourdes }\end{array}$ & 23 & Embu das Artes & $\begin{array}{l}\text { Fem. } \\
02\end{array}$ & s/ companheiro & Doméstica & $\$ 650$ \\
\hline $\begin{array}{l}\text { Maria dos } \\
\text { Remédios }\end{array}$ & 22 & Taboão da Serra & $\begin{array}{l}\text { Fem } \\
02\end{array}$ & c/companheiro & do lar & ------ \\
\hline $\begin{array}{l}\text { Maria } \\
\text { Madalena }\end{array}$ & 23 & Vila Beatriz & $\begin{array}{l}\text { Fem. } \\
02\end{array}$ & c/ companheiro & c/marido & ----- \\
\hline $\begin{array}{l}\text { Maria da } \\
\text { Conceição }\end{array}$ & 24 & $\begin{array}{l}\text { A. de Pinheiros } \\
\text { (serviço) }\end{array}$ & $\begin{array}{l}\text { Masc. } \\
2,4\end{array}$ & s/ companheiro & Doméstica & $\$ 350$ \\
\hline Maria & 17 & Campo Limpo & Masc. & s/ companheiro & Doméstica & $\$ 112$ \\
\hline
\end{tabular}


CAPÍTULO III - METODOLOGIA

\begin{tabular}{|l|c|l|l|l|l|c|}
\hline Imaculada & & & $6 \mathrm{~m}$ & & & \\
\hline $\begin{array}{l}\text { Maria } \\
\text { Aparecida }\end{array}$ & 22 & Capão Redondo & $\begin{array}{l}\text { Fem. } \\
02\end{array}$ & c/companheiro & Vendedora & $\$ 200$ \\
\hline Maria Goret & 18 & Interlagos & $\begin{array}{l}\text { Masc. } \\
01\end{array}$ & c/companheiro & ADI* & $\$ 380$ \\
\hline
\end{tabular}

${ }^{*}$ Auxiliar de desenvolvimento infantil (em creche pública) 


\section{O PLENO}

Nomear de "pleno" esta categoria, foi escolha devido à definição mesma da palavra. Segundo a definição encontrada em FERREIRA (1996), o nosso conhecido "Aurélio", pleno significa: 1. Cheio, repleto. 2. Completo, inteiro, absoluto, cabal.

Ou seja, quando algo ou alguém é ou está pleno, é ou está repleto de alguma coisa.

A partir das narrativas, foram agrupadas as falas que continham uma idéia de mãe que surgia, no geral, preenchida de aspectos plenos, estes contudo, de natureza distinta entre si.

Frases que rigorosamente não explicam nada per si, devendo possuir um referencial que possua elementos comuns no que se pensa sobre ser mãe, para a compreensão de um implícito embutido na frase. Frases como:

\section{(....) mãe é sempre mãe}

Este referencial de elementos comuns pode existir sob a aparência de simples ditos populares dos quais ninguém questiona, deixa de usar ou deixa de compreender.

GRISCI (1995), que realizou pesquisa sobre como a ideologia opera estratégias de ação que interpelam a mulher/mãe, fala em seu trabalho 
sobre a freqüência e naturalidade com que os ditos populares sobre o papel da mãe são pronunciados e a imobilidade que provocam, o que lhes delega um caráter de obviedade. "Essa idéia de eternalização mostra-se como um campo profícuo a amparar a ideologia enquanto mantenedora de uma subjetividade de mulher mãe" (GRISCI 1995, p. 13).

Por outro lado, há um indício na frase "mãe é sempre mãe" que pode ser continente ao que estamos chamando de pleno que denuncia-se na palavra "sempre" e que nos remete a uma noção de tempo. Algo que não teve princípio e não há de ter fim. Assim, isto que significa mãe, o é todo o tempo, em qualquer ocasião, portanto, é absolutamente preenchido de tempo e por isso mesmo, atemporal. Em qualquer tempo, em qualquer momento histórico ou do cotidiano, ou mesmo em qualquer idade, enfim, em todos os tempos ser mãe se refere à mesma configuração de sentimentos ações e gestos; "mãe é sempre mãe" o que, vimos em capítulos anteriores, isto nem sempre é verdadeiro.

Da mesma maneira observamos este tipo de plenitude quando analisamos as frases:

(....) mãe é sempre a mesma

(....) mãe continua a mesma

(....) mãe é a vida toda 
Nesta última afirmação, podemos pensar que há uma referência à vida no geral, à vida que existe ao redor, indicando também relação com todos os tempos. Por outro lado, podemos pensar nos diversos papéis sociais que são assumidos pelo sujeito ao longo de sua vida, e que são papéis passíveis de mudança, o que, certamente, não diz respeito ao papel de mãe.

(....) uma mulher quando... dá pra ser mãe, é a vida toda.

Além do que, tornando o espaço de tempo extensível à vida de todas as mulheres que foram e são mães e novamente marcando o caráter pleno de tempo.

Algumas mães usam palavras que denotam uma grande valorização e intensidade no que pensam ou sentem sobre ser mãe:

Mãe tolera mesmo.

Eu adoro ser mãe.

É maravilhoso, é a melhor coisa do mundo.

Ser mãe é tudo.

Minha filha é tudo para mim, mãe é mãe.

(....) ser mãe é uma coisa muito boa. 
Temos a indulgência (a tolerância), o amor imoderado (a adoração), o admirável (maravilhamento), o absoluto (tudo) e a abundância (muito boa) que são expressões que resvalam, quando não submergem, no incondicional, naquilo que excede. Não obstante, de forma menos superlativa, trazem a seguir algo da ordem das dificuldades que encontram em seu cotidiano. Colocaremos na mesma ordem das frases anteriores para que se possa perceber o que foi dito pela mesma mãe: a mãe que disse que se "tolera mais" (hoje), acha que é porque os tempos mudaram, diz que:

(....) acho que mudou bastante, mudou um pouco, eu acho, esse ritmo... mãe continua a mesma mas esse ritmo de antigamente e de hoje em dia.. acho que mudou um pouco, viu?

E as seguintes:

(....) é muito difícil, pela vida que a gente tem hoje, mas que é bom, é, ser mãe.

(....) apesar dos trabalhinhos que dá, né, mas...é, eu acho que é muito bom (....)

(....) apesar de tudo, né, porque meu filho é muito... de vez em quando tem que levar ele no médico, quase sempre, né, ele está sempre doente, quase, mas...está em primeiro lugar pra mim.

(....) porque sempre ele dá alegria pra gente, né, tem hora de trabalho e hora de alegrias também. 
É curioso notar que, juntando às afirmações anteriores, onde generalizavam e exageravam o sentido do ser mãe, estas, que vieram logo a seguir, tratam dos problemas que enfrentam no dia a dia e estes dão um caráter mais singular, mais personificado e menos idealizado, redimensionando a vida de cada entrevistada. Contudo, estas últimas frases parecem vir mais para dar sustentação à intensidade das frases anteriores sobre ser mãe como se as dificuldades cotidianas só reiterassem o amor pelo filho (a); como se falasse de uma força, uma manutenção da intensidade no ser mãe não obstante os obstáculos cotidianos, tratam do "apesar de" muito mais para corroborar o genérico do que para apresentar a particularidade.

Para HELLER (1970), o que chama de ultrageneralização é imprescindível da vida cotidiana, uma vez que nas ações no dia a dia, o singular tende a ficar sob alguma universalidade, como uma forma de organização do cotidiano e dos problemas que nele enfrentamos.

De duas maneiras chegamos à ultrageneralização característica de nosso pensamento e de nosso comportamento cotidianos: por um lado, assumimos estereótipos, analogias e esquemas já elaborados; por outro eles nos são 'impingidos' pelo meio em que crescemos e pode-se passar muito tempo até percebermos com atitude 
crítica esses esquemas recebidos, se é que chega a produzir-

se uma tal atitude (HELLER 1970, p. 44)

Há três mães que colocam na maternidade a condição para ser sujeito inteiro, pleno:

É a coisa mais bonita do mundo. Tudo que a gente pode...tudo que a gente pode...é...gerar um filho, sabe, é a coisa mais bonita, assim...para uma mulher

(....) olha, ser mãe é maravilhoso (....) a gente se torna, assim, importante, a gente dá mais valor à vida

(....) acho que a vida, com filho, é necessário pra a pessoa, né

(....) a gente como mulher, ter o filho pra - pra a gente, né,(....) a gente é mais mãe

Esta última disse anteriormente, se referindo ao que há de mais importante em sua vida, o seguinte:

(....) a minha filha, né, porque depois que eu tive ela, a gente tem um sentido, né.

A função materna aqui parece se constituir no núcleo central do ser mulher, ou seja, é na maternidade que está a possibilidade da mulher se realizar plenamente enquanto sujeito inteiro e, não ser mãe, é ser vazio de sua potência, de sua importância (também do valor que se dá para a vida) e de sentido na vida. 
Para GRISCI (1995) o desenvolvimento feminino, desde a infância, é norteado por um condicionamento para o modelo de mãe.

CHODOROW (1990), considera que inúmeros elementos influenciam a capacitação, a assunção e a satisfação das mulheres para o papel de mãe. Coloca que a subjetividade é plasmada paulatina e continuamente por amplo conjunto de fatores.

No capítulo Brasil: a casa os filhos, o sustento, discutimos como, no sul do país, o papel idealizado para a mulher não fora criado pelos jornais, que este modelo já fazia parte do imaginário ocidental, já profundamente arraigado nas mentalidades.

Vimos anteriormente também, como a separação entre o espaço público e privado, definiu também a forma de ser da mulher nas sociedades ocidentais que, nos últimos duzentos, anos, ser mãe foi o principal, senão único, desígnio da mulher e que, a maneira de ser mãe depende profundamente dos valores e interesses configurados em cada período.

As falas:

(....) tem que estar preparada para ser mãe(....) é tanta coisa, né (....) ah, tem mais coisas, s-só que na hora a gente, agá, nem... pensa (....)

(....) acho que ser mãe é um todo (....) ah, ser mãe é educar, é cuidar, é criar dar o melhor de si, sabe, é ver crescer, é tá junto... 
Ambas falam que a maternidade é repleta de coisas; a primeira se refere a uma preparação que podemos suspeitar pertencer ao universo do conhecimento, já que coloca em outro momento da entrevista que para educar um filho:

\section{(....) tem que...saber (....)}

Vários autores escreveram sobre os meios de comunicação em massa e os modelos femininos. (PIRES 1996, GRISCI 1995; NOVELINO 1990; KITZINGER 1978). PIRES (1996), critica em seu artigo aquela interpretação que considera a imprensa como mero reprodutor de informações, valores e comportamentos em nossa sociedade.

Uma das maneiras de divulgação dos modelos de maternidade é através da imprensa e, nas revistas, o tema maternidade é recorrente. KITZINGER (1978), aponta para uma fatia de especialistas escrevendo e aconselhando, de acordo com modismos, a forma que se deve ter, criar e educar os filhos e que há embutida aí, uma perspectiva de que as mães não são preparadas para desempenharem suas tarefas, o que, muitas vezes, desperta culpa e angústia nestas. O outro extremo desta perspectiva é a idéia de que a mulher é dotada de um saber específico, "natural", que, a um "clic" a orienta no desempenho destas tarefas. 
Outra entrevistada fala sobre um "todo" e este parece se aproximar mais de um senso repleto de doação.

Tais falas aqui reunidas, de uma maneira geral, trazem a idéia da maternidade como destino natural e inevitável para a mulher, esta perspectiva está profundamente arraigada nos discursos e consequentemente no pensar destas mulheres. A presença de algo que pertence ao incondicional, que existe em todas as frases aqui arroladas, portanto em todos os discursos, tem sua expressão maior no amor pelo filho, sempre inquestionável e inerente à condição de mãe, sempre gerando necessariamente alegria e satisfação, e sempre sendo o lastro principal da relação mãe/filho. Não é dizer que este sentimento não existia e foi puramente fabricado, ao contrário consideramos que toda expressão de amor construída pelo convívio e através do relacionamento, é legítima, porém, a exaltação deste amor como valor natural, inato à natureza feminina, é o que inferimos ser algo paulatinamente fabricado.

"Ser mulher está biológica e socialmente tão relacionado ao ser mãe que se caracteriza quase uma heresia pensar a mulher mãe como binômio de uma construção . E é também esse o sentido da ideologia "(GRISCI 995, p. 14).

Ou seja, esta automação ao dizer frases que resvalam no dito popular, são idéias tão profundamente arraigadas em nosso pensamento que não se faz mais necessário pensá-las quando as pronunciamos, 
possuem este sentido ideológico que bem observamos neste componente de plenitude ligado à idéia de mãe. 


\section{MÃE BOA, MÃE MÁ}

$\mathrm{Na}$ fase piloto deste estudo, observamos que emoções que possuíssem o mais leve traço hostil não apareciam nos discursos das várias pessoas entrevistadas sobre o assunto da maternidade. Com o grupo entrevistado para esta pesquisa, com exceção das menções a propósito do cansaço na lida com o trabalho simultaneamente à lida com o filho, estes sentimentos não apareceram de maneira direta.

Todo o indivíduo comum já experimentou e manifestou estes sentimentos mesmo quando não os percebe tão claramente em si mesmo, por outro lado, sabemos que nossa sociedade controla os sentimentos de agressividade, mau humor, egoísmo e tantos outros chamados sentimentos negativos. Mesmo não entrando no mérito das implicações desta dinâmica, faz-se compreensível a ausência, ou a não consciência, destes sentimentos pelas mães em suas narrativas, principalmente quando se trata da relação com o seu filho.

A referência ao abandono e a rejeição surgiu em falas de várias mães de maneira peculiar. As mães referendam que outras mães, que não elas mesmas, eram capazes e optaram por abandonarem seus filhos.

(...) É...colocaram uma criança, né, numa porta e... uma, assim, uma... uma patroa que pegou, né, pra, para criar a criança, entendeu? 
(....) porque tem mães que não, não dá muito importância para os filhos, né, tem filho, mas deixa por aí, com qualquer um (....)

(....)Tem umas que, é... deixa de mão, não liga mais (....)

(....) vão fazendo, vai o que der na cabeça só fazendo... e aí, as vezes, vem uma criança indesejável, indesejada, que a mãe as vezes dá, joga fora como acontece muito, né (....)

Podemos pensar que estas mães projetam no outro aquilo que temem ver em si mesmas, no caso a idéia de abandono, pois tais sensações provocariam sofrimento. Este "algo" que não se quer encontrar dentro de si, não precisa ser o desejo de abandono, mas pode ser algo que represente para o sujeito, mesmo que sutilmente, este desejo.

"Através desse processo, todas as sensações ou sentimentos penosos ou desagradáveis existentes na mente são automaticamente banidos para fora de nós; admitimos que se localizem em outra parte que não em nós" (KLEIN 1995, p. 25).

É de se reiterar que não estamos dizendo com isto que há, necessariamente, um desejo recôndito nestas mães de abandonarem seus filhos e sim que é possível ocorrer sentimentos que não sejam tão "bondosos" com relação ao filho, ou à vida que se leva, e isto não significar que esta mãe é um poço de desumanidade. Parece, no entanto, que para essa mãe, estes sentimentos são ameaçadores, isto pode fazer com que 
tome medidas de segurança contra sensações de sofrimento ou desamparo e, da possibilidade de ataque de si mesma e de seu entorno social.

MOREIRA (1993), escreve um livro-depoimento intitulado "Maternidade" onde é bem ilustrativo dos inúmeros e variados sentimentos que vão acontecendo na construção da relação com um filho: "(...) Se deixassem, parava a vida só para ficar com o menino. Eu não. Até hoje gosto de curtir o André, mas não o tempo todo. Isto me frustra muito" (MOREIRA, 1993, p. 35).

No contexto do discurso, "a mãe que abandona", é exatamente aquilo que a descaracteriza enquanto mãe, é a "não-mãe", marca-se assim, uma diferenciação entre ela, entrevistada, e as outras, as quais menciona. Vale ressaltar, que todo o grupo entrevistado considera seu filho(a) o que há de mais importante em sua vida.

$\mathrm{Na}$ escuta das fitas, foi possível observar que as frases que se referiam às mães que abandonavam, negligenciavam e não valorizavam seus filhos, eram ditas em tom crítico, de repúdio e de desprezo. A aparente resistência em mencionar momentos desagradáveis pode indicar uma ação projetiva com relação aqueles sentimentos que não são tão bem aceitos pela própria mãe. Por outra parte, se as idéias que se ligam a abandono se ligam à idéia da "não mãe", assumir tais traços pode implicar em negar componente fundamental da identidade feminina e, consequentemente, da própria identidade. 
"Tendo logrado dessa forma, em nossas mentes, localizar e concentrar o perigo que nos ameaça de fora, passamos então à próxima medida projetiva, que consiste em descarregar os impulsos agressivos que existem dentro de nós sob a forma de ataque a este perigo localizado externamente" (KLEIN 1995, p. 27).

BADINTER (1985), em seu capítulo intitulado "Retrato de mães más" descreve que o inverso da boa mãe é aquela que é 'ausente, incapaz ou indigna' e que, entre estes dois personagens, a boa e a má mãe, cada imagem é absoluta, não há nível intermediário possível. Para nossas mães, parece também não haver termo possível de negociação entre o que considera propriedade da boa mãe e propriedade da má mãe.

Uma mãe localiza em si mesma, ter ocorrido, por um momento, o pensamento da rejeição, foi no momento da sua gravidez e devido a conflitos que passava junto à sua família ascendente. Coloca em seguida que, passado este momento, e com a maternidade, percebeu não ser este seu desejo.

(....) Então eu tinha acabado de voltar a falar com meu pai, meu pai não aceitava muito bem meu namoro, né, então, que qui aconteceu, eu fiquei super nervosa, tal e até quis tirar, a Lia (nome fictício), né, e eu chequei a ir atrás de clínica, para fazer isso, tá, chorava, ele chorava, que a gente tava - o medo era o pai, entendeu?

(....) porque depois que a gente tem fi- uma criança, a gente vê o que qui a gente ia fazer, entendeu? 
A mesma entrevistada, a seguir, faz a diferenciação que mencionamos:

(....) Ah, mas não vai ficar grávida, né a gente não tá nem aí mesmo, então vou tirar fora, que é assim que fazem, né, então falaria isso, ou pensa bem o que qui você tá fazendo. Sabe?

Há outra mãe que diz que se pudesse optar, não teria tido filho (na categoria "Mãe sim, esposa não", esta mesma entrevistada faz nova menção sobre o assunto), mas em seguida traz uma contradição:

Assim se, se eu fosse, se eu pudesse, eu não teria. Eu num voltaria atrás, né.

E, diz também:

Para a maioria. Para a maioria das mulheres um filho é muito importante, tá, porque eu tenho, assim, né experiências, assim, de pessoas, assim, que tem filhos mas não dá aquele valor que a criança devia ter.

(....) Se achar que deve, vai fazendo, vai pondo filhos no mundo, maltratando muito as crianças...

Dá a entender que outras pessoas, outra mulheres, que não ela, não dão o valor e os bons cuidados que uma criança merece e que uma boa mãe oferece.

A idéia de abandono é, como vimos, uma idéia presente no discurso das mães, insurge de seu discurso, deslocado do sujeito que narra e, 
supostamente projetado, para falar da diferença que há entre ela própria e as mães que não consideram importante o seu filho(a). Isto pode nos levar à suspeita de que aqui ocorre um conflito, que podemos chamar de um conflito manifestamente resolvido, uma vez que não há a assunção da ação de abandono pelas entrevistadas.

Voltamos a dizer, não se trata aqui de fomentar o abandono, a displicência e os maus tratos, se trata de questionar se, sentimentos como raiva, enfado, arrependimento, ciúmes e outros, não existem realmente em momento algum no dia a dia com a criança. Ou, se é possível tê-los e não exercê-los, ao menos de maneira extrema. Podemos inferir, com apoio na não menção destes sentimentos do sujeito com relação à criança, que existe a fantasia de que estes só podem existir de maneira extrema, o que torna a consciência de tê-los, insuportável. Pode existir a fantasia de que estes sentimentos necessariamente nos levam à realização de atos concretos, ou ainda, que os dizendo poderão ser interpretados como algo extremo e de possível realização.

Diferenciar-se é ser diferente daquelas que não amam seus filhos.

Olha, eu não sei, eu tô falando só a minha parte. Porque tem muita gente que.. não gosta da mãe, não gosta dos pais. Tem muitas mães mesmo, que não gosta do filho, porque tem mãe que bate, é.. machuca as crianças, então essas mães não gostam do filho, né.

Ou daquelas que perderam o juízo: 
Muitas faz... sei lá se joga do prédio, faz loucuras, joga até as crianças, né (....)

A preferência por um dos filhos e a maneira de ser mãe hoje em dia, também foi apontado como uma insensibilidade com relação ao filho.

(....) tem algumas não, que já num importa tanto (....)

Tem mãe que não gosta do próprio filho, entendeu, não tem...essa...hoje em dia o...uma mãe ela já é meia... sabe, meia- não tem aquela- tanta preocupação, assim, com o filhocertos filhos elas têm, certos, não- alguns não. é isso...pra $\operatorname{mim} \ldots(\ldots .$.

Esta fala contém também uma generalidade, a despreocupação, que parece ser interpretada pela entrevistada como displicência, displicência esta que estaria em todas as mulheres de hoje em dia, ou seja, é o hoje em dia que determina a maneira de ser mãe, maneira esta displicente, despreocupada. Retomaremos esta fala na categoria transformação ou manutenção.

Em seu artigo "Adoção: da maternidade à maternagem”, SANTOS (1998), discute os motivos que impossibilitam muitas mães de manterem ao seu lado o filho e da pressão social para que as mães assumam seus filhos, não obstante o descaso das políticas sociais. Discorre a autora, que esta pressão, além de poder trazer prejuízos para a própria criança, tem por trás um discurso moralizador que cobra um perfil idealizado de mulher. 
A vergonha e o medo de desafiar este mito e a pressão social dele decorrente têm levado muitas mulheres a preferir abandonar sorrateiramente suas crianças em portas alheias, em latas de lixo e em locais os mais variados a fim de não ter que abrir mão voluntariamente do pátrio poder, tornando, assim, pública a sua ausência de (instinto materno?) condição material e/ou afetiva para exercer a maternagem (SANTOS 1998, p. 103).

Por outro lado, como vimos em capítulo anterior, a religião é um dos tantos instrumentos sociais que enseja o controle de sentimentos agressivos e/ou egoísticos, certamente contribui para este perfil idealizado de mulher e de como devem sempre ser os sentimentos de uma mãe para seu filho:

(...) despontou com o Cristianismo, tornando-se uma das grandes religiões do mundo, era em grande parte uma tentativa suprema de dissociar do amor todo o caráter de agressividade e voracidade. Isto foi tentado através da exaltação do amor altruístico a uma posição ideal, ao mesmo tempo negando a realidade de diversos problemas que fazem parte da vida da alma- da psicologia humana. Os impulsos agressivos e sexuais, conquanto sua existência não fosse totalmente negada, eram desprezados e condenados, ou ignorados ( KLEIN 1995, p. 73). 
Todas essas coisas podem estar levando esta mãe a negar em si tudo aquilo que compreende como sendo alheio ao pensamento e comportamento da mãe dedicada, e esta é a única que ama verdadeiramente seu filho, a única que merece o respeito e admiração das pessoas de bem. 


\section{MÃE SIM, ESPOSA, NÃO}

Esta categoria foi criada devido às menções sobre a presença ou ausência de um companheiro, e a oposição entre ser casada, com filho, ou solteira, com filho, além das responsabilidades que são decorrentes destas situações.

O que chamou a atenção foi o fato de que quando estas mulheres mencionam a falta de um companheiro, parecem falar, implicitamente, sob a perspectiva de possuir ou não uma família, dentro da acepção burguesa de família.

ARIÈS (1978), em seu minucioso trabalho sobre a família e a criança, verificou o surgimento de um novo sentimento: o sentimento de família. Descreve que a família transformou-se substancialmente a partir das mudanças no relacionamento com a criança. Observou que a família do século XVII, que, importante salientar, ainda não é o que chama de família moderna, começa a ter, como um de seus traços fundamentais, a ternura e intimidade ligando pais e filhos e, posteriormente, a exaltação do amor materno, de enorme importância para a criação do sentimento de família como o entendemos atualmente: (....) "a família moderna, ao contrário, separa-se do mundo e opõe à sociedade o grupo solitário dos pais e filhos. Toda a energia do grupo é consumida na promoção das crianças (....) A partir do séc. XVIII, e até nossos dias, o sentimento de família modificou-se muito pouco" (ARIĖS 1978, p. 271). 
A Revolução Francesa, que subverteu a fronteira entre o público e o privado vem transformar a família no principal palco da vida privada, a área doméstica começa a se opor a área pública e, sabemos, as mulheres são incentivadas a permanecerem em casa, cuidando do marido e dos filhos.

"Na história da família ocidental o poder paterno sempre acompanhou a autoridade absoluta e despótica do homem sobre filhos e esposa" (LINS 1997, p. 92).

Logo, nesta família moderna, constituída de pai, mãe e filhos, o modelo de funcionamento ideal é quando a mãe zela pelo bem estar dos filhos e do marido, o pai é aquele que sustenta a família, não permitindo que nada material lhes falte e os filhos existem para serem protegidos e amados. "Nessa nova família, (....), o homem se afasta de casa para trabalhar nas fábricas e escritórios e a mulher se fecha no espaço privado do lar, cuidando dos filhos. Para que este sistema funcione bem, é inaugurado o amor romântico" (LINS 1997, p. 110).

Portanto, o sentimento de família não pode ser referendado à uma época anterior ao século XVII e, dentro da concepção moderna de família, antes do século XVIII, onde é consolidada, até mesmo devido a uma relação de interdependência com a valorização da criança, o papel de mãe tal como o conhecemos.

Em nosso trabalho, observamos a idéia da existência de uma grande responsabilidade feminina a partir do momento que se constitui uma família: 
(....)... Mas eu acho que uma mulher pra ser mulher não basta só ter um filho, casar, tem que ter responsabilidade.(....) né, que não adianta eu ter um filho, eu ser casada, e daí? Né.. não ter minha responsabilidade, eu acho que ser mulher tem que ss- ser mulher e ter responsabilidade, né, é isso que eu acho.

(....)...Hoje? (....) A minha filha, né.(...) Porque depois que eu tive ela, a gente tem um sentido, né, nasce- a gente aprende depois que a gente casa, tem filho, a gente começa a aprender que não é mais é...é, clubinho, né, boate, essas coisas, tem coisas mais importantes, não é? Prá mim é isso. ...E...a...mulher com a - pra falar - ela tem uma responsabilidade muito grande a partir do filho, né, em tudo, né, na casa, no filho, eu acho que é isso.

Esta entrevistada, quando fala que não basta casar e ter filho, que é preciso ter responsabilidade, parece falar, diretamente, das funções da mulher na família, da mudança que há entre uma mulher solteira e sem filhos e uma mulher que tem casa, marido e filhos. No entanto, fala mais que isso, que a mulher, para ser verdadeiramente uma mulher, não basta constituir a família e sim responsabilizar-se por ela, cumprir o papel feminino, no que se refere aos zêlos com marido, casa e filhos. Ou seja, a idéia de que a identidade feminina está necessariamente vinculada ao desempenho responsável das tarefas de esposa e mãe.

Contudo, uma vez sem companheiro, a assunção total da responsabilidade em termos emocionais, morais e financeiros, surge como sendo um encargo muito pesado. 
Ademais, casar possui também um sentido simbólico, uma realização individual no plano subjetivo: “(....) somente a partir dessa união a mulher obtém o espaço material e simbólico para viver a condição inerente ao sexo feminino" (BRIOSCHI \& TRIGO 1989, p. 53).

(....) ...eu num.. faria a besteira de ser mãe novamente, né, então assim, mãe solteira, não, porque é muito complicado. (....) ...ela tem mais responsabilidade, que quando ela é... ela é sózinha, que ela não tem (filhos), ela é solteira...! $E$ a... mulher com a - pra falar - ela tem uma responsabilidade muito grande a partir do filho, né, em tudo, né, na casa, no filho, eu acho que é isso... Olha, na verdade, eu falaria uma coisa que... eu cuido da minha filha sozinha. O pai dela não me ajuda.

Logo, a besteira não é ser mãe e sim, ser mãe sem possuir um companheiro, ser mãe solteira. É curioso perceber que esta designação "mãe solteira" é bastante difundida e utilizada por todos nós. Caberia a pergunta sobre que tipo de vinculação existe entre uma palavra e outra, mãe e solteira. Não seria mais coerente dizer mulher solteira ou filho sem pai? Afinal, a solteirice da mãe, teoricamente, não afeta diretamente sua relação com o filho, não aponta menores ou maiores condições em ser mãe, aponta sim seu estado civil, no caso, de solteira, e, por outro lado, a maternidade da solteira não afetaria, ainda teoricamente, a relação desta com um par. O filho sem pai, não necessariamente é filho de mãe solteira. No entanto, a "mãe solteira" é o oposto da "mãe de família", ou seja, daquela mulher que é 
casada e tem filhos, mesmo que estes não pertençam a esta união, e que, principalmente, se dedica somente à família. Se, na primeira expressão há algo de indigno, na segunda há muita dignidade e respeitabilidade. Fato é que existe, na prática, como estamos vendo, uma diferença: a mãe sózinha sofre dificuldades para ser mãe, dificuldades tanto de ordem financeira como de ordem moral e portanto, social.

A ausência de um companheiro, ou ainda mais, de um pai para os filhos traduz-se portanto, em uma tarefa mais difícil e árdua que consiste em se responsabilizar sozinha pelo filho e, podemos inferir, existir também o ônus de não possuir o que se entende por família.

Há temores e dificuldades na assunção da chefia da família, chefia esta entendida segundo artigo de CARVALHO (1998), que afirma que este conceito não deveria compreender apenas os casos onde a mulher é chefe pela ausência do companheiro, mas também quando é responsável economicamente pelo grupo domiciliar.

Realmente, há uma crescente expansão do fenômeno chefia feminina e este está associado a diferentes causas históricas, econômicas e sociais, mas que é (....) "em grande parte associada ao potencial que as populações vivendo nestas circunstâncias têm de estarem submetidas às situações de maior pobreza e vulnerabilidade econômica" ( CARVALHO, 1998 p. 84). 
É portanto, reiteradas vezes, reconhecida a grande dificuldade em criar os filhos e vencer os obstáculos cotidianos sem a ajuda de um cônjuge: (....) As vezes se separam do marido, mas mesmo assim tava lá lutando.

A ausência do companheiro, pode significar um tal grau de pressão, que traz o temor de uma possível desestruturação de personalidade, uma perda do sentido da vida:

(....) Tem muitas mães que vivem separadas dos maridos, né. Muitas faz... sei lá se joga do prédio, faz loucuras...

BRIOSHI E TRIGO (1989), realizam profícua reflexão sobre o conceito de família. Em seu trabalho, com base em pesquisa empírica, mostram como o casamento, entendido como aliança formalizada ou não, é de capital importância na vida das moças, e que estas, representam esta união como o passo necessário para o ingresso na vida adulta, para o desenvolvimento pessoal e para a legítima participação na sociedade. Mostram também, o casamento sendo visto como uma via, sob certo aspecto, para sair do lugar de dominada e ocupar o lugar de dominante, ou seja, sair da posição de filha para ocupar o lugar de dona de casa, evidentemente, um sonho de dominação restrito ao âmbito privado e que desconsidera a influência do patriarcado. Em entrevistas realizadas com mulheres pobres, pertencentes à classe trabalhadora, aparece uma representação do casamento como 
solução para a precariedade material em que vivem. Essa percepção tornase constatação de possível e fácil aplicação no caso das entrevistadas do presente trabalho:

(....) ...porque eu moro com a minha sogra, assim, eu ganho pouco, né, e se não fosse ela, não sei como ia estar hoje, porque eu não tenho meu marido, né. (....)

(....) ... porque a gente sempre precisa dos pais, né...

O sentimento que provoca a falta de um companheiro, da maneira como é narrado, parece denunciar uma insegurança em assumir o modelo de família constituído, mãe e filho, como sendo um modelo real e viável. Esta sensação de inadequação parece estar, em alguns momentos, apoiada também na crença de que não conseguiram evitar os maus passos da vida pelo fato de não terem dado ouvidos às recomendações paternas, agindo assim, de forma diferente das jovens de antigamente e estragando completamente um futuro de, aparentemente, mais serenidade.

(....) tanto que eu sou mãe solteira e foi bem complicado, tipo assim, se eu fosse voltar agora atrás, se eu pudesse retornar, eu num.. faria a besteira de ser mãe novamente, né, então assim, mãe solteira, não, porque é muito complicado.

(....) porque elas pensavam, né, primeiro se casavam, né ouviam conselhos das mães, dos pais, né e hoje não, hoje em dia as pessoas não escutam mais, mãe, pai (....) 
"O tipo moderno de família e casamento entrou em crise porque foram abalados seus fundamentos: a divisão sexual do trabalho e a dicotomia entre o público e o privado atribuída segundo gênero" (VAITSMAN 1994, p. 35).

Como fica a divisão sexual do trabalho se a parte masculina não está presente e como lidar, em termos morais, afetivos e financeiros, com uma família que se considera incompleta devido a ausência, real ou não, da figura masculina.

Não obstante a crise desta forma moderna de família, o desejo de constituí-la, dentro dos mesmos moldes, parece permanecer.

Para algumas, nem todas são... pra algumas é importante ter um filho, ter uma família, um lar, sabe? Ter uma família. é.. pra umas são, tem outras que não faz questão de... ter uma....uma família, e... né, isso não é importante na vida delas.

Revelado de várias maneiras, fica patente a grande importância delegada à família, em seu modelo burguês, que desperta tantas cobiças e tantas promessas, entre elas valores que podem diferenciar positiva ou negativamente umas mulheres de outras. 


\section{EDUCAÇÃO}

As falas que analisaremos aqui provém da questão onde se indaga sobre as semelhanças e/ou diferenças entre ser mãe hoje em dia e antigamente. Desta forma, muito das narrativas que encontraremos aqui coincidirão com as narrativas da categoria "Transformação ou manutenção?". No entanto, achamos importante dar um tratamento isolado ao tema educação por considerarmos ser tema crucial quando falamos de ser mãe.

A questão cinco diz: "Você acha que ser mãe hoje em dia é igual a ser mãe antigamente?" Um dos temas centrais que esta questão suscita para todas as entrevistadas é o da educação.

Em suas falas, podemos observar que o que estão chamando de educação diz respeito a educação dada pela mãe ao seu filho, na criação destes, e o teor desta educação se refere bastante ao assunto da disciplina, da tarefa de colocar limites, obter obediência e consequentemente, boa educação.

Em seus trabalho, ÀRIES (1978), escreve que há um momento na Idade Média em que a educação das crianças era garantida pelos adultos de seu entorno, e que, a partir dos sete anos, ela passava a viver com outra família que não a sua. Posteriormente, ou seja, passado a Idade Média, a escola deixa de ser reservada unicamente aos clérigos e se torna para todos um instrumento de passagem da infância para a idade adulta. Essa 
mudança correspondeu, segundo o autor, a uma necessidade de rigor moral por parte dos educadores e uma preocupação de isolar a juventude do mundo dos adultos, considerado corrompido. "Mas ela correspondeu também a uma preocupação dos pais de vigiar seus filhos mais de perto, de ficar mais perto deles e de não abandoná-los mais, mesmo temporariamente, aos cuidados de uma outra família" (ARIĖS 1978, p. 232). O que, ainda segundo o autor, exprime um início de aproximação do sentimento de família ao sentimento de infância, outrora separados.

Em fins do século XVII, começou a surgir toda uma preocupação moral voltada para o infante. "É entre os moralistas e os educadores do século XVII que vemos formar-se este outro sentimento da infância (....) e que inspirou toda a educação até o século XX" (ARIĖS 1978, p. 162). O primeiro sentimento de infância é caracterizado pela 'paparicação' e surgiu no meio familiar, o segundo sentimento de infância proveio de fonte exterior à família e preocupava-se com a disciplina e a racionalidade dos costumes.

O sentimento de 'paparicação', surge no seio familiar e exprime o desejo de mimar e prover de carinhos a criança pequena.

O segundo, proveio de fonte exterior à família: eclesiásticos, moralistas e pedagogos não consideravam crianças como criaturas encantadoras e sim, criaturas de Deus que necessitavam ao mesmo tempo de preservação e disciplina. Esse sentimento passou, posteriormente, a pertencer também à vida familiar. 
(....) Ela... eu acho que assim trabalhar, batalhar, pra educar os filhos, entendeu?

(....) ...minha mãe não trabalhava, ficava comigo e com a minha irmã, né, então nós éramos muito, assim apegadas, né? Minha mãe olhava e a gente não fazia mais as coisas, hoje não, meu filho, as vezes, eu tenho que dar uma palmauma palmada nele, porque não vai, né. Não obedece.

A interpretação de que existe uma força rebelde a ser domada, parece estar subjacente a punição física.

Com mais ênfase a partir do século XVIII, a maternidade adquire novo sentido. O trabalho materno não se restringia aos cuidados físicos com a criança, à mãe cabia também a educação e parte da formação intelectual. “Tomou-se consciência de que a mãe não tem apenas uma função 'animal', competindo-Ihe também o dever de formar um bom cristão, um bom cidadão, um homem, enfim, que encontre o melhor lugar possível no seio da sociedade. O que é novo é o fato de ser ela considerada a mais indicada para assumir esses encargos. É a 'natureza', diz-se, que the atribui tais deveres" (BADINTER 1985, p. 237.).

Ou seja, a educação tem um sentido mais amplo do que a instrução, é também a transmissão de valores morais. "O século XIX parece redescobrir, depois de Fénelon e Rousseau, que essa tarefa importante cabe à mãe, pois só é bom educador aquele, ou melhor, aquela que conhece perfeitamente o 'terreno' das operações” (BADINTER 1985, p. 256). 
A pergunta feita, por sua vez, estimula de forma mais deliberada a comparação entre tempo anterior, que as entrevistadas localizam como sendo o tempo de suas mães e avós, e o tempo atual, onde localizam a si mesmas e suas pares contemporâneas:

Ah, o antigamente, pelo que a minha avó fala que... as crianças não é como são hoje, né?

O ponto comum encontrado nestas respostas, no que tange à comparação feita entre antigamente e hoje em dia, é que hoje ocorre uma maior permissividade da mãe na criação de seus filhos e, antes, as mães eram mais rigorosas e conseguiam impor respeito e disciplina às crianças.

Mas antigamente eu acho que era mais rígido, acho que era bem diferente. Hoje em dia não, a mãe acho que tolera tudo..

As mães de outrora conseguiam corrigir seus filhos.

Uma mãe ela tinha...ela tinha que corrigir aquele filho de todo jeito, hoje em dia a mãe num tá conseguindo fazer isso. É difícil, tem umas que até deixa de....mão

Minha mãe olhava e a gente não fazia mais as coisas, hoje não, meu filho, as vezes, eu tenho que dar uma palma- uma palmada nele, porque não vai, né. Não obedece.

Estas mães encontram diferenças entre elas e suas mães, na realização da tarefa de educar seus filhos, dificuldade que, consideram, 
reside na relação entre elas e seus filhos. Diferente das mães do passado, elas se consideram menos capazes de discipliná-los e estes, por sua vez, tornam-se mais rebeldes. Isso parece gerar um ciclo vicioso, esta sensação de incapacidade parece conter uma ponta de culpa e por isso a tolerância maior, o que parece se relacionar também a uma queixa pelo fato de ter que trabalhar fora e, consequentemente, ter menos tempo junto ao filho.

Por outro lado, esta maior tolerância também é vista, como algo positivo, algo inovador.

(....) As de antigamente, elas se preocupavam mais, né, trancava mais, prendia mais as crianças hoje em dia...tá liberal (riso), né... (pausa) Não é igual a antigamente.

(....) É...tinha papo que você não conversava com sua mãe, era tudo desconfiança, né. Hoje não, hoje eu - eu até tenho esse problema com a minha filha que eu não sei quando parar, as vezes ela fala: "não, mãe, eu vou, eu vou, eu vou" então eu não sei se eu brigo, que qui eu faço, coisa que minha mãe já iria ali, e bateria em mim ou, né, daria um beliscão, coisa que eu tento hoje, sabe, mudar isso. Então educação hoje é totalmente diferente de antigamente, né. Minha mãe mesmo fala, hoje ela mudou (....) Hoje, é.. depois de 8 anos, né, do ultimo filho, ela teve, né, uma menina. E.. a nossa educação é totalmente diferente, nossa ela é super liberal; minha irmãzinha ela conversa com todo mundo, ela não é presa, sabe? Quando a criança é ....tem personalidade., tá? $E$ antigamente, não, não deixavam a gente ter personalidade, por isso que eu falo, quando vêm a experiência aí a gente fica, sabe, bate na cabeça, é difícil entender as coisas, tem que quebrar a cara, tem tudo isto que a educação hoje em dia é bem melhor. Você pode conversar com psicólogos, pode levar seu filho vamos dizer, se tem uma separação cê pode levar no psicólogo, pode passar para alguém para te ajudar, para te orientar. 
Pode haver também, embutido aí, um desejo implícito de mudança no que se refere à forma de educar e disciplinar os filhos, com uma flexibilidade maior, uma vez que outrora, os castigos eram comuns como forma de educação. Como vimos anteriormente, desde o início do sentimento de infância, descrito por ARIÈS (1978), para combater o insurgimento de uma criança mimada e estimular o bem educar, recorria-se ao castigo. "E tudo indica que tais castigos eram as tradicionais palmadas" (DEL PRIORE 1993, p. 317)

Enfim, a formação do filho, entendendo aqui por formação as primeiras instruções, a transmissão de valores caros ao grupo de pertencimento, de aspectos relativos a higiene e bons costumes, e até mesmo a algo da educação institucionalizada em seus primeiros passos, são responsabilidades da mãe, mesmo que não haja plena consciência disto, é parte de seu dever e poder, e nela recai toda a cobrança quando algo não sai a contento. 


\section{RESPONSABILIDADE E TRABALHO}

Quando a necessidade da busca pela subsistência entra em cena, a mãe traz um sentimento de grande sobrecarga na conjunção desta necessidade e a lida diária com seu filho.

Esta sobrecarga, às vezes se traduz, em uma cautela com relação a ter filhos, colocando questões de ordem financeira como um balisador da quantidade de filhos a se ter:

(....) Agora no máximo que a gente pode ter é dois. Mesmo assim com dificuldades. $E$ tem muitas que tem muita dificuldade financeira.

Em sua pesquisa, BRIOSHI \& TRIGO (1989) trabalharam com quatro grupos de mulheres pertencentes a duas classes sociais distintas (esposas e filhas de empresários e de trabalhadores) e duas gerações (mães e filhas). Nesta pesquisa chegam a vários pontos de interesse ao presente estudo, entre eles, verificaram que a partir do objetivo de melhorar o status quo, as jovens pertencentes à classe trabalhadora pretendem ter poucos filhos.

Entre as jovens de classe trabalhadora, a grande preocupação gira em torno de uma melhoria das condições de vida e de uso das estratégias possíveis para que este objetivo seja alcançado. É assim que ao lado das críticas que fazem às mães por terem tido muitos filhos, têm como projeto de 
vida controlar a natalidade. O adiamento do casamento é um dos recursos a serem utilizados para a diminuição da fecundidade (BRIOSCHI \& TRIGO 1989, p. 74).

Esta cautela as vezes pode aparecer como um impeditivo para ter filhos:

(....) Eu acho que tem que pensar muito, né para depois ter um filho. Se ter condições, tudo bem, né, mas se não tiver... não dá pra ter a- por enquanto, né?

A administração simultânea dos cuidados com o filho e do compromisso em obter o sustento, revela uma ansiedade no cumprimento solitário de ambas as tarefas tornando preemente a necessidade de outrem que as auxilie. Interessante notar que as mães encontram, ou procuram esta ajuda, na maioria das vezes, na solidariedade de outra mulher (a própria mãe, a tia da criança, a sogra):

(....) Ah, sei lá, eu acho que é muito difícil, né pra... porque eu moro com minha sogra, assim, eu ganho pouco, né, e se não fosse ela, não sei como ia estar hoje, porque eu não tenho meu marido, né (....)

A liberdade substituída por grande responsabilidade ao ter filho solteira, responsabilidade esta que necessita da ajuda do outro, feminino, que se dá através de uma troca implícita: 
(...) Pra mim era bem diferente, porque eu tinha a minha liberdade. Trabalhava pra mim. Agora eu tenho que trabalhar para mim e pra sustentar minha filha e ajudar minha mãe, né, por ser mãe solteira.

É possível inferir que ao mesmo tempo que há a ajuda no cuidado com a criança há, em contrapartida, uma contribuição na economia doméstica. O que denota um dia a dia preenchido pela árdua tarefa de garantir a criação dos filhos e a sobrevivência do grupo familiar.

Com relação a este ponto, recorreremos a CARVALHO (1998) que defende, em seu trabalho, uma política pública voltada para famílias chefiadas por mulheres, uma vez que considera estas famílias mais vulneráveis economicamente por vários fatores, dentre eles o fato desta família muitas vezes ser composta, em sua maioria, por uma população infantil que não produz rendimentos.

(....) em sociedades como a brasileira somente a mulher assume as funções domésticas de um grupo familiar. Isto dificulta a conjugação entre trabalho remunerado, cuidado com os filhos e atividades domésticas. (....) Às vezes não tem outra escolha a não ser vincular-se a trabalhos mais mal remunerados (....) Além disso a mulher provedora concorre em um mercado de trabalho que opera e recruta tendo a mulher sobre a ótica de trabalhadora secundária e de 
rendimentos complementares em um domicílio (CARVALHO 1998, p. 85).

Em apenas um caso foi referendada a participação da instituição, creche, no cuidado com a criança no período de trabalho da mãe.

(....) Aí tem que deixar na creche, né, para outras pessoas cuidarem.

Muito embora, todas as mães entrevistadas tenham seus filhos na creche.

Em alguns destes relatos parece existir a fantasia de que a presença de um companheiro ou a ajuda do pai da criança, as deixaria em uma situação mais confortável não só em termos financeiros como também em termos emocionais.

A percepção do mundo atual é de que este é mais duro do que no passado, o que parece agravar a ansiedade no que se refere ao desejo de dar boas condições de vida para o filho:

(....) o padrão de vida também não ajuda. E o mundo também... esta pior, né, então cê tem que caminhar direitinho, passo a passo, para tentar dar o melhor para o seu filho.

(....) porque tive uma vida difícil, trabalhei desde os 16 anos...(...) 
O fato da mulher ter que trabalhar fora e deste modo possuir menos tempo junto ao seu filho também é visto como decorrente das dificuldades do mundo atual e pode gerar a fantasia de que tal situação traz uma conseqüente diminuição na afetividade das relações.

(....) Ah, porque antigamente, as mães não, não trabalhavam, né, então tinham mais atenção com seus filhos, não é? $E$ hoje em dia não, nós temos que trabalhar para ajudar, então é diferente...A gente fica pouco tempo com os filhos da gente. Só a tarde, né, no fim da tarde aí a gente vai dormir, depois só no fim de semana.(....)

(....) Eu acho que antigamente, que nem, no meu tempo, minha mãe não trabalhava, ficava comigo e com a minha irmã, né, então nós éramos muito, assim apegadas, né?

O trabalho que diz respeito especificamente aos cuidados com o filho trazem, o testemunho de um aspecto árduo, muito embora este é quase sempre justificado por um sentimento gratificante.

(....) Apesar dos trabalhinhos que dá, né mas é.. eu acho que é muito bom.

(....) eu estou adorando (riso), apesar de tudo, né, porque o meu filho é muito....de vez em quando tem que levar no médico, quase sempre, né, ele está sempre doente, quase, mas ..está em primeiro lugar pra mim .

(....) tem hora de trabalho e hora de alegrias também. Tem hora difícil que é acordar à noite, sempre tem isso não é, mas também tem hora que é muito boa. Eles brincam, eles dão risadinha, falam coisas. Então, s-só isso. 
Mas novamente a cautela emerge e vem a advertência de que a tarefa de cuidar de uma criança pode, algumas vezes, tornar-se uma carga excessiva e requer intensa dedicação.

(....) Ter responsabilidade com o filho, ter cuidado, ficar preocupada, sabe, se está bem, to-se esta comendo direito, como é que tá, quando fica doente, ficam-algumas mães ficam bem desesperada, entendeu?

Estamos vendo que a maternidade e as implicações desta com a vida que as mães possuem, são vistas como uma grande responsabilidade e esta pode trazer desespero ou pode trazer amadurecimento. Podemos suspeitar que este amadurecimento a que as mães se referem diz respeito a uma maior experiência e prudência com a vida, após vivenciar as dificuldades decorrentes de ter filho e trabalhar para o sustentar.

A partir dela ser mãe. Aí eu acho que a responsabilidade é bem maior e ela se amadurece mais.

Ah, eu acho que.. ser mãe tem que... responsabilidade. Tem que... estar preparada para ser mãe.

De todas as formas, o sentimento de sobrecarga e a advertência sobre este, é veemente e surge associado a uma grande responsabilidade provinda destes dois gigantescos compromissos, o de trabalhar para ganhar 
o sustento e o de cuidar do filho, que são em última instância o mesmo, o compromisso de manter a vida.

(....) ...é difícil, né...assim, ah, não sei porque tudo é difícil, né?... ah, que nem, assim, tem vez que o serviço da gente é corrido, até buscar ele, tem dia que não dá pra gente buscar, aí a gente pede pra alguma pessoa, pra tia dele assim, não pode, não pode vim buscar, aí a gente tem que fazer, que é a maior correria, né... que nem outro dia eu falei pra tia dele buscar e não dava, aí eu vim quatro horas, depois levei ele na minha casa pra a mulher cuidar, aí depois vim pro serviço de novo pra terminar de passar roupa, isso é difícil, né (....)

(....) ...Eu acho que o que eu falaria pra's pessoas da minha idade, era isso, né, e ter-eu acho que... chegasse um ponto assim de cuidar para não ter filho, né, cuidar muito bem pra não ter filho, nessa idade, porque a gente se acaba muito também, que é muita responsabilidade pra você... pôr na sua cabeça... que hoje acho que... na minha idade, acho que jamais tá sendo alguém assim que... pára, a mãe também pensa pra não ter filhos, porque é um pouquinho de trabalho, né. Aliás acho que não é bem pouquinho, é um trabalho dobrado. Acho que é isso........)

Se há, por um lado, certo orgulho no fato de vencer as dificuldades diárias e cuidar dos filhos, parece haver também, embutida nas palavras de cautela, uma certa decepção com o que a vida lhes reservou.

Por outro lado, vimos anteriormente, que existe o desejo de constituir uma família dentro dos moldes burgueses, podemos pensar que casar-se significa uma melhora de vida em termos materiais. "Há uma aplicação ao campo econômico da magia que envolve o ato de casar (....) O sonho era 
trabalhar para as próprias famílias, tomar conta da própria casa" (BRIOSCHI \& TRIGO 1989, p. 54-55).

Contudo, trabalhar fora significaria, para esta população, muito mais uma busca de rendimentos do que uma questão de realização pessoal em termos profissionais. Ou seja trabalhar fora pode se revelar algo antagônico ao sonho de melhorar de vida, dentro da idéia de, apenas, cuidar de sua própria casa e família. A realidade mostrou-se outra, as dificuldades impõem a necessidade de um trabalho para completar ou, simplesmente, constituir um orçamento. $\mathrm{O}$ trabalho fora, as tarefas domésticas e a lida com o filho torna-se assim, uma grande sobrecarga. 


\section{UM MAU MOMENTO}

Foi pedido às entrevistadas o relato de uma situação que considerassem ruim, desagradável, de dificuldade, no convívio com o filho. O pedido para que contasse uma situação ruim junto ao filho intentava, a princípio, estimular relatos de atrito entre mãe e filho(a), exemplos de experiências concretas que trouxessem situações de conflito.

Contudo, estas narrativas se centraram em circunstâncias ligadas a doenças e acidentes ocorridos com o filho (a). De uma parte, isso nos faz pensar em algo na ordem daquilo que já discutimos na categoria "mãe boa, mãe má", sobre projeção. Ou seja, da necessidade que há em colocar no outro, e aqui o outro seria o acaso ou o destino, todo e qualquer sentimento maligno, ou melhor, visto como maligno, principalmente quando há o envolvimento da relação com seu filho, devido a várias questões de ordem pessoal até social. De outra parte, se pensarmos que o contexto de entrevista era a creche, podemos pensar em uma hipótese que traz um aspecto de persecutoriedade pela qual essa mãe pode estar passando. Se trata da percepção de certo perigo ou ameaça quando é solicitada uma entrevista com uma mãe, na creche. Esta sensação de ameaça pode girar em torno do merecimento ou não daquela vaga para seu filho, quanto mais se o assunto da conversa gira em torno da relação mãe - filho.

Pedir-lhe a sua concepção de maternidade, assim como indagar-lhe uma situação ruim vivida junto ao filho, poderia estar provocando 
insegurança. A entrevista, contudo, mobilizou os discursos em torno de assuntos ligados a doenças e acidentes para falar de um momento ruim. De todos os modos, falar de cansaço, de intolerâncias, de exasperação, enfim, de sentimentos taxados de negativos, é comum em circunstância de maior intimidade, encontro de confidências ou desabafos, mesmo porque, sabemos, não soa correto mães falarem da existência desses sentimentos com relação aos filhos, em situações mundanas, que dizer em uma situação de entrevista.

Por outro lado, entendemos que as situações ruins que foram escolhidas possuem a força da vida e da morte, todas as mães trouxeram relatos sobre acidentes que machucaram ou colocaram a criança em perigo, ou relatos sobre hospitalizações e doenças.

$E$, quando se trata de doença, esta é vivenciada como um momento de dor, tensão e de "stress" físico ou emocional.

Ah, a chata, difícil é quando ele tá doente, que cê tem que ficar no hospital com ele, que ele fica "ai mãe não quero ficar aqui, quero sair daqui” isso prá mim é... é muito chato, dói em mim né, prá mim é chata essa situação viver com isso dói muito em mim né, porque criança quando tá doente é difícil prá qualquer mãe né, acho que é isso uma situação difícil.

(ri) Sei lá... eu não tenho um difícil assim sabe, sempre foi razoável, não teve um... ai... há uns 15 dias atrás, ela ficou doente né, teve uma catapora e... não deixava eu dormir e nem ela dormia (ri) foi um pouco difícil, uns dias... que ela ficou sem dormir e nem deixava eu dormir, mas passou (ri). 
O medo de uma eventual perda concreta pode ser gerado pela sensação de que o filho está definhando quando é o caso de uma doença mais constante.

Ah, quando ele fica muito doente né, porque ele sempre ficava doente, agora que tá melhorando, por causa desse problema do nariz né, mas com os remédios já tá ajudando bastante, que ele vivia doente, magrinho, magrinho, magrinho, comia nada, agora que ele tá melhorando (....)

A possibilidade do advento de uma doença mais grave também acentua o temor de uma perda concreta, temor tão terrificante, que uma vez passado, o melhor é degustar o alívio, e se porventura houvesse indignação, esquecer, e seguir em frente.

Difícil...ai, dor de ouvido, que eu ia em médico e médico e saia na conclusão, uma vez ele ficou internado por causa de dor de ouvido e acharam que era uma doença... não sei muito bem o nome né, mas que...deixa a criança para- paralítica né, ai... na hora que a médica falou, tudo bem, normal, quando fui ter a situação, da idéia da... o que a doença causa, ai eu fiquei des... desesperada, aí eu fiquei com ele um dia, ele ficou um dia internado, isolado, pensando que era essa doença, no fim não era, era uma dor de ouvido, e no fim eu fiquei assustada à toa, e os médicos né, ma... prá mim foi o... a melhor coisa assim, um momento meio assim... comovente assim, meio triste, e vamos, vamos seguir em frente.

Ah, quando teve pneumonia (ri) acho que foi a..., acho única também, foi a pior situação que eu já vivi com ele, foi quando teve pneumonia. 
A responsabilidade na tomada de decisão em assuntos de doença é vivida com maior peso, principalmente na ausência do pai da criança.

A primeira vez que ele ficou internado, graças a Deus a primeira e única, até agora né, eu tava só, o pai dele viajou né, que eu... o pai- o pai do meu marido adoeceu, então ele teve que viajar e... exatamente na semana que ele viajou, meu filho adoeceu, adoeceu teve febre, levei pro médico, passei aquela situação chata, e prá, ficar, de repente faz vários exames, aí, decidir, vai ficar internado e transferir de um hospital prá outro, sozinha... foi muito difícil, é a mais difícil até agora né.

Quando forçada a uma separação em um momento tão precoce, a dificuldade parece residir no ato de deixá-lo no hospital, e não em sabê-lo precisando de cuidados especiais.

Foi difícil, foi deixar ele no hospital né, quando ele nasceu, aí nasceu com problema da tirícia, aí teve que ficar no hospital e eu fui embora...da tirícia, que nasce bem amarelinho...aí ele ficou no hospital, aí eu fiquei, aí foi chato...

É difícil deixá-lo sem a sua presença, ou deixá-lo com sua ausência, mas é difícil para ela, mãe, revelado no fragmento (....)aí eu fiquei (....). É possível que considerasse a sua presença algo que auxiliasse a melhoria do filho ou pode existir, na fantasia da mãe, a idéia de que a criança poderia interpretar este ato como um abandono.

Acrescentaremos aqui os depoimentos que falam de separação e de proximidade, por considerarmos complementar aos relatos de doenças e 
acidentes. Contudo, vale dizer, as mães que trouxeram estes depoimentos falaram de doença ou acidente, assim como as outras, quando indagadas sobre um momento ruim junto ao filho (a).

Além da possibilidade, bastante viável, de ocorrer a fantasia de que a distância do filho pode causar o esquecimento e, consequentemente, a diminuição do amor que este sente pela mãe, pode haver também a idéia de que o filho não terá como verdadeiro (nem sequer a notícia) da existência do amor materno. No imaginário da mãe, isto pode significar a perda do universo de mãe e tudo que ele representa. Se o amor do filho mingua por ele achar que sua mãe não mais o ama, está abalado um dos sustentáculos da relação mãe filho como é hoje.

Podemos observar a seguir, o contraponto disto, que seria o convívio, a proximidade, com o filho (a), mesmo que sazonal, que é o que pode fornecer a oportunidade de manutenção deste amor. As mulheres que proferiram as falas a seguir, viveram ou vivem, a situação de ter o filho(a) morando longe de si.

A situação?... Ai, (ri) qual que eu posso dizer? Ai, ele tá aqui comigo, e... gosto muito, deixa eu ver qual a situação... Ah, quando eu chego em casa, assim as vezes eu chego lá, ele diz assim 'ah, a mãe chegou, a mãe vai me levar pro shopping' aí eu levo ele pro shopping, ele se diverte, essa é a parte, que ele não desgruda de mim, essa é a mais maravilhosa (fala rindo) a etapa mais maravilhosa, deixa eu ver...ah, é que eu não convivo muito com ele, eu não posso dar um assim ...é isso? 
Hum... hum isso é tão difícil responder (ri) bom, apesar né, que o outro seria mais difícil, mas essa... né, acho que... o mais legal é o que eu tô vivendo agora né, que eu tô com ele... mesmo, e ele conversa todos os dias comigo, que conversa, nossa, que ele fala super bem is... acho que esse é o mais legal que eu tô sin... que eu sinto né, é só isso (ri)

Que foi chata foi difícil? Foi quando ela tinha seis meses eu tive que me separar dela deixei ela com a minha mãe e eu vim prá cá, deixei ela na Bahia, no norte, com a minha mãe e, eu vim prá cá, fiquei três meses sem ela, foi uma situação bem difícil foi três meses de ch... a nível de choro e aí que com-assim, com a... os três meses que eu, que eu fui buscar ela, nossa ai foi bom, esse foi e... o mais difícil que eu tive de lá prá cá foi tudo bem, só isso.

A possibilidade da doença afetar a cognição da criança e desta deixar de identificá-la enquanto mãe provoca bastante angústia.

Ah, o dia em que ela ficou internada né, o dia que ela ficou internada, foi o... a pior coisa, porque a gente ficou dois, duas noites no hospital com ela no soro, é, ela num... não se lembrava não, se era, não sabia que era a gente, o torno do tombo que ela levou, isso foi o pior momento que a gente passou...

Todos os relatos sobre acidentes diziam respeito a situações acidentalmente provocadas pela mãe. Este fato promove uma intensa culpa, que nas narrativas, aparecem como uma preocupação em, imediatamente, apresentar justificativas, ou alusões, à sua falta de experiência enquanto mãe. 
Ai, tadinho, eu lembro num dia que eu fui dar banho nele né, a primeira vez que eu fui dar banho no P., tadinho do meu filho (ri) eu tava de resguardo nesse dia, minha mãe não tinha chegado ainda prá ficar comigo né, e nem minha sogra, e eu fui dar banho no Pablo e virei ele assim de cabecinha prá baixo né, e ele sufocou tadinho né, na água sabe, ficou sufocado, o rostinho, foi nesse dia que eu fiquei apavorada sabe, porque marinheira de primeira viajem né, $P$. ficou todo roxo, nossa, esse dia foi... super... chato prá mim né (ri) fiquei aflita né(....)

Foi quando ele tinha 18 dias, ele, é... eu dei mamadeira prá ele, e coloquei ele deitado, no... no berço né, só que ele se... se mexeu assim um pouco e ficou co... com o rosto assim prá cima, então ele...ele aspirou o leite prá dentro, então a gente saiu correndo pro hospital, saiu leite pelo nariz dele, pela boca, quase que ele morreu... esse foi o pior da minha vida ...

Em um dos casos, a possibilidade de seqüelas parece trazer a fantasia de que futuramente este filho(a) poderá julgá-la negligente ou, até mesmo, perceber o ocorrido como uma falta de afeto derivada da desatenção.

Chato? Bom o momento chato foi quando ela, ela tinha um furunquinho e eu não sabia né, eee... ai ela... pediram prá eu fazer uma compressa nela né (criança chama a mãe)... pediram prá fazer uma, uma compressa nela, e...ensinaram como que era tal, que era com farinha, tipo uma gominha né, aí eu..., eu peguei (som de passarinho e criança fala rindo) eu não sabia, sabia que dentro, é tipo assim a massinha por fora parece que tá fria, tá morninha, mas por- por dentro ali tá fervendo então coloquei em cima assim, o médico pediu para colocar! e ai, eu coloquei tudo, quando eu fui abrir a fralda de novo o bumbum tava cheio de bolha, umas bolhas enormes né, ai nossa me deu desespero né, e ela até hoje tem essas marcas, vai ficar essas marquinhas né, até avisava todo mundo para não contar prá ela né, que vai ficar ridícula as marcas, uma coisa assim que eu não gostei que eu sofri 
muito né, porque ficou todo mundo olhando, depois me culparam 'ai como que cê é burra' tal 'como você não foi ver isso?', ah acho que só isso que aconteceu assim de... né, que fiquei preocupada tal, só isso.

WINNICOTT (1983), considera que a palavra preocupação é usada para expressar positivamente algo que em seu aspecto negativo é expresso pela palavra "culpa". Preocupar-se, para ele, implica em "(...) uma maior integração e crescimento e se relaciona de modo positivo com o senso de responsabilidade do indivíduo (....) Preocupação indica o fato do indivíduo se importar, ou valorizar, e tanto sentir como aceitar responsabilidade“ (WINNICOTT 1983, p. 70).

Para a psicanálise, o amor pode coexistir com sentimentos de ódio ou rivalidade e o crescimento se faz quando o indivíduo começa, em sua infância, a integrar o que chama de bons e maus objetos.

Paralelamente aos impulsos destrutivos presentes na mente inconsciente tanto da criança como do adulto, existe um anseio profundo de sacrificar-se, no intuito de auxiliar e de reparar pessoas queridas que em fantasia foram danificadas ou destruídas. Nas profundezas da mente, o anseio intenso de fazer felizes as pessoas está associado a um intenso sentimento de responsabilidade e preocupação por elas, que se manifesta através de simpatia genuína para com outras pessoas e da habilidade de compreende-las, tais como elas 
são e tais como elas se sentem" (KLEIN \& RIVIERE 1975, p.94). 


\section{UM BOM MOMENTO}

Ao pedirmos às mães que contassem um momento bom, agradável, vivido junto ao filho, intencionávamos estimular o surgimento de relatos sobre experiências concretas, exemplos de convívio, no caso, exemplos felizes de convívio.

Todas as mães trazem relatos relacionados às aquisições cognitivas e psicomotoras de seus filhos. Muitas situam o nascimento deste como sendo o momento mais emocionante que viveram, o que pode representar a primeira grande conquista, a conquista da vida. Certamente, isso é facilmente compreensível, ver uma criança nascer, crescer e se desenvolver é sempre gratificante, principalmente quando são seus os cuidados que promovem estes eventos.

As aquisições, além de representarem o sucesso das atenções constantes, representam também o desenvolvimento da independência e a gradativa constituição do sujeito como um sujeito singular. Se levarmos em consideração que as mães relatam estas aquisições quando são indagadas sobre momentos de convívio que Ihes signifiquem bons, podemos pensar

que tais aquisições são interpretadas não apenas como pertencentes à criança, que as vai adquirindo, mas também, de certa forma, entendidas e compartilhadas como vitórias conjuntas, o retorno de um empenho e uma dedicação no crescimento e desenvolvimento do filho. 
Desta forma, o nascimento, que é a primeira grande aquisição do bebê, o ganho da vida, do mundo entorno, é também para a mãe, sob outra perspetiva, o ganho da vida, da vida que gestou e da qual será uma das responsáveis em fomentar e manter, senão a principal responsável.

Eu acho que a situação boa e legal foi o dia que ela nasceu... foi uma das fases mais legal e mais boa que eu tenho passado, foi isso, o dia que ela nasceu...

(....) então foi muito bom, todos os dias são legais né, são umas fases muito legal, mas acho que o mais legal foi o dia que ela nasceu mesmo (fala rindo) que nem, uma coisa muito boa foi essa.

Ai, acho que foi o primeiro instante de vida, acho que foi quando ele nasceu

Prá mim, o momento melhor foi o dia que eu ganhei ela, foi uma situação muito boa, na hora que eu acabei de ganhar ela, que jogaram ela em cima de mim foi, foi muito bom, uma sensação muito boa.

Que foi legal? Ah foi o dia que ela nasceu né, foi muito legal mesmo, no começo ela começou a chorar e, quando ela nasceu, então na hora que ela me entregou ela, eu beijei, abracei, sabe, foi o momento mais feliz que eu tive, muito legal, isso.

Nos últimos dois casos, a referência ao primeiro contato físico parece ser importante para a situação de nascimento, este contato parece realçar a sensação de ganho, sensibilizando a mãe através do experimento e 
concretizando-lhe a chegada do bebê. O nascimento, além de ser o grande ganho, indica também, no caso a seguir, a fantasia de protagonizar um milagre e a reificação da fé em sua crença religiosa.

Ai, foi a partir do momento que ele nasceu né, eu tinha feito o ultra-som né, e. ..deu menina né, eu tava esperando menina né, daí na hora que ele nasceu, aí o médico mostrou prá mim, era um menininho, e eu fique tão emocionada sabe, porque cê vê, Deus não falha na nossa vida né, Deus tinha falado na palavra, eu sou uma serva de Deus né, cê já percebeu que eu sou crente né, então Deus tinha falado na palavra que ia ser menina- é... um menino, um varão valoroso, o filho da promessa né, e nisso na hora que mostrou um menino, eu fiquei tão emocionada assim, confirmação mesmo, a melhor confirmação de Deus né, e era um menino, nossa, acho que era, foi aquele dia prá mim sabe, que eu fiquei tão emocionada, foi nesse dia...

É provável que esta mãe tenha intuído o sexo de seu bebê, quando estava grávida. A tecnologia médica, através da ultra-sonografia, acusou, erroneamente, o sexo feminino. Quando o bebê nasceu e viu-se confirmada a hipótese materna, isto pareceu servir para a sustentação de outras convicções que a mãe possuía, no caso, convicções de ordem religiosa.

Com o nascimento do menino a mãe parece entender que, as falhas humanas, especificamente a falha na previsão do sexo pelo médico, são a confirmação da infalibilidade divina. Deste modo, a vinda de seu bebê é um duplo milagre, o nascimento per si e a mensagem divina que dirigida à ela e que, corroborou sua percepção primeira a propósito do sexo de seu bebê. 
Há a possibilidade de haver também uma identificação com a santa Maria que, na bíblia, foi quem recebeu a mensagem que conceberia um "varão valoroso, filho da promessa".

Tudo aquilo que pode ser interpretado pela mãe como o desenvolvimento de uma capacidade de envolver-se, de interagir com consciência, mesmo que ainda não seja cabível tal configuração, é lembrado como uma vivência preenchida de alegria.

(...pausa...) ai, teve tantas né, mas a mais assim, né? a que eu achei a mais legal... ah.... o momento que eu mais achei legal assim, foi quando ele deu o primeiro sorriso, o primeiro sorriso dele me emocionou muito, ele tinha, acho que uns dois meses, quando ele deu o primeiro sorriso né, acho que foi esse e quando nasceu o primeiro dente dele também.

Ao presenciar a evolução das capacidades e aptidões que muitas vezes, ocorrem velozes, é despertada uma agradável surpresa, principalmente quando há a participação e o testemunho do pai.

(....) ... isso é simples (ri) ah, tem várias situações, mas... deixa eu ver... ah, lembrei, a situação mais legal (ri) a primeira vez que eu vi ele engatinhando, que eu levei ele, daqui da... que ele não tava engatinhando né, então trouxe prá creche, quando cheguei em casa que coloquei ele no chão, ele saiu rapidinho engatinhando, ah eu adorei (ri). Adorei dividir com o pai, também ficou super feliz, acho que foi... até agora, foi a situação mais interessante junto com ele que eu já vivi né...

Ah, quando ele começou a andar, foi muito legal. 
A possível intencionalidade nos gestos do bebê faz emergir um sentido subjacente que, muita vezes pertinente, mostrando uma observação materna perspicaz que sensível ao desenvolvimento da inteligência de seu filho.

Foi num dia que, qui... queria acho que descer, caiu da...da cama, acho que ele chorou, sei lá que aconteceu, ele queria pegar um brinquedo, e o brinquedo já tinha caído, aí ele, acho que ele foi, ver o brinquedo, prá pegar, aí quando eu vi ele já tava... caidinho assim, com as perninhas. dei- é... com as perninhas assim, no chão, já, aí prá mim, assim... foi a melhor coisa que surgiu né, porque é uma sabe... uma felicidade cê ver seu filho esperto né, apesar que cê leva um susto né, porque pode machucar, mas prá mim... foi isso...

Aquisições físicas, juntamente com as aquisições motoras são interpretadas como uma maior capacidade de responsividade da criança, o que também recebe a conotação do desenvolvimento de um maior entendimento do mundo pelo bebê, que se traduz na consciência da existência do outro, portanto, da existência da mãe.

Ah, prá mim quando ele começou se mexer mais né, começou ficar mais espertinho, ter dentinho, prá mim foi isso né, que ele ficou mais espertinho porque por enquanto ele não tá andando né, aí prá mim, melhor assim foi isso, porque ele quando era pequeno não dava nem prá gente s..., aproveitar nada só carrega fica, fica meio serinha, agora não, tá mais sorridente tá uma criança mais ... 
Quando esta responsividade é manifestada através da palavra, a interpretação das mães parece residir na grata percepção de que seu filho a reconhece enquanto mãe e tudo que esta condição representa em termos de dedicação.

(....) depois também o primeiro aniversário, quando ele falou pela primeira vez, ih são tantas e tantas, mas acho que a maior mesmo foi quando ele chamou mamãe .

Ah, de coisa que foi legal, acho que não, viu...(pausa) ah o que tá acontecendo de legal é ela falando né, as palavrinhas assim, "eu te amo", né... essas coisas que criança faz, é descobrindo o mundo né, que ela presta muita atenção nas coisas né, ela grava muito rápido, é... é... então ela é, faz comentários é, mamãe e papai tão trabalhando prá ganhar real sabe, prá comprar roupa, presente prá nós, esses tipo de coisa, isso eu acho legal na criança, e... eu acho, acho que é só isso, ela tá aprendendo a viver né... só isso...

De maneira geral, podemos notar que as aquisições dos bebês reforçam para as mães não apenas o afeto e os cuidados a ele dirigidos. Mas também parece ocorrer uma dialética na relação, onde a mãe se reconhece cada vez mais, enquanto mãe, à medida que identifica as reações do filho como uma interação consigo mesma. 


\section{TRANSFORMAÇÃO OU MANUTENÇÃO?}

A questão cinco diz: "Você acha que ser mãe hoje em dia, é igual a ser mãe antigamente?" Esta indagação estimulou comparações entre dois períodos de tempo. Pelas narrativas, podemos inferir que o tempo entendido como antigamente não se trata de um tempo muito longínqüo, é possível observar que algumas das entrevistadas se refere ao mundo que vivem enquanto mães e o mundo que viveram enquanto filhas, ou ainda a referência de notícias, do passado, provindas de pessoas mais velhas, de seu conhecimento.

A percepção mais comum, trazida a propósito das mães do passado, é que estas dedicavam maiores zelos aos seus filhos, o que, muitas vezes, é entendido como uma maior rigorosidade na criação destes. Como vimos na categoria anterior, "responsabilidade e trabalho", ter menos filhos que suas mães parece ser uma estratégia para melhorar as condições materiais de vida.

Indicações sobre um incremento da demanda de consumo por parte das famílias, que aparece implícita e que remete ao poder aquisitivo, se desdobra em duas faces interrelacionadas: se por um lado esta demanda é vista como sendo menor no passado, por outro lado, hoje há, a custo de muito trabalho e conseqüente remuneração, uma pequena melhora da condição financeira. Assim, o que é dito como dificuldade, localizado no passado, parece se referir a uma condição financeira inferior, associada a 
quantidade de filhos que se tinha, e a facilidade, também no passado, parece se referir à uma menor exigência de consumo.

Porque antigamente era, eu acho que...ainda era mais difícil do que hoje. Hoje é difícil e antigamente eu acho que ainda era mais porque...evoluiu muito, né, de antigamente pra... pra cá, né. Mas, é... tinha muitos filhos não tinha condições de dar ... quase nada para eles, né. Hoje a gente não pode dar nada, mas dá mais do que antes. Eu acho assim.

Porque antigamente, pelo que eu vejo falar que ouvi das pessoas mais velhas eu acho que era muito mais fácil, entendeu? Não tinha esta coisa toda de tudo que tem hoje, né, que tem que dar pros filhos tem que t- Aquela coisa toda, né? Eu acho que é... antigamente era mais fácil, eu acho. Porque hoje você tem que batalhar muito, em tudo, em tudo, que você tem que ter hoje, você tem que batalhar muito, entendeu?

A maior quantidade de filhos no passado, que aparece na consideração anterior, surge também e, semelhante ao que foi dito pela fala acima, como sendo fato mais corriqueiro no passado. Nesta narrativa, a entrevistada vê o tempo atual como tempos mais difíceis, em termos financeiros, e credita ao tipo de mulher existente no passado, uma (maior) força e coragem.

Ah, antigamente as coisas eram mais...mais fáceis, antigamente as mães... tinham um monte de filho e tudo mais, eu diria, para criar. Agora no máximo que a gente pode ter é dois. E mesmo assim, as vezes, com dificuldades. E tem muita que tem muita dificuldade financeira (....) Antigamente 
as mulheres eram mais corajosas, sabe, tinham mais vontade.

O mundo em que vivemos é visto como um mundo piorado, menos tranqüilo, que não oferece condições facilitadoras para a criação dos filhos e a supressão de suas necessidades, pelo padrão de vida imposto.

Não, é muito mais difícil porque hoje, hoje o próprio mundo já não ajuda mais quanto antigamente. Antigamente, tudo era mais tranqüilo. Agora cê tem que ter que, uma educação mais... rígida...se bem que antigamente era bem mais rígido mas hoje... o padrão de vida também não ajuda. E o mundo também... esta pior, né, então cê tem que, caminhar, direitinho, passo a passo, para tentar dar o melhor para o seu filho.

(....) ...mas esse ritmo de antigamente e de hoje em dia.. acho que mudou um pouco, viu?

E esta dita nova versão do mundo, piorada, o é também por causa dos perigos que possui e que contribuem para a diminuição da liberdade dos filhos.

Porque o mundo não ajuda, hoje cê sai na rua, não é mais como cê saía na rua antigamente, entendeu? Você podia deixar o menino solto, correndo por aí, hoje não dá muito tem que viver trancado dentro de casa. Eu vejo por esse lado.

Porque... não sei...eu acho que antigamente era mais fácil, agora tá tudo tão mais difícil. Eu não sei se é porque eu nasci no interior. As coisas são mais fáceis, né, de, de certa forma. Porque aqui tem mais recursos, tem mais hospitais, 
posto de saúde, essas coisas, tem creche, que é, é o meu caso, né. E no interior é que... a gente fica mais a vontade ...é I- é... tem mais liberdade,né? Aqui não, é muito preso, as crianças não podem ficar a vontade na rua porque é muito perigoso. Então eu acho que... tá sendo mais difícil ser mãe agora do que antigamente.

Apesar da admiração pela maneira de ser das mães de antigamente, e aqui fica a suspeita que essa admiração se dirige para as próprias mães, quando o assunto é uma mentalidade mais aberta, a mãe de hoje é quem recebe o mérito, o que pode ser interpretado como um enaltecimento da própria imagem como mãe.

Ah, não, é mais liberal, né as mães conversam com os filhos, as mães de antes não era assim. Minha mãe principalmente, ela não era assim. Quem falava mais as coisas eram os outros de fora, não minha mãe dentro de casa, né porque(....) As pessoas, do lado de fora, né, colega mais velha é que falava, porque minha mãe não falava muita coisa.

É diferente a cabeça delas... mudaram muita coisa, né. Hoje está mais para a frente,né. Antigamente elas pensavam mais é...mais atrasado. Tudo não podia. Não pode fazer isso, né. Era mais diferente, antigamente, agora não, agora ser tornou mais tudo, tudo pode, né, é mais fácil, né ?

Ah, porque hoje em dia, né, para educar um filho tem que...saber, né, e não é como antigamente. Bom, isso a minha mãe sempre fala, né, que a educação de hoje mudou muito, né não? Tem que ter mesmo, lutar, né.. ter...aquela garra mesmo para saber educar (....)Ah, o antigamente, pelo que a minha avó fala que... as crianças não é como são hoje, né? 
Estas três narrativas falam de algo que as mães parecem entender como diferente mas, positivo entre os dias de hoje comparado com outrora. Parece existir, implícito, o desejo de protagonizar uma mudança no que se refere a criação dos filhos. Mudança esta que pode significar uma maior liberalidade ou em uma diluição do rigor, portanto do poder, na relação com o filho. BRIOSCHI \& TRIGO (1989), analisando o discurso de jovens, filhas de trabalhadoras, encontram que estas se queixam com relação à falta de diálogo com suas mães, além de sentirem falta de liberdade e vigilância excessiva. "(....) Ao considerarem o diálogo como elemento fundamental para o estabelecimento do bom relacionamento familiar estão, na realidade, propondo uma modificação nas relações de autoridade" (BRIOSCHI \& TRIGO 1989, p.86). Segundo as autoras, há uma pressão para a criação de um espaço familiar mais democrático. Aqui, com as entrevistadas, o interesse em conquistar o diálogo com o filho parece ser sim, um desejo de transformação, ser mãe de forma diferente das mães que possuíram, mas também é uma forma encontrada para influenciar o outro, transmitir-Ihe seus valores, dado o pouco tempo disponível.

É possível vislumbrar também uma queixa quanto ao mundo de hoje, que intrínseco à vida que se leva, de trabalho, e que se reflete no tempo gasto junto ao filho, visto como bastante reduzido e que, no entendimento da entrevistada, acaba por afetar a qualidade da relação com o filho e sua educação. Parece haver a idéia de que a qualidade da relação se traduz em 
melhor bem criar, maior afetividade e respeito, à medida que se passa mais tempo junto ao filho e se dedica mais atenção a este.

\begin{abstract}
Ah, porque antigamente, as mães não, não trabalhavam, né, então tinham mais atenção com seus filhos, não é? E hoje em dia não, nós temos que trabalhar para ajudar, então é diferente. Aí tem que deixar na creche, né, para outras pessoas cuidarem. A gente fica pouco tempo com os filhos da gente. Só a tarde, né, no fim da tarde aí a gente vai dormir, depois só no fim de semana. Então, antigamente eu acho que era melhor. Os filhos, parece, tinham mais ca-num, num digo mais carinho, acho que mais respeito, né, mais educação, no caso. Porque hoje em dia as crianças, é tudo mal criada, né. Tem umas que não, né, mas a maioria são... danadas, né, não sei se é isso, também, não sei o que pode ser. Eu acho que antigamente, que nem, no meu tempo, minha mãe não trabalhava, ficava comigo e com a minha irmã, né, então nós éramos muito, assim apegadas, né? Minha mãe olhava e a gente não fazia mais as coisas, hoje não, meu filho, as vezes, eu tenho que dar uma palma- uma palmada nele, porque não vai, né. Não obedece
\end{abstract}

O entendimento de que havia, de maneira geral, um maior cumprimento das regras sociais, refletidas na dinâmica familiar, se traduz na impressão de que as mulheres de outrora eram mais obedientes. É possível pensarmos que esta mulher a que se referem eram as suas mães que, mais obedientes, educaram seus filhos, as entrevistadas, de maneira mais rigorosa, reflexo de sua própria educação. Porém, o mundo de hoje, com as transformações que sofreu, não possibilita mais a criação dos filhos da maneira como se dava antes, o que, por sua vez, afeta a relação mãe/ filho 
nos dois vetores, no que diz respeito a educação, maior preocupação, maior dedicação, obediência e até mesmo, como vimos, o respeito e a afetividade.

Não, eu acho que não. Acho que é diferente porque cada... renovação vai sendo uma criação diferente, né. Ãh... a criação da minha mãe foi uma, a minha outra e da minha filha já está sendo outra

Não. Não é bem diferente, porque as mães de antigamente sabiam o que estavam fazendo, né (....)né ouviam conselhos das mães, dos pais, né e hoje não hoje em dia as pessoas não escutam mais, mãe, pai. E faz o que der na cabeça.

Totalmente diferente! É...antigamente é... casamento a mulher era submissa, né? É...o marido falava a mulher acatava, né? Então, se o marido falava se- o filho não vai sair, o filho não saía.

Ah, não, não são não. As mães de hoje em dia não tão nem aí, né? As de antigamente, elas se preocupavam mais... (pausa) Não é igual a antigamente.

E há também, quem ache que a maneira de ser mãe não se altera qualquer que sejam os tempos. O que pode ser marca também de um mito, que discutimos na categoria "o pleno", o mito que as mães são sempre a mesma, em essência.

É. É o mesmo, né? Mãe é sempre a mesma.

Acho, tudo igual. 
Podemos perceber um desejo ainda um tanto frágil de mudança, no sentido de, dadas as atuais circunstâncias de tempo e trabalho, transformar a forma de se relacionar com os filhos.

Com a exceção de assuntos que perpassam a questão financeira, o passado parece possuir uma certa áurea cativante muito ligada à figura de força, delegada às próprias mães. Temos de considerar aqui que pensar nas mães no passado é pensar na própria infância, o ponto de vista de uma criança, o que, pode estar contribuir para esta imagem de força e respeito vinculada às mulheres de outrora, como também pode estar promovendo, como vimos, a idéia de que antes a vida era mais certa, mais preenchida de certezas, as coisas ocorriam de forma mais linear.

De todas as formas, podemos observar aspectos que demonstram existir muitas permanências na ordem existente, mas parece haver o indicativo de uma sutil mudança, algo que é muito mais uma adaptação das estruturas familiares às conjunturas sociais mas que, pode contribuir para um começo de transformação, na maneira de se pensar a família. 


\section{CAPÍTULOV \\ UMA SÍNTESE, UMA REFLEXÃO.}

\section{UMA SÍNTESE, UMA REFLEXÃO}

No grupo de mulheres estudado, ser mãe é percebido como sendo o destino natural da mulher, e este destino pode representar uma mudança no status quo tanto em seu aspecto objetivo, que significaria sair do papel de filha para o papel de dona de casa e mãe, como subjetivamente, significar um amadurecimento, um "tornar-se verdadeiramente mulher", o que demonstra que a construção da identidade esta fortemente vinculada à maternidade. Tanto no desejo de ser mãe, como na maneira de ser mãe, encontramos uma grande influência de antigas ressonâncias, disseminadas em nossa sociedade há pelo menos duzentos anos: a presença obrigatória deste desejo na mulher e a maneira de ser uma boa mãe. É preciso considerar aqui que o grupo estudado pertence a uma camada mais popular, que se utiliza de serviço público e possui renda pessoal, em torno de dois salários mínimos. Isto pode implicar em expectativas profissionais ou de emancipação financeira distintas de camadas pertencentes a um círculo mais abastado, ou mesmo mais intelectualizado, que deposita maior importância naquilo que diz respeito à uma realização profissional. As mulheres aqui estudadas, parecem ter como principal expectativa, terem sua própria casa e criar seus filhos, preferencialmente junto a um companheiro. 


\section{CAPITTULOV \\ UMA SÍNTESE, UMA REFLEXÃO.}

Esta preferência reflete o desejo de reproduzir o modelo burguês de família que também fortalece a construção da própria identidade. Casar significaria uma melhoria de vida, uma melhoria no que se refere ao lugar ocupado no interior da família, como também na sociedade. E, significa também, tornarse verdadeiramente mulher.

A maneira de ser mãe é marcada pela absolutização do ser, demonstrando certa imobilidade no que se refere à idéia de mãe, ou seja, uma eternalização no modo de pensar esta maneira de ser mãe. Desta forma, ser mãe constitui-se para estas mulheres algo que não possui meio termo no que se refere a ser uma mãe boa ou má, transformando o comportamento materno em algo de grande exigência, já que não aceita nenhum tipo de relativização. Esta rigorosidade de pensamento também contribui para a idealização da mulher enquanto mãe, desumanizando-a, já que nega e despreza nela, os sentimentos que estejam distantes dos altruísticos. Ser mãe parece representar algo que deve ser bom, é o destino de toda a mulher e, uma vez mãe, o sacrifício e a doação fazem parte do perfil da mãe. Obviamente, tudo isto, além da precariedade financeira, torna o cotidiano duro de viver, o que faz com que algumas entrevistadas tenham uma ponta de decepção diante do sonho frustrado de possuir um companheiro para dividir as responsabilidades familiares, que são grandes. 


\section{CAPÍTULOV \\ UMA SÍNTESE, UMA REFLEXÃO.}

A ausência de um companheiro é vivida como um peso em termos de cuidados com a família. O companheiro parece representar, para estas mulheres, a possibilidade de minimizar todas as responsabilidades, das financeiras às morais, como também eliminar o ônus social de ser uma "mãe solteira".

Se ver ao lado de um companheiro contribui na construção da identidade feminina, desde muito cedo. A idéia de buscar um companheiro parece corresponder a uma tentativa de alcançar certa adequação da maternidade, que já existe, marcada pelo desejo de colocá-la no seio de uma família tradicionalmente constituída, com mãe, pai (ou companheiro) e filhos. A questão de ser mãe sem a presença de um companheiro e o fato de precisar trabalhar para obter o sustento parecem fragmentar a identidade feminina desta mulher.

A maternidade passa a representar o principal marco para a construção de uma identidade pessoal e social, como também parece ser este o eixo mais importante da vida cotidiana. A transmissão do que vem a ser mulher parece acontecer precocemente e as entrevistadas mostram, por diversas vezes, as influências de suas mães em seu modo de perceber a maternidade. Desta forma, a construção desta identidade, também apoiada na identificação com a mãe ou a avó, parece apoiar-se ainda na concepção 


\section{CAPITULOOV \\ UMA SÍNTESE, UMA REFLEXÃO.}

de que a função principal da mulher é ser para o outro, e o supra exemplo de ser para o outro, é ser mãe.

A educação passa a se constituir uma das principais e, certamente, a que demanda maior tempo e dedicação, função materna. Educação é pode ser pensada não só como instrução como também transmissão de valores caros à família. As mulheres entrevistadas se consideram incapazes de disciplinar seus filhos como suas mães o fizeram e apontam a falta de tempo como principal motivo para isto acontecer. Achar que é pouco o tempo passado junto ao filho provoca culpas que, por sua vez, justificam uma tolerância maior e mais diálogo na relação mãe/filho(a).

A responsabilidade e o trabalho dobrado, que derivam do exercício da maternidade e da jornada de trabalho remunerada, fazem com que as mãe regulem a quantidade de filhos que pretendem ter, na tentativa de manter ou melhorar as condições de vida. A luta empreendida para se manter as vidas, quando se trata de prover o sustento, como também de cuidar dos filhos, é árdua e conta, muitas vezes, com a necessidade do auxílio de outra pessoa e, freqüentemente, esta pessoa é outra mulher.

Por outro lado, é nessa luta que parece residir a percepção de um amadurecimento enquanto pessoa, um aval de adultície e maturidade que é revelado na ponta de orgulho existente nas narrativas que falam dessas batalhas cotidianas. Mas é importante ressaltar que as mulheres consideram 


\section{CAPÍTULOV \\ UMA SÍNTESE, UMA REFLEXÃO.}

grande a sobrecarga que representa esta vida de dupla jornada, sem companheiro e pertencendo a uma camada pobre da população.

Há controvérsias entre os aspectos positivos e os aspectos negativos levantados entre o passado e hoje em dia. As diferenças apontadas entre estes dois momentos são apoiadas na experiência pessoal, ou seja, o que é chamado de passado aqui, diz respeito a um passado bem recente, no passado enquanto filha e, o que é chamado de hoje em dia, é o agora, enquanto mãe. Sob esta perspectiva, as entrevistadas compreendem que as mães do passado, ou seja, as suas próprias mães, não trabalhavam fora e, consequentemente, podiam dedicar maior atenção à educação de seus filhos. Em contrapartida, o fato de trabalharem fora associado a menor quantidade de filhos, ameniza as dificuldades financeiras da família de hoje. Antes, as famílias eram maiores, a condição financeira mais precária, mas não era tanta a necessidade de comprar e consumir; hoje as famílias são menores, melhor o poder aquisitivo, mas é identificada uma maior necessidade de comprar e consumir. Contudo, há narrativas que vêem o tempo atual mais difícil em termos financeiros, justamente devido ao apelo consumista.

Quando o assunto é um relacionamento com mais abertura, se vêem mais modernas que suas mães e, com base naquilo da qual aparentemente se queixam, a falta de disciplina e rigor, parece se sustentar, sutilmente, um 


\section{CAPÍTULOV \\ UMA SÍNTESE, UMA REFLEXÃO.}

desejo de tranformação na forma de se relacionar com seus filhos, mais flexibilidade que a maneira que ela própria foi criada.

De maneira geral, o mundo atual é identificado como mais perigoso, até mesmo mais pernicioso, mas esta crítica ao mundo moderno é intrínseca à vida que se leva, tendo que buscar no trabalho fora de casa alguma renda e, consequentemente, ficando menor o tempo para cuidar de seu filho. Este tempo reduzido junto ao filho é interpretado como obstáculo para a educação dele, da forma considerada mais conveniente.

O que parece ocorrer é que, de uma maneira geral, as entrevistadas distinguem o passado como sendo um período mais organizado, mais linear, período no qual as regras sociais eram cumpridas e, ao contrário, hoje, com a vida que possui, com o trabalho, com a falta de tempo, percebem o mundo em volta de forma mais caótica. Se, por um lado, é verdade que no passado a obediência, seja dos filhos, seja da própria mãe, é um traço marcante e pode levar a uma idéia de organização, muito provavelmente, esta percepção se vincula também ao fato de outrora as entrevistadas serem crianças e, atualmente, serem mulheres com responsabilidades.

Podemos dizer que, apesar das contradições, ou talvez devido mesmo a elas, é possível pensarmos que surge, ainda que de forma tênue, uma transformação na maneira de se pensar a família. Esta transformação parece se referir ao modo como se relacionam com o filho(a), de uma 


\section{CAPITTULOV \\ UMA SÍNTESE, UMA REFLEXÃO.}

maneira mais aberta e com menos imposições e, talvez, na tênue ponta de orgulho que demonstram quando falam da luta diária que enfrentam.

Os relatos sobre um momento ruim que em todas as narrativas se referiram a um momento de perigo pelo qual o filho(a) passou, faz-nos indagar o porque de não ocorrer para nenhuma das mães relatar um momento de conflito, de tensão, no relacionamento com o filho(a). Será que estes nunca ocorrem? Será que não são vistos como ruins, desgastantes? Bem, como já dissemos anteriormente, os episódios escolhidos possuíam a força da vida e da morte, ou talvez melhor dizer, da proteção ou não, da vida. A proteção da prole diante do perigo talvez seja o aspecto apontado como o mais remoto e primitivo traço da maternidade, entre as fêmeas em geral, o que nos remete à questão bionaturalista e à questão da essência, traduzida como instinto materno. Ora, defender o filho significa acima de tudo ser uma boa e corajosa mãe, e, não saber protegê-lo, não obstante muito amá-lo, significaria reconhecer não ser uma boa mãe, ou não ser ainda , uma boa mãe, provocando, desta forma, intensa culpa no simples fato de rememorar algum episódio ilustrativo disto. O que chama a atenção é mais uma vez a enorme proibição de externalizar sentimentos que falem contra a perfeita dedicação, proteção e amor que toda boa mãe deve possuir integralmente no tempo e no espaço. Duríssima exigência, esta, que nega a coexistência de sentimentos antagônicos, que, quando aceitos, significam 


\section{CAPÍTULOV \\ UMA SÍNTESE, UMA REFLEXÃO.}

um maior crescimento do indivíduo, já que são existentes em qualquer relação humana. Por outro lado, como nos aponta LINS (1997), parece que em nosso século há uma grande culpa materna, as mulheres sofrem constante patrulhamento, velado ou explícito, de sua conduta como mães e a sensação de se estar transgredindo o modelo de boa mãe deixa-a vulnerável e angustiada.

Quanto aos relatos sobre um momento bom, o que foi trazido dizia respeito a uma aquisição cognitiva ou psicomotora do filho(a) e, houve também, muitas entrevistadas que se remeteram ao nascimento para exemplificar este momento. A celebração destas aquisições como sendo o exemplo feliz de convívio nos mostra que as mães consideram também suas, as conquistas de seus filhos. Isto é facilmente compreensível, uma vez que tanto empenho é dedicado para o crescimento e desenvolvimento da criança até mesmo antes desta nascer. Cada conquista, sendo esta sempre concreta e aparente, pode ser vista não só pela mãe, mas também pelo pai e por todos em geral, como uma vitória, um atestado de cumprimento dos deveres, um atestado de boa mãe. Evidentemente, ocorre um crescimento e desenvolvimento da criança e, de fato, isto se deve em grande parte aos cuidados do adulto que está mais próximo à criança, no caso, a mãe. Mas, sobretudo, as mães demostram quão gratificante é o reconhecimento desta dedicação e de sua pessoa, pelo seu filho. À medida em que a criança dá 


\section{CAPÍTULOV \\ UMA SÍNTESE, UMA REFLEXÃO.}

respostas aos estímulos e interage com a mãe e com todo o entorno, capacitando-se pouco a pouco e, adquirindo a consciência da própria existência e da existência do outro, maior vai ficando a possibilidade de relacionamento e mais intenso o reconhecimento da existência da mãe, o que parece reforçar não apenas o empenho e os afetos mas também reforça a identidade materna. Os resultados decorrentes do desenvolvimento e do crescimento são surpreendentes e comoventes para qualquer pessoa, saber-se o principal responsável na manutenção desta vida é motivo de orgulho e provoca sensação de grande realização também para qualquer um, ou seja, parece reforçar, pelo gratificante que é para a mãe, o sentido do ser mãe.

Adaptar-se às exigências da sociedade atual, às transformações da família, não é apenas mudar o aspecto "operacional" da maternidade, estes já passaram a ser diferentes do que eram antigamente, mas sim da própria idéia de maternidade adaptar-se a um contexto que mudou profudamente.

A maior participação da mulher na vida pública, ou seja, nas mais diversas esferas da sociedade, promoveu e promove, importantes redefinições práticas e ideológicas na vida das pessoas sobretudo, na vida dessa mulher. Mas, apesar dessas mudanças históricas e sociais, há ainda uma grande pressão ideológica para que as mulheres se sintam obrigadas a se tornarem mães. A sociedade incentiva o desprezo ou piedade por 


\section{CAPÍTULOV \\ UMA SÍNTESE, UMA REFLEXÃO.}

mulheres que não têm filhos e condena aquelas que não os queiram, provocando, na melhor das hipóteses, culpa e frustração.

É preciso que se repense mais profundamente na mentalidade que vê a mulher primordialmente enquanto mãe. Levando-se em conta a inserção da mulher na sociedade atual, é preciso também que se criem caminhos de aceitação e apoio para o desejo de não ser mãe, de tal maneira que haja menos culpa e angústia vinculada ao ser ou não, mãe, fazendo mais viável a possibilidade de uma real escolha entre uma coisa e outra. Podemos nos empenhar em difundir que, cuidar do bebê e depois da criança e adolescente que este se tornará, pode representar um privilégio e um prazer a ser dividido entre homens e mullheres, caso assim o desejem e se disponibilizem, e isto merece o apoio concreto da sociedade. 


\section{REFERÊNCIAS BIBLIOGRÁFICAS.}

\section{REFERÊNCIAS BIBLIOGRÁFICAS}

Alves $\mathrm{E} S \mathrm{~F}$. Análise das representações sociais. In: Spink $M \quad J$, organizadora. O conhecimento no cotidiano. São Paulo: Brasiliense; 1993. p.109-39.

Araújo E. A Arte da sedução: sexualidade feminina na colônia. In: Del Priore M, organizadora, Bassanezi C, coordenadora. História das mulheres no Brasil. São Paulo: Contexto; 1997. p.45-77.

Ariès P. História social da criança e da família. Rio de Janeiro: Zahar; 1978.

Badinter E. Um amor conquistado: o mito do amor materno. Rio de Janeiro: Nova Fronteira; 1985.

Bassanezi C. Mulheres dos anos dourados. In: Del Priore M, organizadora, Bassanezi C, coordenadora. História das mulheres no Brasil. São Paulo: Contexto; 1997. p. 607-39.

Bee H. A criança em desenvolvimento. São Paulo: Harbra; 1984. 
Birman J. Interpretação e representação na saúde coletiva. Physis Rev Saúde Coletiva 1991; 1 (2): 7-22.

Bock A M B. Eu caçador de mim: pensando a profissão de psicólogo. In: Spink M J, organizadora. O conhecimento no cotidiano. São Paulo: Brasiliense; 1993. p. 280-91.

Sheibe K E, Bosi E, Bastos E R, Costa M R et al. Os bastidores da pesquisa. Bol do Grupo Pesq Ident Soc 1984; (4): p14-29.

Brioshi L R, Trigo M H B. Família: representação e cotidiano- reflexão sobre um trabalho e campo. São Paulo: CERU/CODAC/USP;1989. (Textos, Nova Série,1).

Carvalho, L F. Divorced fathers and their views about their relationship with their children. London; 1996. [MSC Dissertation - Tavistock Clinic Brunnel University ].

Carvalho, L. Famílias chefiadas por mulheres: relevância para uma política social dirigida. Rev Serv Soc 1998; 19 (57): 74-98. 
Chodorow N. Psicanálise da maternidade: uma crítica a Freud a partir da mulher. Rio de Janeiro: Rosa dos Tempos; 1990.

Del Priore M. Ao sul do corpo: condição feminina, maternidades e mentalidades no Brasil Colônia. Rio de Janeiro: José Olimpio/ Edump; 1993.

Del Priore M. Magia e medicina na Colônia: o corpo feminino. In: Del Priore M, organizadora, Bassanezi C, coordenadora. História das mulheres no Brasil. São Paulo: Contexto; 1997. p. 78-114.

Erikson E H. Identidade, juventude e crise. Rio de Janeiro: Zahar; 1976.

Falci M K. Mulheres do Sertão Nordestino. In: Del Priore M, organizadora, Bassanezi C, coordenadora. História das Mulheres no Brasil. São Paulo: Contexto; 1997. p. 241-77.

Ferreira $A B$ H. Novo dicionário Aurélio da língua portuguesa. $2^{\circ}$ ed. Rio de Janeiro: Nova Fronteira; 1996. 
Figueiredo F. Mulheres nas Minas Gerais. In: Del Priore M, organizadora, Bassanezi C, coordenadora. História das mulheres no Brasil. São Paulo: Contexto; 1997. p. 141-88.

Fonseca C. Ser mulher, mãe e pobre. In: Del Priore M, organizadora, Bassanezi C, coordenadora. História das mulheres no Brasil. São Paulo: Contexto; 1997. p. 510-53.

Freud A. O ego e os mecanismos de defesa. Rio de Janeiro: Civilização Brasileira; 1983.

Ginzburg C. Sinais: raízes de um paradigma indiciário. São Paulo: Companhia das Letras; 1989. Mitos, emblemas e sinais: morfologia e história; p.143-79.

Giulani P C. Os movimentos de trabalhadoras e a sociedade brasileira. In: Del Priore M, organizadora, Bassanezi C, coordenadora. História das mulheres no Brasil. São Paulo: Contexto; 1997. p. 641-78.

Granjo M H B. Agnes Heller: filosofia, moral e educação. Petrópolis: Vozes;1996. 
Grisci C L I. Mulher- mãe. Psicol Ciênc Prof 1995; 15: 12-7.

Hall C. Sweet home In: Perrot M, organizadora. História da vida privada. São Paulo: Companhia das Letras; 1991. v. 4, p. 52-87.

Heller A. O cotidiano e a história. São Paulo: Paz e Terra; 1970.

Hunt L. Revolução francesa e vida privada In: Perrot M, organizadora. História da vida privada. São Paulo: Companhia das Letras; 1991. v. 4, p. $21-51$.

Ibañez T. Contruccionismo e psicologia. Rev Interam Psicol 1993; 28: 10523.

Kitzinger S. Mães: um estudo antropológico da maternidade. Lisboa: Presença; 1978.

Klein M, Riviere J. Amor, ódio e reparação. São Paulo: Imago/EDUSP; 1975.

Lane M S T. Usos e abusos do conceito de representação social. In: Spink MJ, organizadora. $\mathrm{O}$ conhecimento no cotidiano: as representações 
sociais na perspectiva da psicologia social. São Paulo: Brasiliense;1993. p. 58-84.

Laplanche J, Pontalis J B. Vocabulário da psicanálise. $3^{\mathrm{a}}$ ed. São Paulo: Martins Fontes; 1967.

Lefaucheur N. Maternidade, família, Estado. In: Thébaud F, Duby G, diretores. História das mulheres no Ocidente. São Paulo: Ebradil; 1991. v.5, p. $30-93$.

Leite C L P. Mulheres: muito além do teto de vidro. São Paulo: Atlas; 1994.

Lins R N. A cama na varanda: arejando nossas idéias a respeito de amor e sexo. Rio de Janeiro: Rocco; 1997.

Macedo R M S. Conceito de identidade do ego. Bol Grupo Pesq Ident Soc 1983; 2: p. 26-38. [Anais do $1^{\circ}$ Encontro Interdisciplinar sobre Identidade, São Paulo, PUC/SP; 1983].

Maciel A A. Serl estar pai: uma figura de identidade. São Paulo: 1994. [Dissertação de Mestrado - Faculdade de Saúde Publica da USP]. 


\section{REFERÊNCIAS BIBLIOGRÁFICAS.}

Moreira M T M. Maternidade. São Paulo: Brasiliense; 1993.

Novelino A M. Maternidade: um perfil idealizado. Cad Pesq 1988; 65: p.21-9.

Paula D M B. Gravidez na adolescência: uma estratégia de inserção no mundo adulto. São Paulo: 1992. [Dissertação de Mestrado - Pontifícia Universidade Católica de São Paulo].

Pedro J M. Mulheres do Sul. In: Del Priore M, organizadora, Bassanezi C, coordenadora. História das mulheres no Brasil. São Paulo: Contexto; 1997. p. $278-321$.

Perrot M. A família triunfante. In: Perrot M, organizadora. História da vida privada. São Paulo: Companhia das Letras; 1991. v. 4, p. 93-103.

Perrot M. Figuras e papéis. In: Perrot $M$, organizadora. História da vida privada. São Paulo: Companhia das Letras; 1991. v. 4, p. 120-85.

Perrot M. Funções da família. In: Perrot M, organizadora. História da vida privada. São Paulo: Companhia das Letras; 1991. v. 4, p. 104-19. 
Pidgeon N, Henwood K. Grounded theory: practiccal implementation. In: Richardson J, editor. Handbook of qualitative research. London: BPS Books; 1996. p. 86-101.

Pidgeon N. Grounded theory: theoretical background. In: Richardson J, editor. Handbook of qualitative research. London: BPS Books; 1994. p. 75-85.

Pires A . Ressonâncias: as ciladas da imprensa. Psicol Ciênc Prof 1996; 16 (2): 38- 41 .

Rago M. Trabalho feminino e sexualidade. In: Del Priore M, organizadora, Bassanezi C, coordenadora. História das mulheres no Brasil. São Paulo: Contexxto; 1997. p. 578-606.

Reis O A R. O discurso da saúde pública sobre a adolescente grávida: avatares. São Paulo:1993. [Tese de Doutorado- Faculdade de Saúde Pública da USP] .

Rennie D, Phillips J, Quartaro G. Grounded theory: a promissing approach to conceptualization in psychology? Can Psychol 1998; 29 : 139-49. 


\section{REFERÊNCIAS BIBLIOGRÁFICAS.}

Rodó A, Rivera D. La mujer e su corpo: disociacion y conflito. In: Sexualidad y reproduccion hacia la construccion de derechos. Santiago de Chile: Corsaps/ Flacso; 1994.

Sá C $P$ de. Sobre o núcleo central das representações sociais. Petrópolis: Vozes; 1996.

Santos L S. Adoção: da maternidade à maternagem: uma crítica ao mito do amor materno. Rev Serv Soc 1998; 19 (57): p.99-108.

Silva R C. A formação em psicologia para o trabalho na saúde pública. In: Campos F C B, organizadora. Psicologia e saúde: repensando práticas. São Paulo: Hucitec; 1992. p.25-40.

Sohn A M. Entre duas guerras: os papéis femininos em França e na Inglaterra In: Thébaud F, Duby G, diretores. História das mulheres no Ocidente. São Paulo: Ebradil; 1991. v.5, p. 115-45.

Soihet R. Mulheres pobres e violência no Brasil urbano. In: Del Priore $M$, organizadora, Bassanezi C, coordenadora. História das mulheres no Brasil. São Paulo: Contexto; 1997. p. 362-99. 
Spink MJ, Gimenes M G G. Práticas discursivas e produção de sentido: apontamentos metodológicos para a análise de discursos sobre a saúde e a doença. Saúde Soc 1994, 3: 149-71.

Spink MJ. Desvendando as teorias implícitas: uma metodologia de análise das representações sociais. In: Jovchelovitch S, Guareschi P, organizadores. Textos em representações sociais. São Paulo: Vozes;1994. p. 117-145.

Spink, M.J. O estudo empírico das representações sociais. São Paulo Brasiliense,1993. O conhecimento no cotidiano: as representações sociais na perspectiva da psicologia social. p.86-108.

Strauss A, Corbin J. Grouded theory methodology. In: Denzin N K, Lincoln Y S, editores. Handbook of qualitative research. London: Sage Publications; 1994. p. $273-84$

Thébaud F. A grande guerra: o triunfo da divisão sexual. In: Thébaud F, Duby G, diretores. História das mulheres no Ocidente. São Paulo: Ebradil; 1991. v.5, p. 30-93.

Vaitsman J. Flexíveis e plurais: identidade, casamento e família em circunstâncias pós- modernas. Rio de Janeiro: Rocco; 1994. 
Verucci F. Machismo e os direitos da mulher. In: Da Costa R P. Macho, masculino, homen. $4^{\mathrm{a}}$ ed. Porto Alegre: L\&PM; 1986. p.18-21.

Winnicott $D$ W. O ambiente e os processos de maturação: estudos sobre a teoria do desenvolvimento emocional. Porto Alegre: Artes Médicas; 1982.

Wolfang W. Descrição, explicação e método na pesquisa das representações sociais. In: Jovchelovitch S, Guareschi P, organizadores. Textos em representações sociais. São Paulo: Vozes; 1994. p. 149-86. 
ANEXO 1

As entrevistas a seguir possuem cinco questões básicas, a saber:

1. Quando, para você, uma mulher se torna mulher?

2. O que é hoje a coisa mais importante da sua vida?

3. Você acha que isso é importante na vida de todas as mulheres?

4. Se você fosse contar para uma mulher da sua idade, o que é ser mãe, que coisas você falaria?

5. Ser mãe hoje em dia, é igual a ser mãe antigamente?

Todas as palavras que estiverem em negrito foram proferidas pelo entrevistador.

Os nomes são fictícios para a preservação dos sujeitos.

O nome do filho (a) da entrevistada este será substituído por uma letra.

- 1a. Entrevista - MARIA DAS GRAÇAS -

Maria, quando que para você uma mulher se torna mulher?

$\mathrm{Ai}$, a partir do momento que você tem um filho, eu acho que é isso aí. (é isso?) É, você muda completamente. Até então, você não... se importa com nada, você bagunça cê não está nem aí, depois que você tem um filho tudo muda. (hum, hum) Muda mesmo.

E o que é hoje a coisa mais importante em sua vida?

Meu filho. (seu filho)

Você acha que isto, os filhos né, é importante na vida de todas as mulheres?

$\mathrm{Ai}$, eu acho que sim, viu? Filho muda muito. Muda muito na vida da gente.

Bom, se você fosse contar para uma mulher da sua idade (hã) o que é ser mãe, que coisas que você falaria?

( riso)Deixe eu ver... Ah, é tão gostoso ter um filho... te dá carinho... , principalmente quando a criança é super carinhosa, né. Você brinca, você se diverte, quando ele começa a falar... é... começa a andar, é muito divertido, essas coisas de pequenininho, a partir dos 6/7 meses em diante; é tudo divertido, tudo muda quando começa a falar e fala tudo errado é tão bonito, é muito engraçado... deixa eu ver, cê passear com ele no Shopping, ele fala tudo errado, mostra aquilo, mostra aquilo outro, é eu acho legal essas coisas... falar com uma amiga (hã), fico contente... acho gostoso.

E você acha que ser mãe hoje em dia, é igual a ser mãe antigamente?

Não (riso). Não em parte sim, mãe sempre é mãe, né. Mas antigamente eu acho que era mais rígido, acho que era bem diferente. Hoje em dia não, a mãe, acho que tolera tudo... acho que mudou bastante, mudou um pouco, eu acho, esse ritmo... mãe continua a mesma mas esse ritmo de antigamente e de hoje em dia.. acho que mudou um pouco, viu?

Mudou? Você acha que mulher, hoje, tolera mais?

Ah, tolera mais. Mãe tolera mesmo (riso) antigamente acho que era mais difícil. Mãe era mais rígida, era tudo mais certinho.

Hoje, lógico, tem que ser certinho, só que a gente releva um monte de coisas.

Tá certo, obrigada.

É isso mesmo? (riso)

- 2a. Entrevista - MARIA JOSÉ

M, quando para você uma mulher se torna mulher?

A partir dela ser mãe. Aí eu acho que a responsabilidade é bem maior e ela se amadurece mais.

E o que é hoje a coisa mais importante em sua vida?

Para mim, é cuidar da milha filha e do meu esposo, sabe, é uma grande responsabilidade.

A família?

Isso. A família.

Você acha que isso é importante na vida de todas as mulheres?

Eu acho que sim, da minha parte, sim.

Agora, se você fosse contar para uma mulher da sua idade o que é ser mãe, que coisas você diria?

Ah, agora me pegou, ein? (pausa) O que eu diria pra ela? (hum, hum) Como é ser mãe... (... que coisas você falaria... ) É muito difícil, mas... que é bom, é, ser mãe. Eu adoro ser mãe. Só que é muito difícil, para mim é. Pela vida que a gente tem hoje, muito difícil. Mas... é muito gostoso. (hum) pra mim é assim... 
(pausa)

Você diria isso?

É.

E ser mãe hoje em dia, é igual a ser mãe antigamente?

Não. Porque antigamente era, eu acho que... ainda era mais difícil do que hoje. Hoje é difícil e antigamente eu acho que ainda era mais porque... evoluiu muito, né, de antigamente pra... pra cá, né. Mas, é... tinha muitos filhos não tinha condições de dar... quase nada para eles, né. Hoje a gente não pode dar nada, mas dá mais do que antes. Eu acho assim.

Por que você acha que mudou?

Porque evoluiu muito, né, muitas coisas... faz muitos métodos que falam aí (?) Sabe? Cuidar, trabalhar tã direitin- trabalhar, mudou muito.

Tá certo, então M, muito obrigada. É isso.

De nada.

\section{- $\quad$ 3a Entrevista - MARIA DO AMPARO -}

M, quando para você uma mulher se torna uma mulher.

(pausa) É tão difícil... eu a- pra mim eu acho que é a partir do momento que ela... dá a luz, né, a um filho, né, eu acho, né. (hum, hum) pra mim eu penso assim. (hum, hum)

E que é hoje a coisa mais importante em sua vida?

Ah, meu filho. Sem dúvida.

Você acha que isso é importante na vida de todas as mulheres?

Sim.

Agora, se você fosse contar para uma mulher na sua idade o que é ser mãe, quais são as coisas que você falaria?

(pausa e depois fone) Ai meu deus, como que eu posso responder. É tanta coisa, né? Que.. (como se fosse uma amiga, uma pessoa, assim, que você fosse contar, da sua idade) Hum, hum (olha o que é ser mãe, então você falaria que coisas, assim... ser mãe é... ) Ah, eu acho que.. ser mãe tem que... responsabilidade. Tem que... estar preparada para ser mãe. E... que mais.. mãe(?). Ãh, tem mais coisas só que na hora a gente... dá um agá, nem pisca (?)

Eu espero um pouquinho...

(riso) Deixa eu ver, que mais...( pausa)

Pensa na situação, assim, pensa, fecha o olhinho e pensa.. então cê tá com uma pessoa, mulher também, da sua idade, e você vai contar um pouco para ela o que é ser mãe.

Difícil, né, responder essa. (pausa)

Então vou perguntar outra..

(riso) É bom porque...

Você acha que ser mãe hoje em dia é igual a ser mãe antigamente?

Não. É.. nossa! É muito diferente.

Por que?

Ah, porque hoje em dia, né, para educar um filho tem que... saber, né, e não é como antigamente. Bom, isso a minha mãe sempre fala, né, que a educação de hoje mudou muito, né não? Tem que ter mesmo, lutar, né.. ter... aquela garra mesmo para saber educar....e antigamente qual, como que era? Qual- hoje cê...

Ah, o antigamente, pelo que a minha avó fala que... as crianças não é como são hoje, né?

Quando crescem já começam a.... briga, responde, né, etc. Então é completamente diferente, né, do que é hoje.

(ahãn)

Então tá bom, M, é isso.

Só isso?

Só.

\section{- $\quad$ 4a. Entrevista - MARIA DO SOCORRO}

Então M, quando que para você, uma mulher se torna mulher?

Olha, para mim, não vai da idade, né, eu acho que não vai da idade vai da cabeça da pessoa, né, acho que do momento que você já toma uma decisão própria, né fala o que você quer, acha que é certo, né a partir daí eu acho que é o momento certo. (hum,hum,) Concorda? (hum,hum).

O que é a coisa mais importante na sua vida?

Ah, no momento é o meu filho, né, primeiramente, minha mãe, meu pai, né, e deus, né, quer dizer, primeiramente deus, né, segundo meu filho, porque sem deus a gente não é nada, né. 
Você acha que isso que você falou é importante na vida de todas as mulheres?

ANEXOS

Olha eu acho que.... a maioria das mulheres pensam assim, né, eu, eu creio, né que algumas delas pensam assim, né, porque se colocar deus primeiramente na sua vida em tudo, tudo dá certo, (hum,hum) não é verdade?. Que a gente sem deus não é nada.(hum,hum) Não é verdade?

Se você quiser dizer mais alguma coisa, pode dizer.

Então, né, fica mais fácil quando a gente tem deus na nossa vida. A gente coloca tipo .....a gente tá no... assim esta passando uma fase difícil. Tem muitas mães que vivem separadas dos maridos,né. Muitas faz... sei lá se joga do prédio, faz loucuras, joga até as crianças,né, como já aconteceu um caso, um dia desses aí, não sei se você ficou sabendo, né. É....colocaram uma criança, né, numa porta e... uma, assim, uma... uma patroa que pegou, né pra, para criar a criança, entendeu? Então, cê- a pessoa que não tem deus na vida, né, leva a fazer isso.(hum,hum). Não é verdade? (hum,hum) Eu acho as- eu penso dessa forma, fica mais fácil.

E se você fosse contar para uma mulher, uma menina, da sua idade o que que é ser mãe, que coisas você contaria, que coisas você falariapra ela?

Olha, ser mãe é maravilhoso. Eu contaria pra elas, ser mãe muda muito a vida de uma mulher, né. A partir do momento em que uma pessoa fica grávida, sabe, é diferente, sabe, é muito diferente. A gente se torna, assim, importante a gente dá mais valor à vida. Sabe, é uma vida que tem dentro da gente, né, sei lá, é diferente, né. Eu daria esta opinião, (hum,hum) né, esta sugestão. (hum,hum)

E você acha que ser mãe hoje em dia, é igual a ser mãe antigamente?

Humm...como assim?

Que as mães hoje em dia são iguais as mães de antigamente

É diferente, né?

Porque?

É diferente a cabeça delas... mudaram muita coisa, né. Hoje está mais para a frente,né. Antigamente elas pensavam mais é...mais atrasado. Tudo não podia. Não pode fazer isso, né. Era mais diferente, antigamente, agora não, agora ser tornou mais tudo, tudo pode, né, é mais fácil, né ? (hum,hum)

Era isso, obrigada.

Nada.

- 5a. Entrevista - MARIA DE FÁTIMA -

Como é seu nome?

Maria de Fátima.

Quando é que para você, $M$, uma mulher se torna uma mulher?

Ah, depois que tem um filho, né , eu acho, né?

Cê acha.

Acho.

E o que que é hoje a coisa mais importante na sua vida?

É ele. É o A.

Você acha que isso que é importante na sua vida, é importante na vida de todas as mulheres? $\mathrm{Ah}$, eu acho que sim, né, ter um marido, um filho. Apesar que o meu marido morreu, né (fone) Por isso que o mais importante é ele, né, agora.

Agora, se você fosse contar para uma mulher da sua idade o que é ser mãe, que coisas você falaria pra ela?

Hãn, pruma moça?

É, da sua idade.

Se for pra ela ter?

Se você imaginar assim, pode contar assim...

Ah, sei lá, eu acho que é muito difícil, né pra...porque eu moro com a minha sogra, assim, eu ganho pouco, né, e se não fosse ela, não sei como ia estar hoje, porque eu não tenho meu marido, né. Eu acho que tem que pensar muito, né, para depois ter um filho. Se ter condições, tudo bem, né, mas se não tiver....não dá pra ter a- por enquanto, né?

E você acha que ser mãe hoje em dia, é igual a ser mãe antigamente?

Mas como assim, antigamente?

Hoje em dia as mães são iguais ás mães de antigamente?

Ah, não, é mais liberal, né as mães conversam com os filhos, as mães de antes não era assim. Minha mãe principalmente, ela não era assim. Quem falava mais as coisas eram os outros de fora, não minha mãe dentro de casa, né porque...

Quem falava...? 
As pessoas, do lado de fora, né, colega mais velha é que falava, porque minha mãe não falava muita coisa. Ela só falava - toma cuidado, não sei que.. mas isso não é o suficiente,não é mesmo?(hum,hum)

É isso, só, quer falar mais alguma coisa?

Não, só, obrigada.

Brigada a você

- 6a. Entrevista - MARIA TERESA -

Então, ôi, M, quando é que para você, Sandra, uma mulher se torna mulher? Ah, eu acho que é quando ela se torna mãe, né? No meu, no meu ponto de vista.

Antes disso não...

Não, porque tá na fase da adolescência... né, eu acho.

O que é hoje a coisa mais importante em sua vida?

É meu filho.

E você acha que isso importante na vida de todas as mulheres?

Acho sim.

Se você fosse contar para uma mulher da sua idade, uma pessoa como você, uma mulher, é... o que é ser mãe, que coisas falaria?

Ah, ser mãe é.. eu -não tem muita explicação, porque a gente sente, né. É uma coisa maravilhosa, a gente ser mãe né. Ter um... uma coisa- um filho, né, que sai de dentro de você, é muito bom! Apesar dos trabalhinhos que dá, né mas é, eu acho que é muito bom. Ser mãe é ó- é a melhor coisa do mundo, né?(hum,hum)

\section{E você acha que ser mãe hoje em dia é igual a ser mãe antigamente?}

Não.

Não porque?

Ah, porque antigamente, as mães não, não trabalhavam, né, então tinham mais atenção com seus filhos, não é? E hoje em dia não, nós temos que trabalhar para ajudar, então é diferente. Aí tem que deixar na creche, né, para outras pessoas cuidarem. A gente fica pouco tempo com os filhos da gente. Só a tarde, né, no fim da tarde aí a gente vai dormir, depois só no fim de semana. (hum,hum) Então, antigamente eu acho que era melhor. Os filhos, parece, tinham mais ca-num, num digo mais carinho, acho que mais respeito, né, mais educação, no caso. Porque hoje em dia as crianças, é tudo mal criada, né. (hum,hum)Tem umas que não,né, mas a maioria são.... danadas, né, não sei se é isso, também, não sei o que pode ser. Eu acho que antigamente, que nem, no meu tempo, minha mãe não trabalhava, ficava comigo e com a minha irmã, né, então nós éramos muito, assim apegadas, né? Minha mãe olhava e a gente não fazia mais as coisas, hoje não, meu filho, as vezes, eu tenho que dar uma palma- uma palmada nele, porque não vai, né. Não obedece.

Tá certo...só isso?

Só isso.

Muito obrigada.

- $\quad$ 7a. Entrevista - MARIA ANASTÁCIA -

Então,é... M, né?

Isso.

Quando para você uma mulher se torna mulher?

$\mathrm{Ai},($ ?)(riso) é difícil responder. Ah, eu acho que é a partir do momento que ela se sente ...mais madura, acho que é a partir dos...18 anos, mais ou menos...pra mim foi assim, né, a partir dos 18 anos já me sentia, achava preparada para... o que viesse pela frente, porque tive uma vida difícil, trabalhei desde os 16 anos, desde os 16 anos eu trabalhava, né...(hum,hum),aí acho que a partir dos 18 anos, mais ou menos, eu já ..estava preparada.(hum,hum).

O que é hoje a coisa mais importante em sua vida?

O meu filho.(riso)

E você acha que isso é importante pra todas as mulheres?

$\mathrm{Ai}$, eu, eu acho, eu não sei, eu acho que é difrente para cada uma.,né porque tem mães que não, não dá muito importância para os filhos, né, tem filho, mas deixa por aí, com qualquer um, num, num se preocupa, as crianças adoecem, não esta nem aí... agora pra mim é a coisa mais importante., no 
momento, por meu filho posso deixar trabalho, tudo. Pelo meu fiho deixo qualquer coisa. Ele está em primeiro lugar na minha vida. (hum,hum)

Se hã..vo- hã se você fosse contar para uma mulher da sua idade o que é ser mãe que coisas você falaria?

Ah! (riso) Ser mãe é tudo, pra mim. Ser mãe é ser responsável, ser carinhosa, ser amorosa, né, se preocupar com o filho. É uma coisa... que nem todas as pessoas tem o privilégio de conhecer,né. E...pra mim é a coisa m- é uma coisa muito importante, não é? Acho que é isso que eu falaria pra ela. Que a criança, sei lá, é um presente, hoje...apesar de que não é todo mundo que sabe disso infelizmente. Mas pra mim, sempre foi um grande sonho ser mãe. E eu estou adorando (riso), apesar de tudo, né, porque o meu filho é muito....de vez em quando tem que levar no médico, quase sempre,né, ele está sempre doente, quase, mas ..está em primeiro lugar pra mim.

E... cê acha que ser mãe hoje em dia, é igual a ser mãe antigamente?

$\mathrm{Ai}$, eu acho que é diferente (riso).

Porque?

Porque... não sei...eu acho que antigamente era mais fácil, agora tá tudo tão mais difícil. Eu não sei se é porque eu nasci no interior. As coisas são mais fáceis, né, de, de certa forma. Porque aqui tem mais recursos, tem mais hospitais, posto de saúde, essas coisas, tem creche, que é, é o meu caso,né. E no interior é que... a gente fica mais a vontade ...é l- é.. tem mais liberdade.,né? Aqui não, é muito preso, as crianças não podem ficar a vontade na rua porque é muito perigoso. Então eu acho que.. tá sendo mais difícil ser mãe agora do que antigamente.

Antigamente você achava que era mais...

É! No meu caso por ter nascido no interior, era mais fácil.

Em termos, não em tudo, né, porque tem umas coisas que no interior a gente não tem como tem aqui. Tá...tá certo...quer falar mais alguma coisa?

Não, acho que é só.

Então é isso.

- $\quad$ 8a. Entrevista - MARIA DO CARMO -

Pronto. Então a primeira perguntinha: quando para você uma mulher vira mulher?

Quando, a idade?

Não, se torna....

É, depois que é mãe, né?

...pra você...

Pra mim é depois que é mãe.

É...o que é hoje a coisa mais importante na sua vida?

Na minha vida, mesmo, é o L.

É?(riso) É.

E você acha que isso é importante na vi - que é o filho, né, (é) cê acha que isso é importante na vida de todas as mulheres?

Eu acho que sim.

Se você fosse contar pra uma menina, uma mulher na tua idade o que é ser mãe, que coisas você... falaria?

Ah, ser mãe é uma coisa muito boa, né. A gente sente aquele amor da criança... Eles também tem amor com a gente. A gente tem uma pessoa que é amigo da gente sempre. $E$ isso é muito bom. (riso). (E iss..) Só. Porque sempre ele dá alegria pra gente,né, (hum,hum) tem hora de trabalho e hora de alegrias também. Tem hora difícil que é acordar á noite, sempre tem isso não é, mas também tem hora que é muito boa. Eles brincam, eles dão risadinha, falam coisas. Então, s-só isso.

Tá.. e cê acha que ser mãe hoje em dia é igual a ser mãe antigamente?

É. É o mesmo, né? Ss...,mãe é sempre a mesma.

Cê acha que é t- pode ser- bem igual

Acho, tudo igual.

Então tá bom

(riso) Só?

Só.

- $\quad$ 9a. Entrevista - MARIA DE LURDES 


\section{Ẽ̃o fica a vontade (fone) então a primeira ANOS}

seguinte: quando para você uma mulher se torna mulher?

Ah, eu acho que é a partir dela, se ela, se é mãe. Porque quando ela é mãe, acho que ela amadurece mais, ela cresce mais...(hum,hum), ela tem mais responsabilidade, que quando ela é... ela é sózinha, que ela não tem, ela é solteira, ela é isso é aquilo, ela não tem muita responsabilidade, entendeu? E eu acho que a partir que cê é mãe ( fone) que cê tem um filho, você tem uma responsabilidade, você é mais, é...sabe? Passa a crescer mais (hum,hum), entendeu? E... eu acho que é isso! $\mathrm{E}$ a... mulher com a - pra falar - ela tem uma responsabilidade muito grande a partir do filho,né, em tudo, né, na casa, no filho, eu acho que é isso.

\section{E...é...qual é a coisa mais importante na sua vida hoje?}

Minha filha. Ah, meus pais são muito importantes, a... minha vida, tudo pra mim é importante, mas hoje a partir do que tive a minha filha, acho que minha filha é muito mais importante em tudo, tudo, tudo, em primeiro lugar.Não vivo sem ela, acho que...jamais!.

E cê acha que isso é importante pra todas as mulheres?

Olha, eu acho que não, viu? Depende, porque tem hoje, já vi muitas mães dar os filhos, entendeu? Dá os filhos... então as vezes tem mãe, por exemplo já conheço muitas também, meninas que tem filho, num quer nem ver o filho, lá na maternidade mesmo, dá entendeu? Num quer nem ver...eu acho que não são todas. Mãe é mãe, né ,mas eu acho não é- é daquele jeito que as vezes falam mãe é mãe mas eu acho que não é bem isso, né, porque não são todas que tem a responsabilidade. Então... acho que ..é assim.

Tá. E a.., me diga uma coisa, Solineide, se você fosse falar para uma menina, uma mulher da sua idade, assim, o que é ser mãe, que coisas cê falaria?

Olha, na verdade, eu falaria uma coisa que... eu cuido da minha filha sozinha. O pai dela não me ajuda. Ela eu acho que assim trabalhar, batalhar, pra educar os filhos, entendeu? Acho que... acho que o trabalho vem em primeiro lugar para você..te- dar uma vida melhor para o filho, entendeu? Que hoje o estudo tá em p- é...em primeiro lugar, muito importante mas eu a- eu acho que seria isso! Ter responsabilidade, primeiro trabalhar bastante, não ficar, entendeu,, jogando filho na mão de mãe, filho na mão dos outros para cuidar, entendeu? Eu acho que uma pessoa na minha idade, porque eu acho que eu cresci muito depois da minha filha, eu tenho 23 anos, eu tive minha filha ia fazer 20 anos. Então eu acho que eu cresci muito a partir disso, eu cresci muito. Eu acho que o que eu falaria pra's pessoas da minha idade, era isso, né, e ter- eu acho que... chegasse um ponto assim de cuidar para não ter filho, né, cuidar muito bem pra não ter filho, nessa idade, porque a gente se acaba muito também, que é muita responsabilidade pra você... pôr na sua cabeça... que hoje acho que.. na minha idade, acho que jamais tá sendo alguém assim que...pára, a mãe também pensa pra não ter filhos, porque é um pouquinho de trabalho, né. Aliás acho que não é bem pouquinho, é um trabalho dobrado. Acho que é isso..

\section{E você acha que ser mãe hoje em dia é igual a ser mãe antigamente?}

Não, eu acho que não. Acho que é diferente porque cada ...renovação vai sendo uma criação diferente, né. Ãh... a criação da minha mãe foi uma, minha outra e da minha filha já está sendo outra.

0 que muda?

O que mudou, acho que... em tudo. Na educação, eu não sei se a- prá mim eu acho que hoje tá mais rebelde, as crianças, os filhos de hoje andam mais rebeldes, não sei. Porque antigamente, pelo que eu vejo falar que houve das pessoas mais velhas eu acho que era muito mais fácil, entendeu? Não tinha esta coisa toda de tudo que tem hoje, né, que tem que dar pros filhos tem que t- Aquela coisa toda, né? Eu acho que é...

Que antigamente era mais fácil...

Antigamente era mais fácil, eu acho. Porque hoje você... tem que batalhar muito, em tudo, em tudo, que você tem que ter hoje, você tem que batalhar muito, entendeu?

(ahãm) É isso.

\section{- $\quad$ 10a. Entrevista -MARIA DOS REMÉDIOS -}

Então, é... então, fique relaxada que são perguntas simples ( tá) Pra você quando que uma mulher se torna uma mulher?

Pra mim...hum.. como que você quer dizer? Que que você tá querendo dizer com a pergunta, depende, né. É...em questão de sexo ou em questão de que? Que cê perguntou..

0 que você achar que leva uma mulher a se tornar mulher...(pausa) $O$ que que você acha que faz uma mulher realmente se tornar uma mulher..

Eu acho que o amadurecimento, né, a vida, né, a gente aprende com o dia a dia mesmo. Acho que uma mulher nunca se torna realmente uma mulher. A gente vai aprendendo, né, na vida, eu penso assim. (hum,hum)

Tá, e...qual hoje seria a coisa mais importante na sua vida? 
Hoje? A minha filha, né.(hum,hum) Porque depois que eu tive ela, a gente tem um sentido, né, nascea gente aprende depois que a gente casa, tem filho, a gente começa a aprender que não é mais é...é, clubinho, né, boate, essas coisas, tem coisas mais importantes, não é? Prá mim é isso

E você acha que isso e importante pra todas as mulheres?

Ah, eu acho. Que por mais que a pessoa seja moderna, queira viver sozinha, é...ter sua independência, tudo, acho que uma vida, com filho, é necessário, pra a pessoa, né? E é até mais fácil para a mulher a solidão, isso, né, sei lá, do que ter filho, a gente não sente tão só,né?. Que é onde não há claridade, não é? A gente como mulher, ter o filho pra- pra gente, né? A gente é mais mãe. (hum,hum) Prá mim é isso.

E se você fosse... falar com uma ...uma mulher da sua idade,uma menina da sua idade, o que é ser mãe, que coisas falaria pra ela?

Bom, ó, eu tenho sobrinhas, né, que hoje...é... dizem um monte de bobagens, assim, né, que eu fui assim, né, de... é que é a minha primeira vez, tal e..., eu vou abortar ss-essas, essas coisas, né? Então quando fiquei grávida da minha filha, fiquei sabendo que eu tava grávida com 5 meses e meio. Então eu tinha acabado de voltar a falar com meu pai, meu pai não aceitava muito bem meu namoro, né, então, que qui aconteceu, eu fiquei super nervosa, tal e até quis tirar, a F., né, e eu chequei a ir atrás de clínica, para fazer isso,tá, chorava, ele chorava, que a gente tava-o medo era o pai, entendeu? Mas é o que você fez na primeira pergunta, foi o que me amadureceu, foi isso, porque depois que a gente tem fi- uma criança, a gente vê o que qui a gente ia fazer, entendeu? E...aí eu aprendi! Sabe, a sobreviver, que... a parar de ter medo das pessoas, não é porque é pai, ou porque é mãe, ser eu mesma, sabe? Que antes disso eu não tinha personalidade.

Então foi quando eu comecei a caminhar, foi mais por isso, entendeu? Então, é...o que que eu falaria pra uma menina, tá, é... hoje em dia, quando ter relação usar camisinha, porque tem gen- agente não liga para isso. Por mais que venham e avisem, tal, na hora a gente não tá nem aí.

Ah, mas não vai ficar grávida, né a gente não tá nem aí mesmo., então vou tirar fora, que é assim que fazem, né, então falaria isso, ou pensa bem o que qui você tá fazendo. Sabe? Eu não sou contra, até que tenho uma educação boa minha mãe desde pequenininha ensinou a gente, até certo ponto, que ela aprendia ao mesmo tempo, né. Tudo o que ia-perguntava pra ela ela já desconfiava. Então ter um diálogo aberto conversar com outras pessoas, não ter vergonha das coisas, sabe, este tipo de coisa, cê..aprender com a vida, então é como eu falei a gente aprende com a vida, né, o dia a dia, enfrentar os problemas, este tipo de coisa. Que minha sobrinha tá passando mais ou menos por este problema , né, e ela fala: "É, minha mãe é liberal, meu pai é liberal, mas só que eu não sei o que eu quero,né por isso que eu fiquei grávida e tal", né, então eu falaria isso para ela., que é a minha experiência de vida,né, a gente fazer as coisas mas com a cabeça feita. Por isso que eu acho errado, muitas vezes, é...15 anos, 16 anos, a gente já ter sexo, eu acho errado isso. Porque é depois que a gente vai ver, né, que a mãe da gente tem razão. A gente precisa amadurecer um pouco pra poder,né, saber o que qui ta fazendo, né? Então eles colocam tanta coisa, ah, porque é gostoso, ah porque não sei quê, aí a gente, aquilo que prende mais a gente quer fazer mais, né? $\mathrm{E}$ é assim, prá mim é isso...

Então aí tem super a ver é...então, porque a pergunta é assim: cê acha que ser mãe hoje em dia é igual a quan.. ser mãe antigamente?

Não.

O que qui muda?

Totalmente diferente! É...antigamente é... casamento a mulher era submissa, né? É...o marido falava a mulher acatava, né? Então, se o marido falava se- o filho não vai sair, o filho não saía. É...tinha papo que você não conversava com sua mãe, era tudo desconfiança, né. Hoje não,hoje eu - eu até tenho esse problema com a minha filha que eu não sei quando parar, as vezes ela fala: "não, mãe, eu vou, eu vou, eu vou" então eu não sei se eu brigo, que qui eu faço, coisa que minha mãe já iria ali, e bateria em mim ou, né , daria um beliscão, coisa que eu tento hoje, sabe, mudar isso. Então educação hoje é totalmente diferente de antigamente, né. Minha mãe mesmo fala, hoje ela mudou. Hoje, é.. depois de 8 anos, né, do ultimo filho, ela teve, né, uma menina. E.. a nossa educação é totalmente diferente, nossa ela é su-per liberal; minha irmazinha ela conversa com todo mundo, ela não é presa, sabe? Quando a criança é ....tem personalidade., tá? E antigamente não, não deixavam a gente ter personalidade, por isso que eu falo, quando vêm a experiência aí a gente fica, sabe, bate na cabeça, é dificil entender as coisas, tem que quebrar a cara, tem tudo isto que a educação hoje em dia é bem melhor. Você pode conversar com psicólogos, pode levar seu filho vamos dizer, se tem uma separação cê pode levar no psicólogo, pode passar para alguém para te ajudar, para te orientar. Antigamente, não tinha nada disso, né antigamente era no- tranco e barranco, né. (ahãm) $E$ é isso que eu penso.

Tá certo, $M$.

- $\quad$ 11a. Entrevista - MARIA MADALENA - 
Bom M, quando para você uma mulher se torna uma mulher?

Quando é... pra mim é quando ela ser mãe.

Quando ela é mãe?

Isso.

E o que é hoje a coisa mais importante em sua vida?

Ah, tem tanta coisa, viu? (então fala pra mim) É...em primeiro lugar, eu, né, segundo é minha filha, terceiro minha família, minha mãe, meu pai, meu esposo não é muito...muito chegado, né.

E.. essas coisas que você falou, você acha que são importantes na vida de todas as mulheres?

Olha,eu não sei, eu tô falando só a minha parte. Porque tem muita gente que.. não gosta da mãe, não gosta dos pais. Tem muitas mães mesmo,que não gosta do filho, porque tem mãe que bate, é.. machuca as crianças, então essas mães não gostam do filho (hum,hum), né.

Agora.. assim... se você fosse contar para uma mulher da sua idade, uma pessoa na sua idade, o que é ser mãe, que coisas você falaria?

(pausa) É uma pergunta difícil (riso) $\mathbf{O}$ que é ser mãe? Ah, ser mãe é a... acho que é a coisa mais bonita, né, do mundo. Tudo que a gente pode...tudo que a gente pode... é... gerar um filho, sabe, é a coisa mais bonita, assim... para uma mulher. (hum,hum) ...só isso...

E... você acha que ser mãe hoje em dia é igual a ser mãe antigamente?

Não é mesmo. (Não? porque?) Ah, antigamente as coisas eram mais...mais fáceis, antigamente as mães... tinham um monte de filho e tudo mais, eu diria(?) para criar.- Agora no máximo que a gente pode ter é dois. Mesmo assim, as vezes com dificuldades. (ahãn) $E$ tem muitas que tem muita dificuldade financeira (ahãn). Como tem muita, como algumas que eu conheço, né, que...dizer mesmo(?) a mãe, a mãe só fez mesmo e deixou para a avó, né, e o pai matou o sogro, esta preso, então a criança tá jogada. A sorte é que a avó pegou. Então eu acho que...não é certo isso. A mãemulher que é mulher tem que assumir o que faz. (hum,hum)

E antigamente você acha que as mulheres...

Antigamente as mulheres eram mais corajosas, sabe, tinham mais vontade. As vezes se separam do marido, mas mesmo assim tava lá lutando, sabe, agora não, todo mundo agora é tudo na justiça, tudo assim, então, antigamente era mais fácil. (hum,hum,). Agora é mais difícil.

\section{- 12a. Entrevista - MARIA DA CONCEIÇÃO -}

Bom, M, quando para você uma mulher se torna uma mulher?

Ah, acho que quando é mãe, viu .Quando é mãe.

Certo,só?

Com certeza.

O que é hoje a coisa mais importante em sua vida?

Ah, meu filho. Sem dúvida.

E você acha que isso é importante na vida de todas as mulheres?

Eu acho que sim. Acho que desde quando ela se torna mãe, acho que o filho passa a ser a coisa mais importante da vida dela.

Para todas as mulheres?

Para todas as mulheres... que é mãe!

Então, tá, agora...(riso) se você fosse contar para uma mulher da sua idade o que é ser mãe, que coisas você falaria pra ela?

(pausa) As coisas que eu falaria? Que é ser mãe....Ah, ser mãe é educar, é cuidar, é criar, dar o melhor de si, sabe, é ver crescer, é tá junto...

Acho que ser mãe é um todo.

(hum,hum)...Pronto? Só?

Ser mãe hoje em dia é igual a ser mãe antigamente?

Não, é muito mais difícil porque hoje, hoje o próprio mundo já não ajuda mais quanto antigamente. Antigamente, tudo era mais tranqüilo. Agora cê tem que ter que, uma educação mais... rígida...se bem que antigamente era bem mais rígido mas hoje... o padrão de vida também não ajuda. $\mathrm{E}$ o mundo também... esta pior, né, então cê tem que -caminhar direitinho, passo a passo, para tentar dar o melhor para o seu filho.

Então mudou em que? A... que eu perguntei se hoje em dia ser mãe é igual a antigamente, cê falou que não, mudou.

Não, mãe, tudo bem, o sentimento materno eu acho que possa que seja igual, agora, o desenrolar da coisa é diferente. Porque hoje você tem que ter mais atenção, tem que dar mais atenção pro seu filho, educação-educando dentro e fora de casa. Porque o mundo não ajuda, hoje cê sai na rua, não é mais 
como cê saía na rua antigamente, entendeu? (hum,hum) Você podia deixar o menino solto, correndo por aí, hoje não dá muito, tem que viver trancado dentro de casa.(hum,hum) Eu vejo por esse lado.

Certo...entendi...era isso,então...

\section{- 13a. Entrevista - MARIA MACULADA}

Então me diga, (hum) o que qui, para você, faz uma mulher se tornar mulher?

$\mathrm{Ai}$, cê fez uma pergunta que...O que qui eu fa...

O que pra você é uma m-é...quando, pra você, uma mulher se torna vira mulher, se torna mulher

Ah...pra mim uma: ultimamente não tem idade para se tornar mulher, né. Então pra mim...é... quando ela tem responsabilidade (fone). Que ela tem uma responsabilidade, aí ela se torna uma mulher, sabe? Quando ela tem uma cabeça, assim, uma coisa que ela se... fica responsável de alguma coisa...é... pra mim é isso ...sabe...(hum,hum) Porque hoje, hoje em dia não tem idade pra uma- pra uma mulher, ser uma mulher; porque eu tenho 17 anos (riso) (ahãm) E nu-pra mim já não tem mais idade (hum,hum)... ser uma mulher completa e t-, sabe? Não tem.

E a respon-cê acha que é a responsabilidade?

É a responsabilidade.

E - e o que qui seria hoje a coisa mais importante na sua vida?

Para mim hoje... meu filho!(riso) Pra mim, hoje...

E voc- você acha que isso é importante pra todas as mulheres?

Para algumas, nem todas são ...pra algumas é importante ter um filho, ter uma família, um lar, sabe? Ter uma família. Ë.. pra umas são, tem outras que não faz questão de... ter uma....uma família, e... né, isso não é importante na vida delas. (hum,hum).

Cê ia dizer alguma coisa e eu interrompi? antes?

Não, não.

É...se você, então, fosse contar(hum) para uma mulher, uma menina- mulher, da sua idade (hum), o que é ser mãe, que coisas falaria?

Ah, eu falaria -que é ser mãe? Ter responsabilidade com o filho, ter cuidado, ficar preocupada, sabe, se está bem, to-se esta comendo direito, como é que tá, quando fica doente, ficam-algumas mães ficam bem desesperada, entendeu? Isso pra mim é mãe...mãe n- é a vida toda. Uma mulher quando.. dá para ser mãe é a vida toda. Porque ela sempre se preocupa com o filho, até maior. Que hoje em dia (?) é assim , né ....tem algumas não que já num importa tanto, mas....é isso..ss-pra mim é isso ser mãe.

Cê diria estas coisas... (fone)

Ahãm.

(pausa)

E... cê acha que ser mãe hoje em dia é igual a ser mãe antigamente?

Não...nem tanto, nem tanto. Porque antigamente eu acho-as... Mãe antigamente era mais puxado, né, ser mãe antiga..mente era mais puxado, a mãe era muito em cima do filho. Hoje não, hoje tá muito aberto ser mãe, sabe. Não tem mais aquela pegação. Tem mãe que não gosta do próprio filho, entendeu, não tem...essa...hoje em dia o...uma mãe ela já é meia... sabe, meia-não tem aquela-tanta preocupação, assim, com o filho- certos filhos elas têm, certos, não- alguns não. eisso...pra mim...

Então cê acha que não-mudou?

Mudou.Com relação a ser mãe. Antigamente, na minha opinião, antigamente uma mãe não deixava um filho no meio da rua, né. Uma mãe ela tinha...ela tinha que corrigir aquele filho de todo jeito, hoje em dia a mãe num tá conseguindo fazer isso.É difícil, tem umas que até deixa de

Tem umas? Desculpe, não ouvi

Tem umas que é u- deixa de mão (Ah, deixa de mão), não liga mais, eu digo, antigamente já tinha aquela rigidez. A mãe era rígida com os filhos. O pai também. Agora hoje não tem tanto isso.

Mais alguma coisa?

Não,só (riso)

- $\quad$ 14a. Entrevista - MARIA APARECIDA -

Quando, para você, uma mulher se torna mulher?

Quando se torna? A partir do momento que passa ter responsabilidades, que passa...assim, vamos supor, tem um filho, um marido, uma casa, um emprego, ah, passa a ser independente, não precisa mais, tipo assim, da mãe do pai, né, em ambas as partes, porque a gente sempre precisa dos pais, né, (hum, hum) então pra mim é.. é isso.

O que que é hoje a coisa mais importante na sua vida? 
Hoje a coisa mais importante na minha vida é a minha filha.

E você acha que isso é importante na vida de todas as mulheres?

Que.. se isso é importante? Para a maioria. Para a maioria das mulheres um filho é muito importante, tá, porque eu tenho, assim, né experiências, assim, de pessoas, assim, que tem filhos mas não dá aquele valor que a criança devia ter (hum,hum). Prá mim...eu penso assim.

Agora, (hum) se você fosse contar (hum) para uma... uma mulher, da sua idade, (hum) o que é ser mãe (hum), que coisas falaria pra ela?

Que eu falaria para ela? Ser mãe não é fácil. É bem complicado. Tanto que a min... Para mim, ser mãe foi bem complicado, passei por diver.. tanto que eu sou mãe solteira e foi bem complicado, tipo assim, se eu fosse voltar agora atrás, se eu pudesse retornar, eu num.. faria a besteira de ser mãe novamente, né, então assim, mãe solteira, não., porque é muito complicado.

E... a última, você acha que ser mãe hoje em dia, (hum) é igual a ser mãe antigamente?

Não. Não, é bem diferente, porque as mães de antigamente sabiam o que estavam fazendo, né. Hoje muitas mães, muitas meninas, assim da minha idade, assim, porque eu não sou velha mas tambem não sou novinha, tenho só, apenas 22 anos, muitas delas num.. num pensam antes de ter filho, vão fazendo, vai o que der na cabeça só fazendo... e aí, as vezes, vem uma criança indesejável, indesejada que a mãe às vezes dá, joga fora como acontece muito, né. Assim se, se eu fosse, se eu pudesse, eu não teria. Eu num voltaria atrás, né.

E antigamente era diferente?

Pra mim era bem diferente, porque eu tinha minha liberdade. Trabalhava para mim. Agora eu tenho que trabalhar para mim e pra sustentar minha filha e ajudar minha mãe, né, por ser mãe solteira.

Mas ser mãe era diferente?

Se é, nossa! Era bem diferente, porque elas pensavam, né, primeiro se casavam, né, ouviam conselhos das mães, dos pais, né... e hoje não, hoje em dia as pessoas não escutam mais, mãe, pai. E faz o que der na cabeça. Se achar que deve, vai fazendo, vai pondo filhos no mundo, maltratando muito as crianças... para mim só isso... Sei lá, é meu jeito de pensar, eu penso assim,né? Tudo bem? Quer dizer mais alguma coisa?

Não, só isso.

Ótimo.

\section{- $\quad$ 15a. Entrevista - MARIA GORETH -}

Bom, M, quando que, é... para você, quando que uma mulher se torna mulher?

Ãh, mmh... assim, né, eu, eu tornei mulher cedo, né, porque eu tive meu filho com 15 anos. Mas eu acho que uma mulher pra ser mulher não basta só ter um filho, casar, tem que ter responsabilidade (hum,hum), né, que não adianta eu ter um filho, eu ser casada, e daí? Né.. não ter minha responsabilidade, eu acho que ser mulher tem que ss- ser mulher e ter responsabilidade, né, é isso que eu acho.

Qual é a coisa mais importante na sua vida hoje?

Ah, hoje, com certeza é meu filho. (hum,hum)

E cê acha que é, que isso é importante pra todas as mulheres?

Bom, eu acho que não é para todas, porque senão... tem muitas que dá o filho, né, que deixa no meio da rua, que num... nem liga, né, na verdade. Mas prá mim é o meu filho.

Se você fosse falar para uma, (fone) pra uma mulher na sua idade, o que é ser mãe, que coisas você falaria pra ela? (fone persiste, barulho de criança))

Ah, ah... ser mãe é bom, né? Ah, eu gosto de ser mãe. (pausa) Me sinto bem.. né, porque tudo que eu faço é pra ele, é pensando nele, entendeu? Antigamente, eu fazia por fazer, mas agora não, agora eu sei porque que eu faço, pra que, porque tenho uma, uma pessoa que depende de mim, então é isso. Eu acho que ser mãe é ótimo.

E você acha que ser mãe, hoje em dia, é igual a ser mãe antigamente?

Ah, como asim? (fala simultâneamente a mim), pra criar...

As mães de hoje em dia são iguais ás mães de antigamente?

$\mathrm{Ah}$, não , não são não. As mães de hoje em dia não tão nem aí, né? As de antigamente, elas se preocupavam mais, né, trancava mais, prendia mais as crianças hoje em dia...tá liberal (riso), né... (pausa) Não é igual a antigamente.

É isso...

Só? 
ANEXO 2

Todas as palavras que estiverem em negrito foram proferidas pelo entrevistador.

Os nomes são fictícios para a preservação dos sujeitos.

O nome do filho (a) da entrevistada este será substituído por uma letra.

\section{1: MARIA DAS GRAÇAS}

M, bom dia (bate a porta do carro), pode fechar, eu queria saber, eu queria que você lembrasse, uma situação, um exemplo, não precisa ser a coisa melhor, assim, a melhor situação, mas um exemplo onde foi legal, junto com o B, foi boa a situação.

A situação?... Ai, (ri) qual que eu posso dizer? Ai, ele tá aqui comigo, e... gosto muito, deixa eu ver qual a situação (um exemplinho assim, uma vez.. sabe assim? teve uma vez que... ) Ah, quando eu chego em casa, assim as vezes eu chego lá, ele diz assim 'ah, a mãe chegou, a mãe vai me levar pró shopping' aí eu levo ele pró shopping ele se diverte, essa é a parte, que ele não desgruda de mim, essa é a mais maravilhosa (fala rindo) a etapa mais maravilhosa, deixa eu ver..., ah, é que eu não convivo muito com ele, eu não posso dar um assim

É isso mesmo, não é nada, assim, o maior não, é, é um exemplinho mesmo (um exemplinho... ) agora o contrário, eu quero que você me dê um exemplo de uma situação de convívio (ah) junto com ele, que foi chata, foi difícil entendeu?

Ah a chata, difícil é quando ele tá doente, que cê tem que ficar no hospital com ele, que ele fica "ai mãe não quero ficar aqui, quero sair daqui" isso prá mim é é muito chato, doi em mim né, prá mim é chata essa situação viver com isso dói muito em mim né, porque criança quando tá doente é difícil prá qualquer mãe né, acho que é isso uma situação difícil.

\section{Então é isso.}

(risos) Viu como é rápido?

\section{2: MARIA JOSÉ}

Bom dia M, (ri) (bom dia), eu queria saber, eu queria que você lembrasse, recordasse assim, uma situação é.... , como exemplo mesmo, que tivesse sido legal e que você tivesse vivido junto com a T. com ela..

Prá mim, o momento melhor foi o dia que eu ganhei ela, foi uma situação muito boa, na hora que eu acabei de ganhar ela, que jogaram ela em cima de mim foi, foi muito bom, uma sensação muito boa.

Outra pergunta M, que seria o contrário, uma situação que você viveu com a T. que foi difícil, foi chata.

Nossa, graças a Deus ainda não teve assim, uma situação muito difícil mais quando eles- é, ficam doente, é muito difícil a gente fica preocupada....

Um exemplo de uma historinha que foi chata, assim...(pausa) que foi difícil ser mãe naquele momento.

(ri) Sei lá...eu não tenho um difícil assim sabe, sempre foi razoável, não teve um... (conta, o razoável...) (ri) ai... há uns 15 dias atrás, ela ficou doente né, teve uma catapora e.. não deixava eu dormir e nem ela dormia (ri) foi um pouco difícil, uns dias...(tá)... que ela ficou sem dormir e nem deixava eu dormir, mas passou (ri).

Tá certo, brigada. 
$M$, eu gostaria que você me desse... parasse um pouquinho e lembrasse de uma situação que você viveu com o A, você e ele (ãh), e que foi legal, um exemplo de um acontecimento que você viveu com ele que foi legal.

... Hum... ah, todos, prá mim, é todos, né. (mas dá um exemplo) ... um? um exemplo? (é...)Tão difícil né, ah... num lembro um assim...sei lá num lembro...

Num tem pressa (ri) pense assim, uma hora que cê tava com ele (tosse) nesse tempo todo, então, um acontecimento, uma situação que cê falou: "ah que legal, que bom."

(pausa)... Ai, meu Deus, deixa eu ver (ri) é tantos né que nem... (tosse) (cita um, unzinho, não precisa ser o mais legal) um legal, deixa eu ver... (ri) sei...deixa eu ver, um legal, deixa eu pensar.... ah, num, num vem nenhum assim, ah, são vários mas, mesmo assim num consigo lembrar de um... tem... ah... não consigo mesmo viu.

Então vamos fazer o contrário (ah) depois a gente volta.

Acho que eu num tô entendendo a pergunta (ri e tosse).

Então vamos fazer o contrário, lembra de uma situação que cê viveu com o A, que foi dificil, foi chato, que foi, uma situação que cê tava com ele e cê falou "que difícil, que chato".

Ah acho que... ah um momento assim que eu trabalhava, que eu tava sozinha né, e ah, tinha trabalho, prá trabalhar, prá cuidar ele, então esse foi o pior momento né, chato mesmo, porque tá trabalhando e ter que parar prá cuidar dele, acho que esse...foi o mais chato prá mim né (teve que parar de trabalhar?...) é, prá... dar de mamar, trocar fraldas, essas coisas né.

Trabalhando ãh... em casa?

Isso. Casa enorme, sozinha né, então, tinha que... a atenção pros dois, pro serviço e prá ele né, então esse foi o pior.

Hum hum, agora vamos voltar ao exemplo do... de uma situação que foi legal (que foi legal?) que aconteceu, um acontecimento que cê... "ah isso foi legal", um exemplinho, assim.

Hum ...(pausa) hum... isso é tão difícil responder (ri) bom, apesar né, que o outro seria mais difícil, mas essa... né, acho que.... o mais legal é o que eu tô vivendo agora né, que eu tô com ele... mesmo, e ele conversa todos os dias comigo. Que conversa... nossa, que ele fala super bem is... acho que esse é o mais legal que eu tô sin......, que eu sinto né, é só isso (ri) não sei mais (hum hum) que mais?(só) só? (é isso) ai, eu fico assim pensando que primeira vez eu nem perguntei prá... porque essas perguntas assim, porque logo eu?

Mas não é só você...(desligo o gravador)

\section{4: MARIA DO SOCORRO}

Eu queria que cê me contasse $M$, uma situação que cê viveu com seu filho, que foi boa.

Ah... ai prá mim...

Que cê lembra assim...

Ai, foi a partir do momento que ele nasceu né, eu tinha feito o ultrassom né, e ...deu menina né, eu tava esperando menina né, daí na hora que ele nasceu, aí o médico mostrou prá mim era um menininho, e eu fique tão emocionada sabe, porque cê vê, Deus não falha na nossa vida né, Deus tinha falado na palavra, eu sou uma serva de Deus né, cê já percebeu que eu sou crente né, então Deus tinha falado na palavra que ia ser menina- é... um menino, um varão valoroso, o filho da promessa né, e nisso na hora que mostrou um menino, eu fiquei tão emocionada assim, confirmação mesmo, a melhor confirmação de deus né, e era um menino, nossa, acho que era, foi aquele dia prá mim sabe, que eu fiquei tão emocionada, (tá) foi nesse dia...

Agora eu queria o contrário, que cê lembrasse uma situação que cê viveu com o seu filho que foi chata (que foi chata?), que foi difícil... 
Ai tadinho, eu lembro num dia que eu fui dar banho nele né, a primeira vez que eu fui dar banho no $P$., tadinho do meu filho (ri) eu tava de resguardo nesse dia, minha mãe não tinha chegado ainda prá ficar comigo né, e nem minha sogra, e eu fui dar banho no P. e virei ele assim de cabecinha prá baixo né, e ele sufocou tadinho né, na água sabe, ficou sufocado, o rostinho, foi nesse dia que eu fiquei apavorada sabe, porque marinheira de primeira viajem né, $P$. ficou todo roxo, nossa, esse dia foi.... super..... chato prá mim né (ri) fiquei aflita né (ri).

Tá bom, era isso.

\section{5: MARIA DE FÁTIMA.}

$M$, eu queria que você lembrasse de uma situação, assim, parasse prá lembrar de uma situação que você viveu com o A, que foi uma situação legal, uma situação boa ( mas, como assim?) Um exemplo, não preci... um exemplo que você lembre, qualquer...

Boa? de sair, assim, qualquer coisa?

\section{É... que acontec... um acontecimento que cê lembra que foi bom.}

$\mathrm{Ai}$, assim, tem agora recente né, que a gente tava, que ia precisar operar, que ele tem carne esponjosa, e tem... tinha... tava com problema no ouvidinho né, aí por causa do convênio, essas coisas, tem que esperar a carência né, aí...., a gente foi no médico de novo ele falou, que talvez não precise né, aí eu fiquei muito contente né, aí ele falou assim prá gente levar em outubro porque tá melhorando bastante, a gente tá dando remédio né... que ele é tão pequenininho né, prá operar, ai eu acho...esse.... período muito bom.

Hum, mas assim, que cê lembre de um exemplo, de alguma coisa, é... que você viveu junto com o A, que foi legal.

Mas assim, (ri)... tem tantas coisas, ai... eu não sei, como, é assim...dá um exemplo, assim que eu posso falar...

\section{Eu que tô pedindo o exemplo...}

Ah, mas não sei, tem muitos né... ah quando ele nasceu né, foi uma alegria enorme.

Agora o contrário, me dá um exemplo de uma situação que aconteceu, você e o $\mathrm{A}$, e que foi muito difícil, foi chato.

Que foi chato? (ri)...(pausa) é difícil né... assim, ah não sei porque tudo é difícil né? ( por exemplo?) Ah? (dá um exemplo?) ah, que nem, assim tem vez que o serviço da gente é corrido, até buscar ele, tem dia que não dá prá gente buscar, aí a gente pede prá alguma pessoa, prá tia dele assim, não pode, não pode vim buscar, (alguém abre alguma porta barulhenta), aí a gente que tem que fazer, que é a maior correria né, que nem outro dia eu falei prá tia dele buscar e não dava, aí eu vim 4 horas, depois levei ele na minha casa prá mulher cuidar, aí depois vim pro serviço de novo prá terminar de passar roupa, isso é difícil né?

Mas uma situação que você viveu junto com o $A$, (junto com o $A$ ?) você e ele, que foi uma situação chata, uma situação difícil.

Ah, quando ele fica muito doente né, porque ele sempre ficava doente, agora que tá melhorando, por causa desse problema do nariz né, mas com os remédios já tá ajudando bastante, que ele vivia doente, magrinho, magrinho, magrinho, comia nada, agora que ele tá melhorando.

Tá bom...

6: MARIA TERESA.

...De novo, a minha professora mandou eu voltar, aquelas coisas tá, então fica à vontade, numa boa. Eu queria que você se lembrasse um exemplo, uma situação, não precisa ser o maior exemplo, um exemplo qualquer, de uma situação que foi legal que você viveu com o G., não precisa ser a mais legal, um exemplo, uma coisa que você lembre, assim....

(pausa)... ai, teve tantas né, mas a mais assim, né? a que eu achei a mais legal... ah... (a que cê lembra), o momento que eu mais achei legal assim, foi quando ele deu o primeiro sorriso, o primeiro sorriso dele me emocionou muito, ele tinha, acho que uns dois meses, quando ele deu o primeiro sorriso né, acho que foi esse e quando nasceu o primeiro dente dele também 
Tá certo, agora o contrário, eu queria que você lembrasse de uma situação, de um exemplo, não precisa ser o pior, mas de uma situação e um exemplo que foi difícil, foi chato..

Foi quando ele tinha 18 dias, ele, é... eu dei mamadeira prá ele, e coloquei ele deitado, no... no berço né, só que ele se... se mexeu assim um pouco e ficou co... com o rosto assim prá cima, então ele... ele aspirou o leite prá dentro, então a gente saiu correndo pro hospital, saiu leite pelo nariz dele, pela boca, quase que ele morreu... esse foi o pior da minha vida.

Tá certo, então era isso, brigada

\section{7: MARIA ANASTÁCIA}

Oi (risos) $M$, eu queria que cê lembrasse uma situação, com calma, que vo... que fosse uma situação, um exemplo assim de um dia que foi legal, que aconteceu, uma situação legal, é... junto com seu filho.

... Isso é simples (ri) ah, tem várias situações, mas... (Uma que cê lembre) deixa eu ver... ah lembrei, a situação mais legal (ri), a primeira vez que eu vi ele engatinhando, que eu levei ele, daqui da... que ele não tava engatinhando né, então trouxe prá creche, quando cheguei em casa que coloquei ele no chão, ele saiu rapidinho engatinhando, ah eu adorei (ri) (Tá certo...). Adorei dividir com o pai, também ficou super feliz, acho que foi.... até agora, foi a situação mais interessante junto com ele que eu já vivi né...

Tá certo, agora eu queria o contrário, que você lembrasse de um situação que você viveu, um exemplo de....não precisa ser o pior, um exemplo que você lembre, que foi difícil, foi chato junto com o A.

A primeira vez que ele ficou internado, graças a deus a primeira e única, até agora né, eu tava só, o pai dele viajou né, que eu... o pai- o pai do meu marido adoeceu, então ele teve que viajar e... exatamente na semana que ele viajou, meu filho adoeceu, adoeceu teve febre, levei pro médico, passei aquela situação chata, e prá, ficar, de repente faz vários exames, aí, decidir, vai ficar internado e transferir de um hospital prá outro, sozinha... foi muito difícil, é a mais difícil até agora né.

Tá bom, brigada.

\section{8: MARIA DO CARMO}

Então $M$, eu queria que você lembrasse, de uma situação que você viveu com o L., mas uma, um exemplo assim que foi bem legal.

Bem legal? (criança emite algum som) ai.... agora não sei (ri), sempre foi legal, né, com ele.

Não... mas... uma situação, um exemplo assim de uma vez, não precisa ser todas as situações, uma que você lembra assim, que você viveu com ele, que foi uma situação que você falou "Ah que legal".

Ah quando ele começou a andar, aí foi muito legal.

Foi essa? (É), agora eu queria o contrário, um, é ... uma situação, um exemplo de uma vez, alguma coisa que vocês viveram juntos que foi difícil, é... chato.

Foi difícil, foi deixar ele no hospital né, quando ele nasceu, aí nasceu com problema da tirícia, aí teve que ficar no hospital e eu fui embora.

\section{Problema do quê?}

Da ictirícia, que nasce bem amarelinho.

\section{Ah, Icterícia.}

Aí ele ficou no hospital, aí eu fiquei... aí foi chato.

Tá, é isso.

(risos) 
Bom, ôi M, (ôi) eu gostaria que cê me contasse uma situação, que se lembra, que cê viveu junto com a $B$ e que foi uma situação boa, legal.

Eu acho que a situação boa e legal foi o dia que ela nasceu... foi uma das fases mais legal e mais boa que eu tenho passado, foi isso, o dia que ela nasceu, a data do aniversário dela também, que a gente tem passado sempre juntos, ela tem 3 aninhos, então foi muito bom, todos os dias são legais né, são umas fases muito legal, mas acho que o mais legal foi o dia que ela nasceu mesmo (fala rindo) que nem, uma coisa muito boa foi essa.

Tá certo, e me diga uma coisa, eu queria o contrário agora, que cê me contasse uma situação que você se lembra que foi chata que foi difícil.

Que foi chata foi difícil? Foi quando ela tinha seis meses, eu tive que me separar dela deixei ela com a minha mãe e eu vim prá cá, deixei ela na Bahia, no norte, com a minha mãe e eu vim prá cá, fiquei três meses sem ela, foi uma situação bem difícil, foi três meses de ch... a nível de choro, e aí que com-assim, com a... os três meses que eu, que eu fui buscar ela, nossa ai foi bom, esse foi é... o mais difícil que eu tive, de lá prá cá foi tudo bem, só isso.

\section{Só isso...}

10: MARIA DOS REMÉDIOS (esta etapa foi realizada na residência da entrevistada)

$M$, eu queria que cê lembrasse uma história, contasse uma história, que cê lembrasse, que cê viveu com a $F$, que foi uma história legal, um exemplo.... que foi bom, assim... um momento legal.

Isso é difícil, né, que tipo de história?

Que cê desse um exemplo de um momento que cê viveu com a F. e que você lembra que

foi legal.

É que a criança, a F., é tão bebezinha, não tem ainda esse tipo de coisa com ela, que agora que ela tá desenvolvendo né, isso aí acho que não dá prá contar não...

Não tem nenhum momento que cê viveu (não) que foi legal?

Não, tem mais rotina mesmo né, agora que ela começou a falar, agora que tá começando, né (então, onde é... que tá a rotina?) (ri), (a rotina?)

Não precisa ser uma coisa grandiosa não, é... uma coisinha, que foi legal...

Que tipo de coisa assim (criança chama a mãe) ... ai acho que não tem não, viu?

Então vamos fazer o contrário tá? (ah) queria que você lembrasse de um episódio de um exemplo, de um momento que foi muito difícil que foi chato.

Chato? Bom o momento chato foi quando ela, ela tinha um furunquinho e eu não sabia, né, e... aí ela... pediram prá eu fazer uma compressa nela, né, (criança chama a mãe)... pediram prá fazer uma, uma compressa nela, e...ensinaram como que era, tal, que era com farinha, tipo uma gominha, né, aí eu... eu peguei (som de criança, fala rindo) eu não sabia, sabia que, dentro, é tipo assim, a massinha, por fora, parece que tá fria, tá morninha, mas por- por dentro... ali tá fervendo, então coloquei em cima assim, o médico pediu para colocar! e ai, eu coloquei tudo, quando eu fui abrir a fralda de novo o bumbum tava cheio de bolha, umas bolhas enormes, né, ai, nossa, me deu desespero, né, e ela até hoje tem essas marcas, vai ficar essas marquinhas, né, até avisava todo mundo para não contar prá ela né, que vai ficar ridícula, as marcas, uma coisa, assim, que eu não gostei, que eu sofri muito, né, porque ficou todo mundo olhando, depois me culparam: 'ai como que cê é burra' tal 'como você não foi ver isso?' Ah, acho que... só isso que aconteceu , assim de... né, que fiquei preocupada tal, só isso.

E agora cê lembraria de uma, um episódio que foi legal?

Ah, de coisa que foi legal, acho que não, viu (pausa). Ah, o que tá acontecendo de legal é ela falando, né, as palavrinhas assim, 'eu te amo' né... essas coisas, que criança faz, é... descobrindo o mundo né, que ela presta muita atenção, nas coisas, né, ela grava muito rápido, 
é... é... então ela, é, faz comentários, é, mamãe e papai tão trabalhando prá ganhar real sabe, prá comprar roupa, presente prá nós, esses tipo de coisa, isso eu acho legal, na criança, e... eu acho, acho que é só isso, ela tá aprendendo a viver né... só isso.....

Tá bom. (só isso?)

Era.

\section{1: MARIA MADALENA}

M, eu gostaria que cê me contasse uma situação, me desse um exemplo concreto, assim, de um momento, que você viveu, legal, com a J., que foi bom, que foi legal.

Que foi legal? Ah, foi o dia que ela nasceu né, foi muito legal mesmo, no começo ela começou a chorar e... quando ela nasceu, então na hora que ela me entregou ela, eu beijei, abracei, sabe, foi o momento mais feliz que eu tive, muito legal, isso.

Tá jóia, agora, o contrário, queria que cê me contasse, lembrasse de um exemplo, de uma situação... que você viveu com a J., que foi dificil, foi chato, foi difícil...

Ah, o dia em que ela ficou internada né, o dia que ela ficou internada, foi o... a pior coisa, porque a gente ficou dois, duas noites no hospital com ela no soro, é... ela num... não se lembrava não, se era, não sabia que era a gente, o torno do tombo que ela levou, isso foi o pior momento que a gente passou...

Tá, é isso.

\section{2: MARIA DA CONCEIÇÃO}

Então, é o seguinte, êh... eu gostaria de saber de uma lembrança sua, um exemplo de uma situação, de que você viveu com o M., que foi legal.

$\mathrm{Ai}$, acho que foi o primeiro instante de vida, acho que foi quando ele nasceu.

É? mas você não lembra de um exemplo...

Hum hum... depois também, o primeiro aniversário, quando ele falou pela primeira vez, ih são tantas e tantas, mas acho que a maior mesmo foi quando ele chamou 'mamãe' (Ah é?) Hum hum...

Tá certo, agora o con... cê ia dizer mais alguma coisa? (Não), agora o contrário, eu queria que cê lembrasse um exemplo, de uma situação, que cê viveu com o M. que foi difícil, que foi chata.

Ah, quando teve pneumonia (ri), acho que foi a... acho única também, foi a pior situação que eu já vivi com ele, foi quando teve pneumonia.

Não teve nenhuma outra situação que cê lembre?

Não, não, tudo foi tranqüilo.

Que cê perdeu a paciência... alguma coisa...

Não.

Então tá jóia, era isso, obrigada.

\section{3: MARIA IMACULADA}

M, eu queria que cê me... parasse um pouquinho e lembrasse de quando seu filhinho, crescendo e tudo mais... lembrasse de uma situação que você viveu com ele, que fosse uma situação que foi uma... lembrança boa, uma situação boa, legal, assim.

Legal, ai... ai, legal mesmo....

\section{Não precisa ser nada especial, um exemplo.}

Ah, prá mim quando ele começou se mexer mais né, começou ficar mais espertinho, ter dentinho, prá mim foi isso, né, que ele ficou mais espertinho, porque, por enquanto ele não tá andando né, aí prá mim, melhor assim, foi isso, porque ele quando era pequeno não dava nem prá gente ... aproveitar nada, só carrega, fica, fica meio serinha, agora não, tá mais sorridente tá uma criança mais ...sabe... 
Agora cê lembra de uma situação, assim, uma situação concreta, um exemplo assim de um dia?

De um dia? Foi num dia que ... queria acho que descer, caiu da...da cama, acho que ele chorou, sei lá, que aconteceu, ele queria pegar um brinquedo, e o brinquedo já tinha caído, aí ele, acho que ele foi ver o brinquedo, prá pegar, aí quando eu ví ele já tava... caidinho, assim, com as perninhas... dei... é... com as perninhas, assim, no chão já, aí, prá mim, assim... foi a melhor coisa que surgiu, né, porque é uma, sabe... uma felicidade, cê ver seu filho esperto né, apesar que cê leva um susto, né, porque pode machucar, mas prá mim...foi isso...

Então, agora é o contrário, eu queria que cê lembrasse de um exemplo, de uma situação, concreta, que foi difícil.

Difícil... ai, dor de ouvido, que eu ia em médico e médico e saia na conclusão, uma vez ele ficou internado por causa de dor de ouvido e acharam que era uma doença, hum...não sei muito bem o nome né, mas que... deixa a criança para...paralítica, né, ai... na hora que a médica falou, tudo bem, normal, quando fui ter a situação, da idéia da... o que a doença causa, ai eu fiquei des... desesperada, aí eu fiquei com ele um dia, ele ficou um dia internado, isolado, pensando que era essa doença, no fim, não era, era uma dor de ouvido, e no fim eu fiquei assustada à toa, e, os médicos, né, ma... prá mim foi o..., a melhor coisa assim, um momento meio assim ( $\mathrm{K}=\operatorname{assim}$ ) comovente assim, meio triste, e vamos, vamos seguir em frente.

Tá certo, obrigada.

14: MARIA APARECIDA (NÃO FOI POSSÍVEL REALIZAR A SEGUNDA ETAPA DESTA ENTREVISTA).

15: MARIA GORETH (NÃO FOI POSSÍVEL REALIZAR A SEGUNDA ETAPA DESTA ENTREVISTA). 